\title{
Paraguay: 2007 Article IV Consultation and Second and Third Reviews Under the Stand-By Arrangement-Staff Report; Public Information Notice and Press Release on the Executive Board Discussion; and Statement by the Executive Director for Paraguay.
}

Under Article IV of the IMF's Articles of Agreement, the IMF holds bilateral discussions with members, usually every year. In the context of a combined discussion of the 2007 Article IV consultation with Paraguay and second and third reviews under the Stand-By Arrangement, the following documents have been released and are included in this package:

- $\quad$ The staff report for the combined 2007 Article IV consultation and Second and Third Reviews Under the Stand-By Arrangement, prepared by a staff team of the IMF, following discussions that ended on May 15, 2007, with the officials of Paraguay on economic developments and policies. Based on information available at the time of these discussions, the staff report was completed on June 15,2007. The views expressed in the staff report are those of the staff team and do not necessarily reflect the views of the Executive Board of the IMF.

- $\quad$ A Public Information Notice (PIN) and Press Release, summarizing the views of the Executive Board as expressed during its June 29, 2007, discussion of the staff report on issues related to the Article IV consultation and the IMF arrangement, respectively.

- $\quad$ A statement by the Executive Director for Paraguay.

The documents listed below have been or will be separately released.

Letter of Intent sent to the IMF by the authorities of Paraguay*

Memorandum of Economic and Financial Policies by the authorities of Paraguay*

Technical Memorandum of Understanding*

*Also included in Staff Report

The policy of publication of staff reports and other documents allows for the deletion of market-sensitive information.

\author{
Copies of this report are available to the public from \\ International Monetary Fund $\bullet$ Publication Services \\ $70019^{\text {th }}$ Street, N.W. • Washington, D.C. 20431 \\ Telephone: (202) 623-7430 • Telefax: (202) 623-7201 \\ E-mail: publications@imf.org • Internet: http://www.imf.org
}

Price: $\$ 18.00$ a copy

\section{International Monetary Fund Washington, D.C.}





\title{
INTERNATIONAL MONETARY FUND
}

\section{PARAGUAY \\ Staff Report for the 2007 Article IV Consultation and Second and Third Reviews Under the Stand-By Arrangement}

\author{
Prepared by the Western Hemisphere Department \\ (In consultation with other departments) \\ Approved by José Fajgenbaum and Matthew Fisher
}

June 15, 2007

- 2004 Article IV Consultation. The last consultation was completed on July 30, 2004. Directors commended the authorities for stabilizing the economy and the resumption of growth. They encouraged the authorities to strengthen their structural reform efforts to reduce vulnerabilities.

- 2007 Article IV Consultation. This year's discussions focused on policies that would help to address the main problem faced by the economy over a long period, namely, endemic low growth, which has led to declining living standards and widespread poverty. The staff (with participation of the World Bank and IDB staffs) prepared selected issues papers on reform areas necessary to entrench macroeconomic stability, reinvigorate growth, and reduce poverty.

- Fund Relations. A 27-month Stand-By Arrangement (SBA) was approved on May 31, 2006 (for SDR 65 million or 65 percent of quota). The first review was completed on a lapse of time basis on September 29, 2006. The authorities are treating the arrangement as precautionary, and Paraguay has no outstanding Fund credit. Paraguay maintains a floating exchange rate regime with occasional interventions to achieve reserve targets and smooth out bulky and/or seasonal transactions. It has accepted the obligations under Article VIII, Section 2 (a), 3, and 4 of the Fund's Articles of Agreement. The exchange system is free of restrictions on the making of payments and transfers for current international transactions.

- Second and Third SBA Reviews. The two reviews are combined because it took longer than expected to agree on financial policies for 2007. All performance criteria and all but three structural benchmarks were observed through end-April 2007. The economy is estimated to have grown by 4 percent and headline inflation rose to $12 \frac{1}{2}$ percent in 2006 , overshooting the 7 percent program target mainly due to supply shocks.

- 2007 Program. Macroeconomic objectives for 2007 are broadly similar to those presented at the time of program approval in May 2006, including real GDP growth of 4-5 percent and a core inflation rate of 5 percent. Fiscal policy will aim at maintaining overall balance. The structural reform agenda addresses issues identified during the consultation discussions, aiming at reducing impediments to growth and alleviating poverty.

- Discussions. These took place during November 29-December 13, 2006 and March 7-13, 2007 in Asunción; and April 11-13, 2007 in Washington. The mission met with President Duarte-Frutos, VicePresident Castiglioni, Finance Minister Bergen, Central Bank President Rojas, former Central Bank President Pérez dos Santos, the Social and Economic Cabinets, Deputy Finance Minister von Horoch, senior officials, representatives of the international, business and banking communities, and members of Congress and civil society. The staff included A. Santos (head), F. Frantischek, M. Mlachila, T. Roy, B. Monfort (all WHD), P. Breuer (PDR), and J. Gasha (MCM). The mission was assisted by L. Duran-Downing, the Fund's senior resident representative. Mr. Singh (WHD) attended the policy discussions during December 4-5, 2006. Mr. Salgueiro (OED) also participated in the discussions. 


\section{List of Acronyms}

\begin{tabular}{|c|c|}
\hline ANDE & National Electricity Company \\
\hline $\mathrm{BCP}$ & Central Bank of Paraguay \\
\hline BCPEBS & Basel Core Principles of Effective Banking Supervision \\
\hline $\mathrm{BNF}$ & National Development Bank \\
\hline CADEF & Ranking of Financial Institutions \\
\hline CAR & Capital Adequacy Ratio \\
\hline CCT & Conditional Cash Transfer \\
\hline COPACO & Public Telephone Company \\
\hline DSA & Debt Sustainability Analysis \\
\hline ESSAP & Public Water and Sewage Company \\
\hline FAD & Fiscal Affairs Department \\
\hline FSAP & Financial Sector Assessment Program \\
\hline GDP & Gross Domestic Product \\
\hline GNFS & Good and Nonfactor Services \\
\hline IDB & Inter-American Development Bank \\
\hline INC & National Cement Company \\
\hline INCOOP & National Institute of Cooperatives \\
\hline IPS & Social Security System \\
\hline LEG & Legal Department \\
\hline LOI & Letter of Intent \\
\hline LRM & Central Bank Bills \\
\hline MCM & Monetary and Capital Markets Department \\
\hline MEFP & Memorandum of Economic and Financial Policies \\
\hline NDA & Net Domestic Assets \\
\hline NFPS & Non-Financial Public Sector \\
\hline NIR & Net International Reserves \\
\hline NPL & Nonperforming Loans \\
\hline PC & Performance Criteria \\
\hline PDR & Policy Development and Review Department \\
\hline PFM & Public Financial Management \\
\hline PETROPAR & Public Petroleum Company \\
\hline ROSC & Report on the Observance of Standards and Codes \\
\hline SAS & Undersecretary of Social Action \\
\hline SB & Structural Benchmark \\
\hline SBA & Stand-By Arrangement \\
\hline SDR & Special Drawing Rights \\
\hline TMU & Technical Memorandum of Understanding \\
\hline VAT & Value Added Tax \\
\hline WB & World Bank \\
\hline WHD & Western Hemisphere Department \\
\hline
\end{tabular}




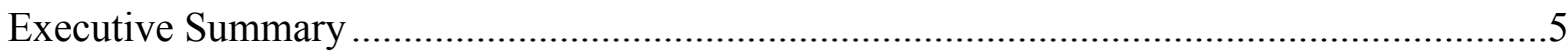

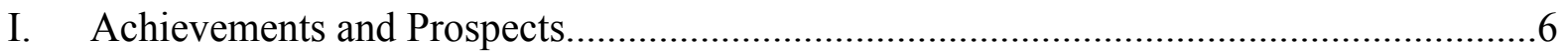

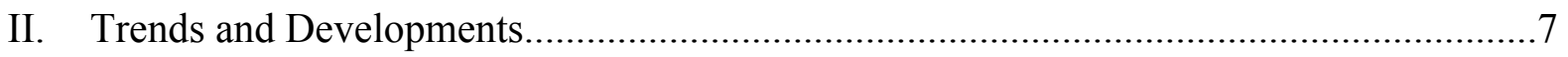

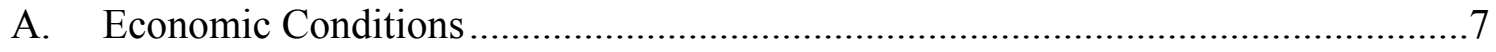

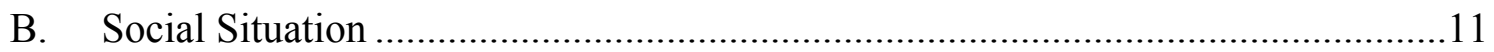

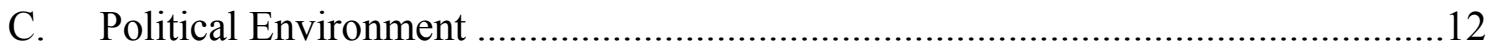

III. Performance Under the Program ..................................................................... 12

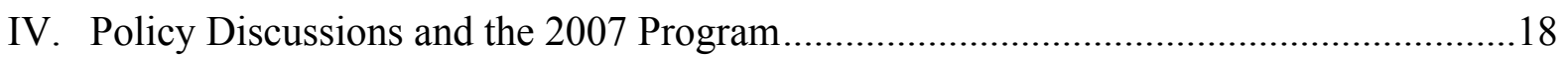

A. Strengthening Macroeconomic Management ................................................. 18

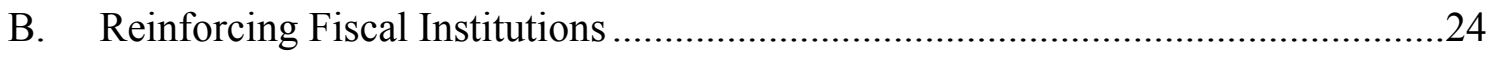

C. Tackling Financial System Weaknesses ..............................................................26

D. Developing a Pro-Growth Policy Agenda .........................................................27

E. Towards and Effective Poverty Reduction Policy .............................................28

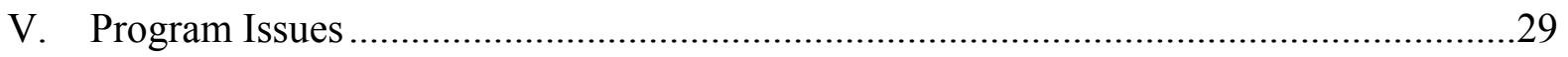

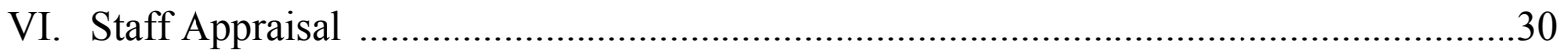

\section{Text Boxes}

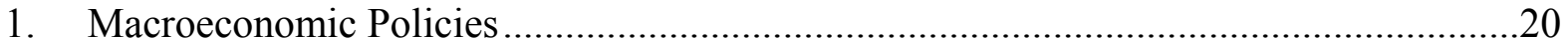

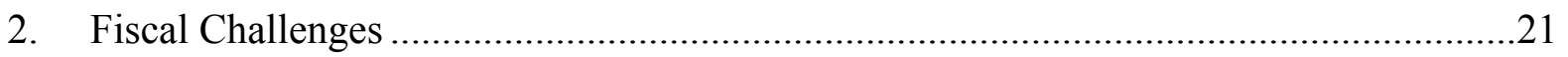

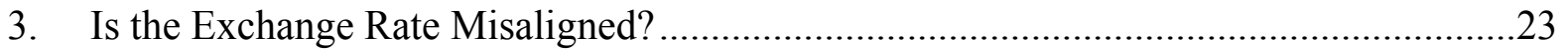

\section{Tables}

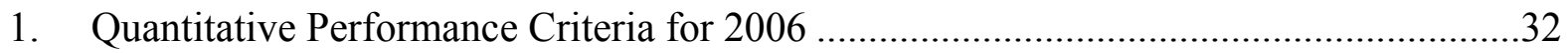

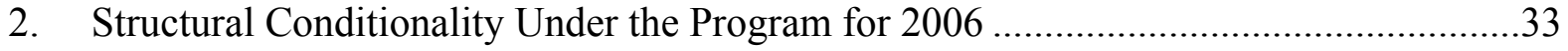

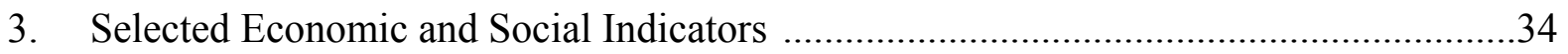

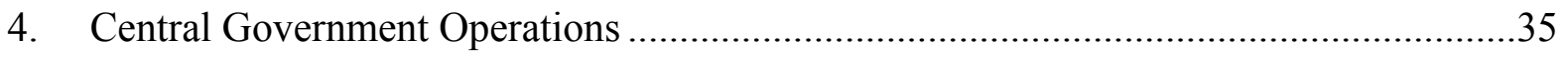

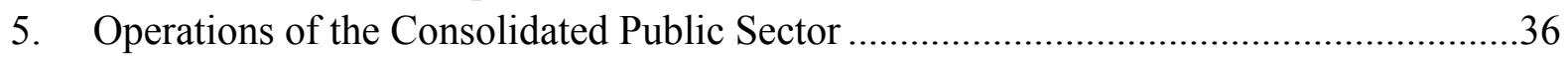

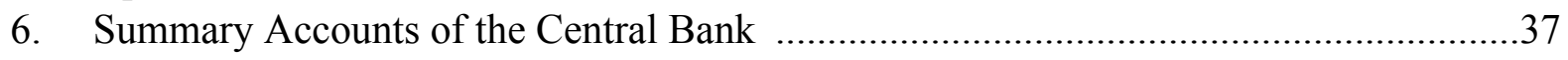

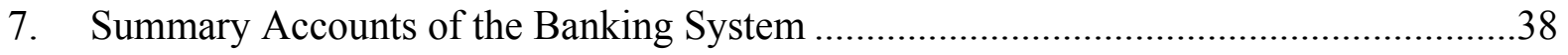

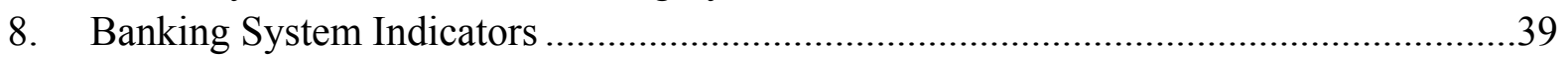

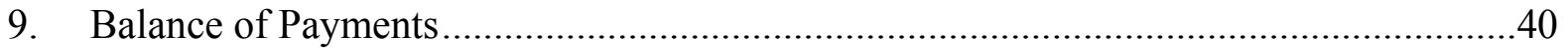

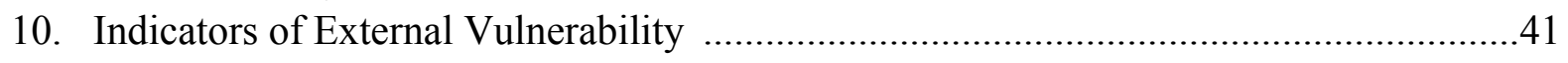


11. Schedule of Reviews and Purchases ......................................................................42

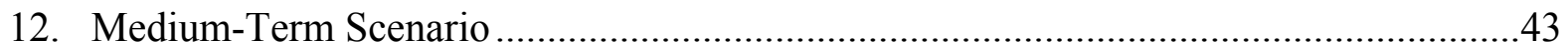

\section{Figures}

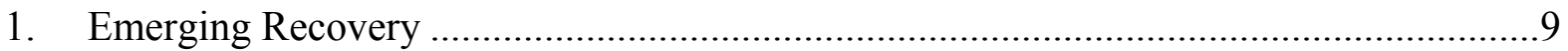

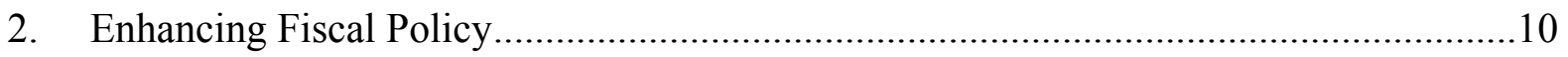

3. Coping with the Monetary Effects of Reserves Inflows ............................................13

4. Strengthening of the Banking and Financial Systems .............................................. 14

5. Balance of Payments Developments........................................................................ 17

\section{Appendices}

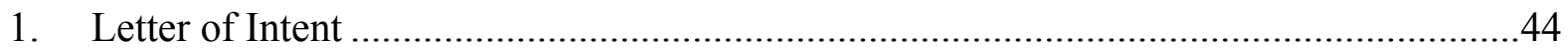

2. Memorandum of Economic and Financial Policies of the Government of

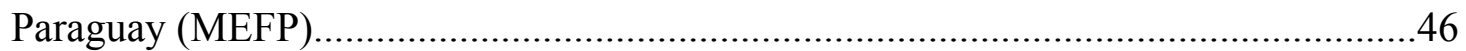

3. Technical Memorandum of Understanding (TMU) ...................................................56

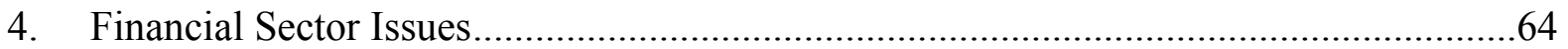

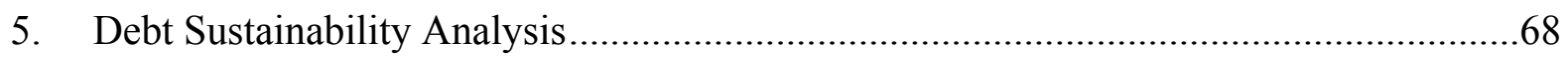

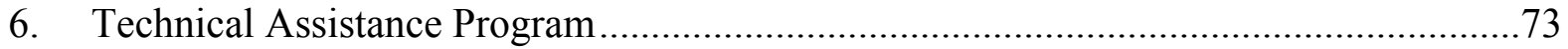

7. Relations with International Financial Institutions ................................................76

\section{Annexes}

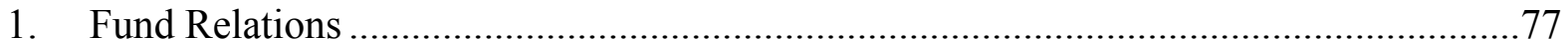

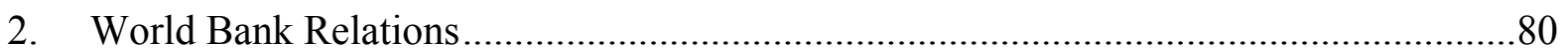

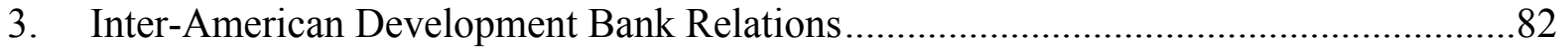

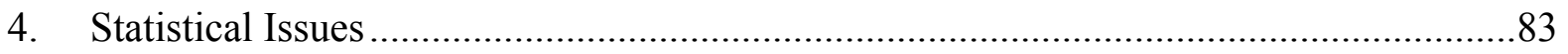

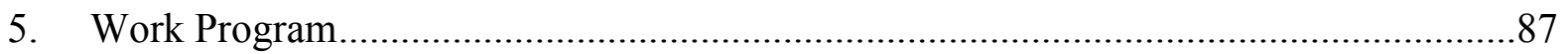




\section{EXECUTIVE SUMMARY}

\section{Achievements and Performance}

- Macroeconomic outcomes continue to be strong. Since the approval of the previous SBA in 2003, growth rebounded to almost twice its long-term average, per capita income has surged to its highest level in 8 years after a prolonged decline, and extreme poverty was reduced by almost one third. This impressive performance was underpinned by the re-establishment of fiscal and monetary discipline, which reduced the consolidated public debt-to-GDP ratio by one half, contained inflation, strengthened the guarani by over one third, and raised international reserves to a historical peak.

- $\quad$ The current program remains broadly on track. All quantitative and structural performance criteria and all but three structural benchmarks through end-April 2007 were observed. The economy grew faster than expected in 2006 and continued expanding in early 2007. However, inflation was higher than programmed in the latter part of 2006 due to supply shocks that began to unwind in early 2007. Fiscal discipline was preserved despite pressures. Large foreign exchange inflows continued, leading to record high reserves and a significant appreciation of the currency.

\section{Challenges and Appraisal}

- $\quad$ Raising growth on a sustainable basis and addressing widespread poverty are the main challenges. Discussions with the authorities centered around five reform areas:

(i) strengthening macroeconomic management; (ii) reinforcing fiscal institutions;

(iii) tackling financial weaknesses; (iv) developing a pro-growth policy agenda; and

(v) designing an effective poverty reduction policy.

- The macroeconomic program for 2007 aims at raising growth and reducing inflation. The authorities will preserve fiscal discipline and pursue a prudent monetary stance consistent with a core inflation objective of 5 percent. The external outlook remains positive, with international reserves increasing faster than projected.

- The structural agenda for 2007 aims at deepening reforms. The program includes a wide range of reforms to address the problem areas identified during the consultation discussions. Owing to changes in the leadership of the Central Bank and a complex political environment, some reforms had to be re-phased, including the strategy to strengthen the financial position of the Central Bank, the amendments to the banking law, and improvements of the banking regulatory and supervisory frameworks.

- Staff recommends that the next Article IV consultation continues within the 24-month cycle, and supports completion of the second and third SBA reviews. 


\section{AChievements And Prospects}

1. Accomplishments. Following a decade of stagnation and instability and a quarter century of declining living standards, Paraguay has experienced some of the best macroeconomic outcomes in recent years. After the 2002 financial crisis, growth rebounded to almost twice its long-term average, per capita income surged to its highest level in 8 years, and extreme poverty was reduced by almost one third. An appropriate fiscal adjustment effort helped

\begin{tabular}{|lcc|}
\hline \multicolumn{3}{|c|}{ Paraguay: Long-Term Performance } \\
\hline Real GDP growth (\%) & $1996-2002$ & $2003-2006$ \\
Per capita income (th \$) 1/ & 0.2 & 3.6 \\
Extreme poverty ratio (\%) 1/ & 0.9 & 1.5 \\
Inflation (\%) & 21.7 & 15.5 \\
Consolidated public debt (\% GDP) 1/ & 9.4 & 8.6 \\
International reserves (bn \$) 1/ & 74.0 & 33.9 \\
\hline Sources: Paraguayan authorities. 1/ End of period. \\
\hline
\end{tabular}
regularize payments, eliminate arrears, and reduce the debt-to-GDP ratio by one half. This effort was accompanied by a cautious monetary policy, which limited core inflation, strengthened the guarani and tripled international reserves.

2. Reforms. Since 2003, the country implemented a number of initiatives aimed at modernizing the economy, reducing impediments to growth, and improving deep-rooted governance issues. The reforms include: (i) the fiscal adjustment law (which introduced the personal income tax, eliminated tax exemptions and broadened the tax base); (ii) the customs code (which strengthened the autonomy of customs); (iii) the banking resolution law (which set up the deposit guarantee fund); (iv) the public pension fund law (which introduced a parametric reform on this fund); and (v) the second tier-public banking law (which created the Financial Development Agency to intermediate long-term funds provided by donors). Evidence of improved governance comes from a sharp improvement in tax administration and revenue collections, a rapid recovery of non-performing loans at the National Development Bank (BNF), and the enactment of a strict procurement law. ${ }^{1}$

3. Outlook. International and regional prospects remain favorable, facilitating an expansion of Paraguayan exports and supporting the ongoing economic recovery. An end to a three-year drought is expected to be translated into good crops, especially soybeans.

4. Risks. The main external risk is a sudden change in the favorable global and regional environment due to an abrupt slowdown in U.S. growth, tighter conditions in financial markets, and a disorderly unwinding of global imbalances. The balance of payments remains vulnerable to risks affecting the burgeoning beef export sector (such as an outbreak of footand-mouth disease) or, more generally, from the spillover of shocks from the much larger neighboring countries. The most serious domestic risk is the possibility of political stalemate and policy impasse in the pre-electoral period. Presidential elections are scheduled for April 2008.

\footnotetext{
${ }^{1}$ In the latest ranking of the corruption perception index compiled by Transparency International, Paraguay moved up more than 30 positions (the largest improvement) from position 144 (out of 159 countries) in 2005 to 111 (out of 163) in 2006.
} 


\section{TRends AND DeVelopMents}

\section{A. Economic Conditions}

5. Growth. The expansion that began in 2003 continued through 2006, as real GDP rose about 4 percent, surpassing the program objective of $3 \frac{1}{2}$ percent. On the supply side, services and manufacturing rose significantly, while agricultural output began to recover, as the effects of the prolonged drought waned. On the demand side, growth was driven by a dynamic export sector (particularly beef) and an increase in private investment (especially in telecommunications). Economic activity remained buoyant in the first quarter of 2007, driven by good crops.

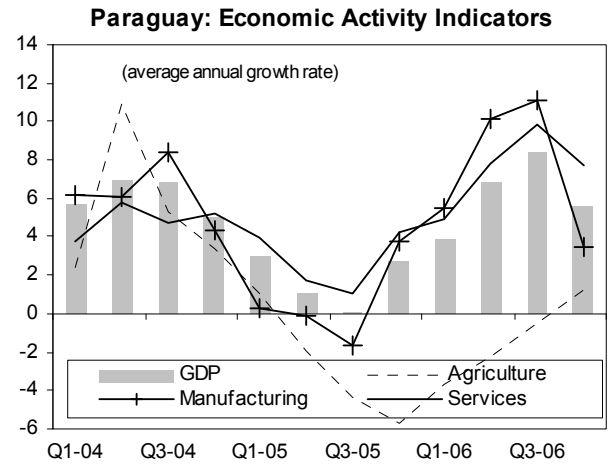

6. Inflation. It has been quite volatile given the economy's high vulnerability to external shocks. ${ }^{2}$ Efforts to reduce inflation continued in 2006 with mixed results. While core inflation (excluding fruits and vegetables) fell from 10 percent in 2005 to 7 percent (in line with the program objective), headline inflation increased from 10 percent in 2005 to $12 \frac{1}{2}$ percent. Two shortterm factors explain this increase: (i) stricter application of sanitary controls on imports of vegetables, which reduced supplies and increased vegetable prices by almost 100 percent; and (ii) increased access to beef markets abroad, which

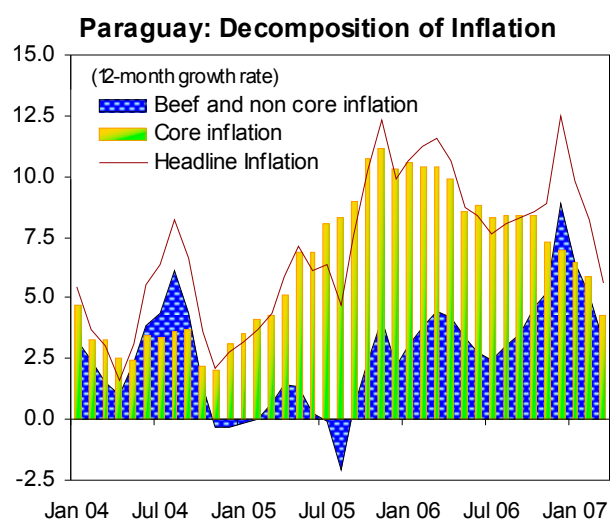
raised domestic beef prices by over 30 percent. The supply shocks unwound in the first five months of 2007 (as sanitary controls were relaxed and domestic beef supplies increased in response to higher prices), and the 12-month rate of headline inflation fell to about 7 percent in May 2007.

7. Debt Sustainability. The consolidated public debt-to-GDP ratio increased almost fourfold in the second half of the 1990's and reached over 70 percent by 2002, owing to large fiscal imbalances, a depressed economy and a depreciated currency. One of the major accomplishments of the current administration has been to put the public finances on a sound footing and the debt-to-GDP ratio on a declining path through an orderly

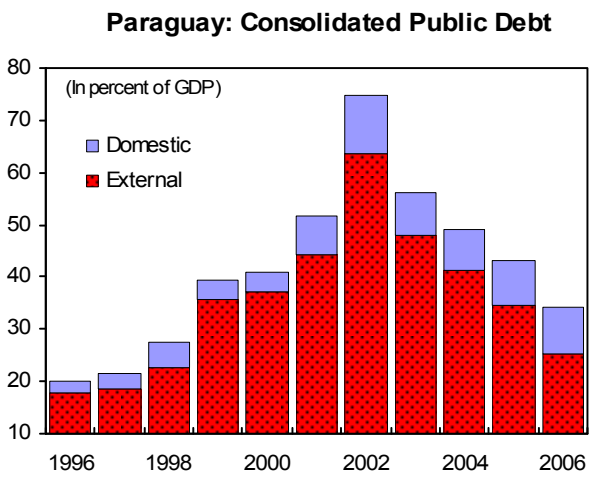

\footnotetext{
${ }^{2}$ The highest inflation rate in a calendar year in the last 10 years was about 15 percent in 2002.
} 
process of adjustment, assisted by a strengthening of the economy and the guarani. Over the last four years, the consolidated public debt-to-GDP ratio fell one half to about 35 percent in 2006.

8. Fiscal Performance. The public finances improved considerably in the last few years, mainly through higher tax collections and efforts to rein in current spending. The overall public balance showed a small surplus in 2006 (0.1 percent of GDP), compared with a balanced position envisaged in the program. Tax collections continued to be buoyant and current expenditures remained under control by the implementation of a strict financial plan, the freezing of new positions, and some under-execution of capital expenditures. Fiscal discipline continued during the first quarter of 2007.

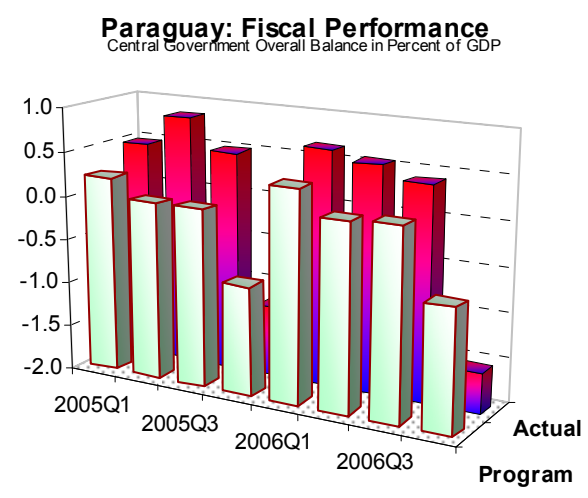

9. Monetary Conditions. The main challenge after the 2002 crisis has been the return of large foreign exchange inflows and their management. Improvements in the external position and the Central Bank's purchases of surplus foreign exchange from the binational hydroelectric plants ${ }^{3}$ led to an increase in international reserve of US\$400 million in 2006 ( 85 percent of currency), despite an 18 percent appreciation of the guarani against the U.S. dollar. Large placements of Central Bank bills (LRMs) were necessary to contain the increase in currency to some 15 percent in 2006.

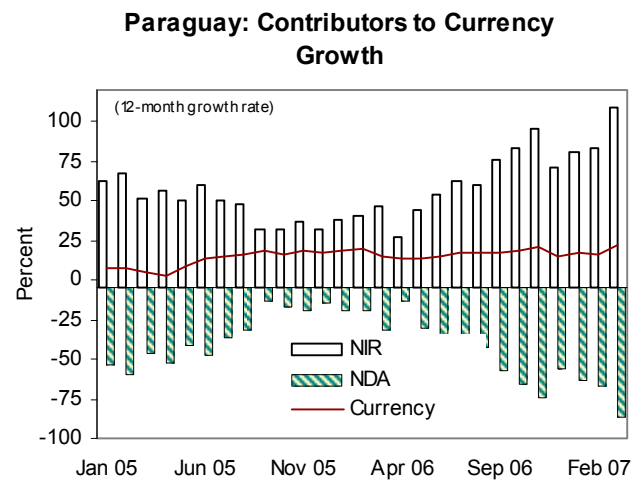
The strong external position continued during the first five months of 2007, and the Central Bank raised its pace of foreign exchange intervention to avoid an abrupt appreciation of the currency. The main source of the foreign exchange inflows switched from binational hydroelectric plants in 2006 to the private sector in 2007 . However, as intervention was only sterilized in part, currency growth rose to over 20 percent by end-May 2007, creating a potential liquidity overhang.

\footnotetext{
${ }^{3}$ Paraguay signed bilateral treaties with Brazil and Argentina in the 1970's to create two independent binational hydroelectric plants (Itaipú and Yacyretá) which exploit the Paraná river at different border points. As part of the treaties, each binational entity pays royalties to the government of Paraguay. In addition, Paraguay sells back most of its energy to the neighboring countries.
} 
Figure 1. Paraguay: Emerging Recovery

Growth accelerated in 2006, led by higher exports and domestic demand, while a relatively higher inflation rate was the result mainly of supply shocks.

A more dynamic export and domestic demand supported an acceleration in real GDP growth.

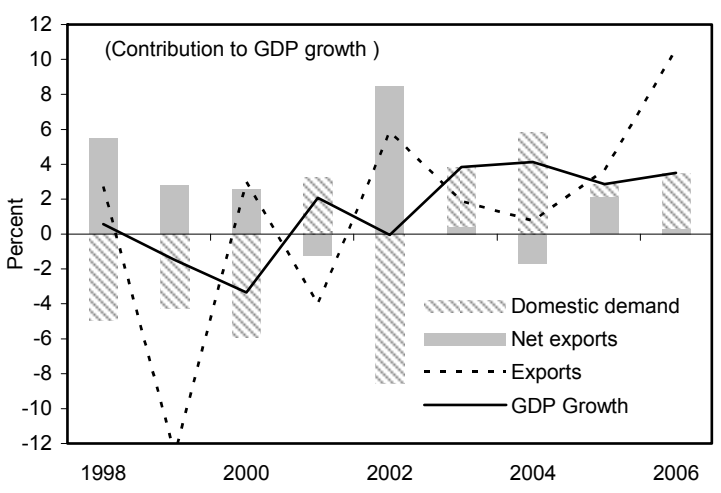

... and a boom in livestock production, which has now started to level off.

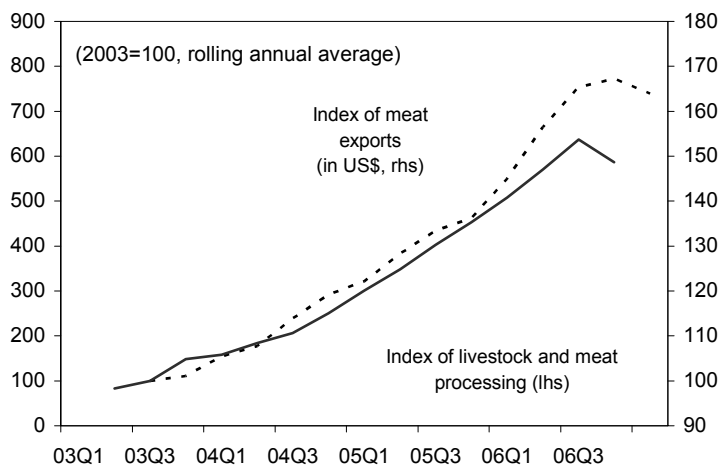

Inflation has returned within the target band after shooting up at the end of 2006...

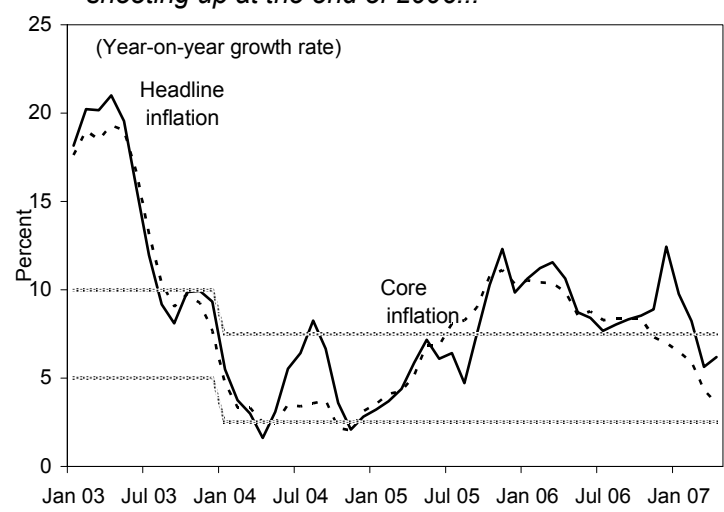

Sources: Paraguayan authorities and Fund staff estimates.
Growth has been driven by the service sector, especially communication and transport...

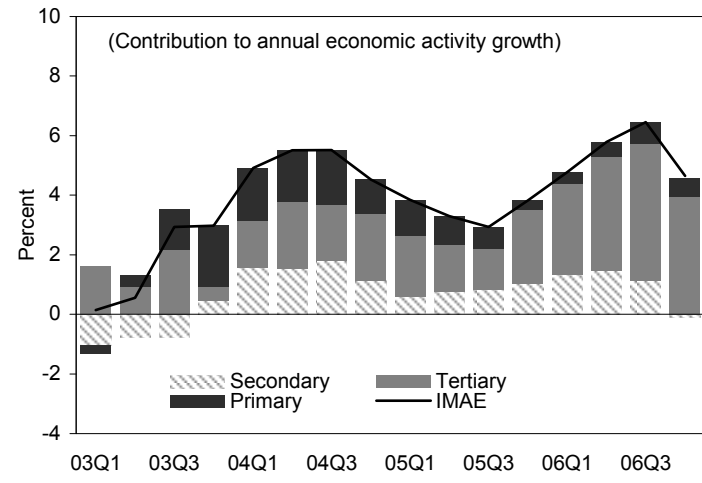

Agriculture production and export crops are recovering after the drought of last year.

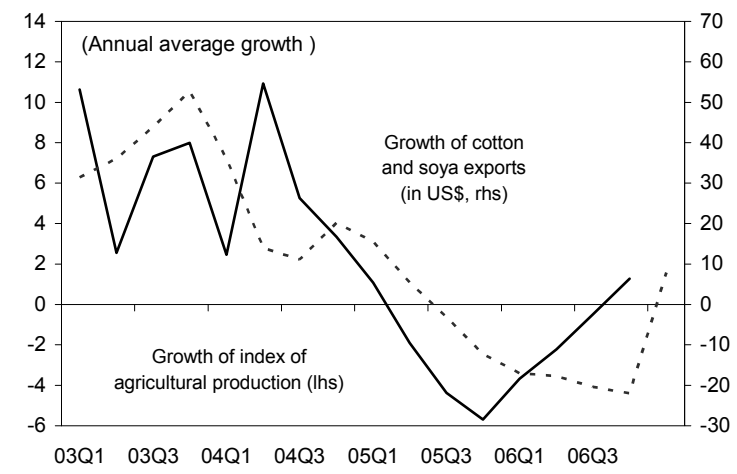

... mostly on account of adverse supply shocks, notwithstanding the moderation of import prices.

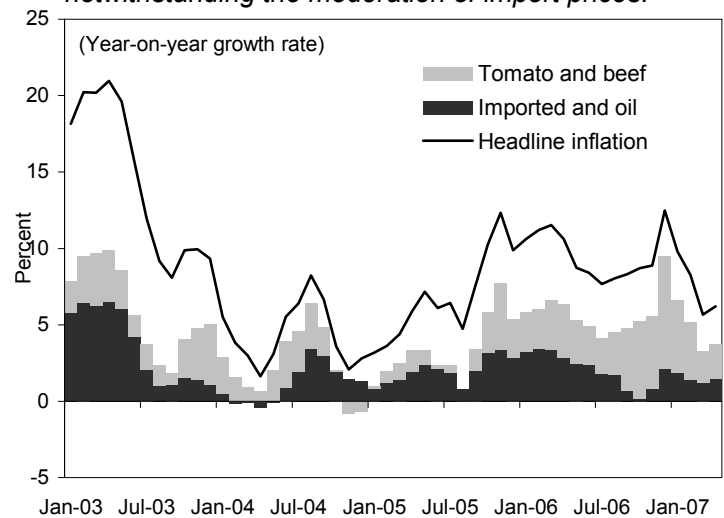


Figure 2. Paraguay: Enhancing Fiscal Policy

Significant progress has been made in addressing fiscal imbalances. The challenge is to preserve fiscal sustainability and create the fiscal space to meet essential social and infrastructure spending needs.

Despite unrealistic budgets, ...

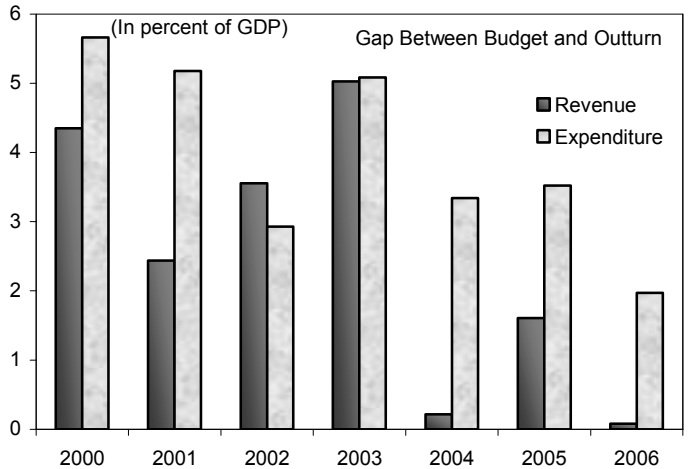

Supported by improved tax collection...

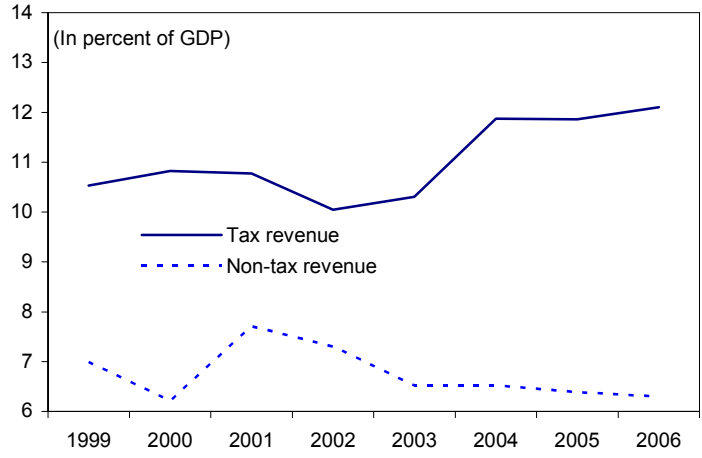

But with tax revenue growth leveling off and renewed current spending pressures ...

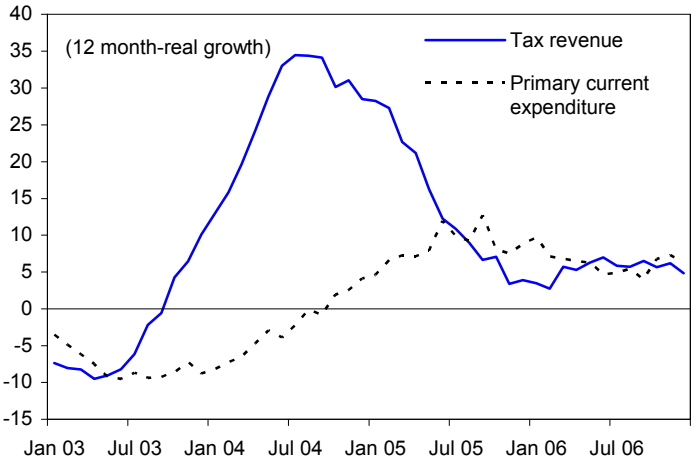

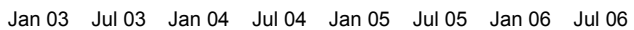

Sources: Paraguayan Authorities and Fund staff estimates. ...fiscal stance has been prudent in recent years.

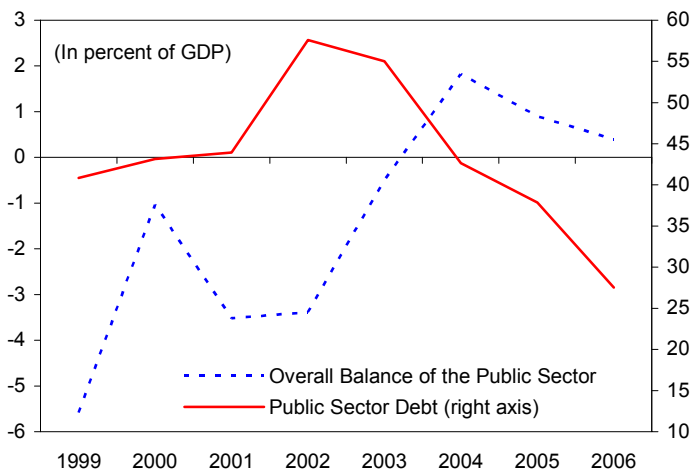

...and by efforts to contain current spending below appropriated amounts.

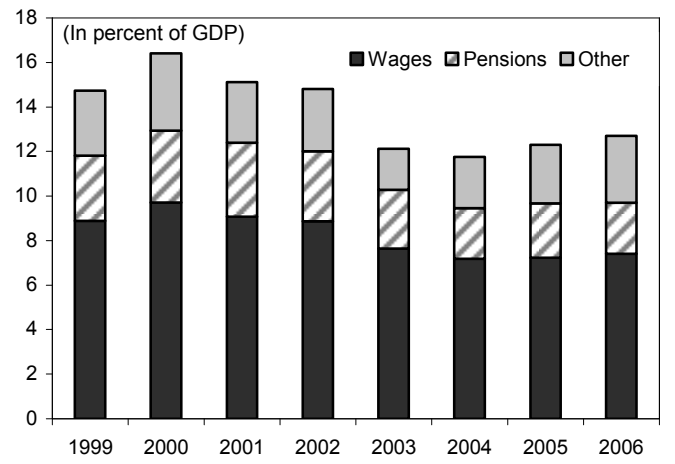

...the challenge is to step up revenue mobilization and reduce budget rigidities.

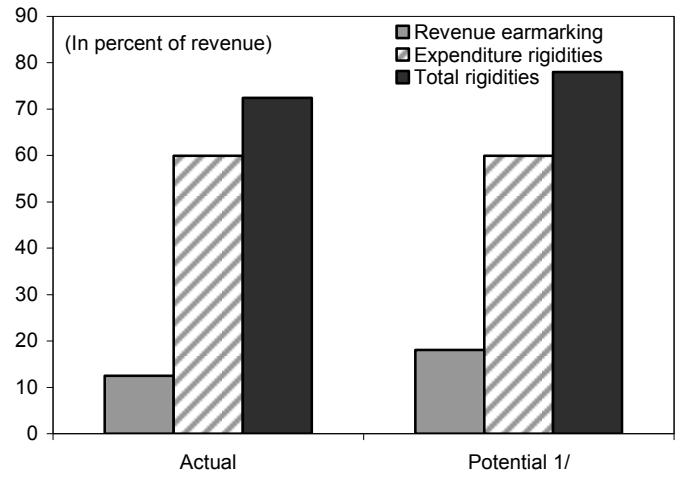

1/ With full implementation of royalties earmarking law.

60 40 30 
10. Financial Intermediation. Banks have resumed lending activities taking advantage of improved macroeconomic conditions after the credit crunch of 2002. Credit to the private sector grew by 18 percent in 2006 , reaching $13 \frac{1}{2}$ percent of GDP. Improved market confidence and the stronger guarani have led to a marked decline in dollarization from over 65 percent of assets and liabilities in 2002 to less than 50 percent in 2006.

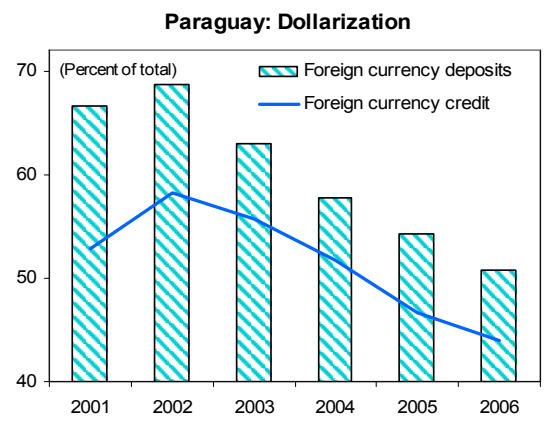

11. Banking Soundness. Banks have strengthened their financial position over the last few years, with capital adequacy ratios at 20 percent - well above the regulatory minimum of 10 percent. Even the National Development Bank (BNF), one of the weakest banks after the 2002 crisis, regained its solvency in 2006. However, the situation still needs to be carefully monitored as accounting practices and regulations remain weak. Non-performing loans significantly declined to 5 percent in 2006, profitability recovered, and

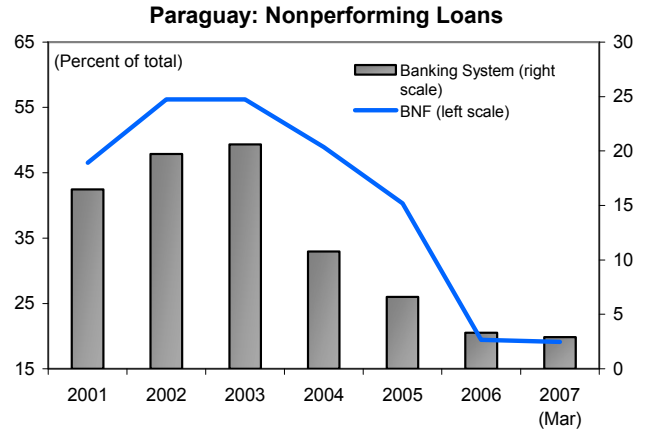
liquidity ratios remained comfortable.

12. External Sector. The external position has improved greatly in recent years, supported by a benign international and regional environment and a reflow of previous capital flight. This allowed the Central Bank to raise international reserves from US $\$ 0.6$ billion at end-2002 to over US\$2 billion by end-May 2007, while the guarani strengthened by 35 percent against the U.S. dollar. During 2006, the overall external position improved further, despite a deterioration of the current account (due to a surge in import demand), as the capital account remained strong.

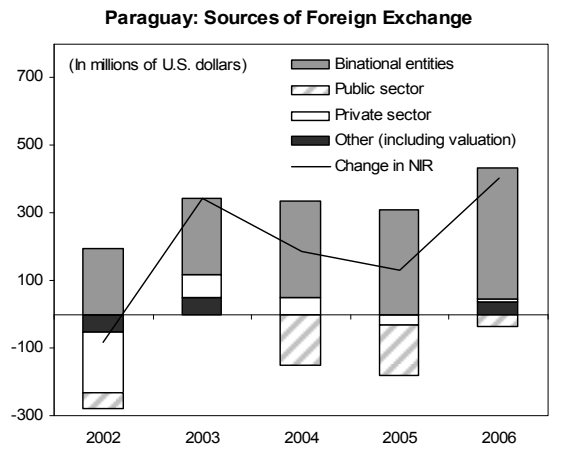
Binational hydroelectric plants were a driving force in generating a large foreign exchange surplus. Foreign exchange inflows continued in early 2007.

\section{B. Social Situation}

13. Status. Following a sharp rise during the period of economic stagnation, the overall poverty index decreased from almost 50 percent of the population in 2002 to less than 40 percent in 2005. Social investment increased substantially during the past ten years, helping achieve significant progress in education - with illiteracy rates falling from almost 10 percent in 1995 to 4 percent in

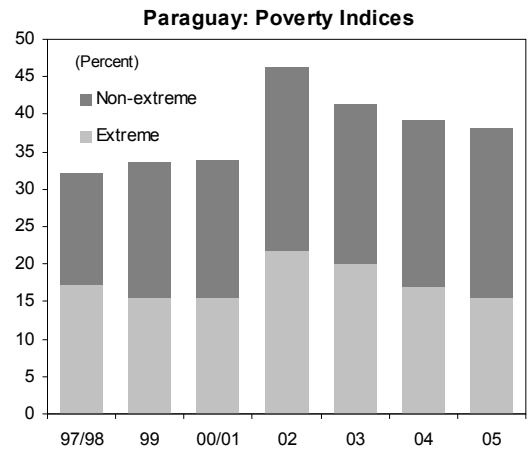


2005-and improving health infrastructure. However, social spending (at about 10 percent of GDP), is still somewhat low by Latin American standards, limiting health services coverage, particularly in rural areas.

\section{Political Environment}

14. Elections. Preparations have started in earnest for the April 2008 general elections. Nomination of presidential candidates by their parties is expected in late 2007. Congress, which is controlled by the opposition, is likely to intensify its opposition to government initiatives as has happened over the past year. ${ }^{4}$ Expenditure pressures may increase towards the end of the year given the pre-electoral period. Nonetheless, there are demands from the business community to ensure that the economy is "insulated" from undue political pressures.

\section{Performance Under the Program}

15. Implementation. The program remains broadly on track despite the start of the electoral period as the authorities pursued sound policies, and the external environment remained favorable. This section reports on performance under the second review (i.e., endSeptember 2006 targets) and the third review (i.e., end-December 2006 targets). The reviews have been delayed as the new leadership of the Central Bank needed time to reassess the envisaged reforms in the financial sector. ${ }^{5}$

16. Macroeconomic Program 2006. The overall fiscal targets for 2006 were observed as a solid revenue performance continued, notwithstanding strong expenditure pressures in the last quarter of 2006. The public wage bill target for 2006 was also met despite Congressional approval in late 2006 of a supplementary budget (which increased the wage bill by almost 0.2 percent of GDP), thereby raising expenditure pressures and budget rigidities for 2007 . The credit and international reserve targets for 2006 were observed with considerable margins as the Central Bank sterilized the bulk of large foreign exchange inflows. Monetary policy was assisted by the strong fiscal policy and efforts to reduce the losses of the Central

\footnotetext{
${ }^{4}$ In particular, Congress: (i) overrode the Presidential veto to the law that delayed the introduction of the personal income tax to 2007 with a 2/3 majority in September 2006 (while this move will not have a significant impact on tax collections in the short-term, it sends a negative signal to tax payers); (ii) did not approve in 2006 an IDB program loan for US\$30 million with favorable terms (which effectively rolled over IDB amortizations); and (iii) approved in September 2006 additional spending that increased the wage bill by almost 0.2 percent of GDP.

${ }^{5}$ Former Central Bank President Monica Perez dos Santos resigned in mid-February 2007. Mr. German Rojas (former BNF President) was confirmed by Congress as President of the Central Bank in late March 2007. In addition, Congress also appointed three other members of the Central Bank Board, whose positions had been vacant for almost a year.
} 
Figure 3. Paraguay: Coping with the Monetary Effects of Reserves Inflows

The strong balance of payments has complicated monetary management. The BCP has so far taken a balanced stance, through a mixture of nominal exchange rate appreciation and reserves accumulation with sterilization. However, currency growth continues to be high and could become a source of inflationary pressures.

Currency growth was recently again driven by strong NIR growth...

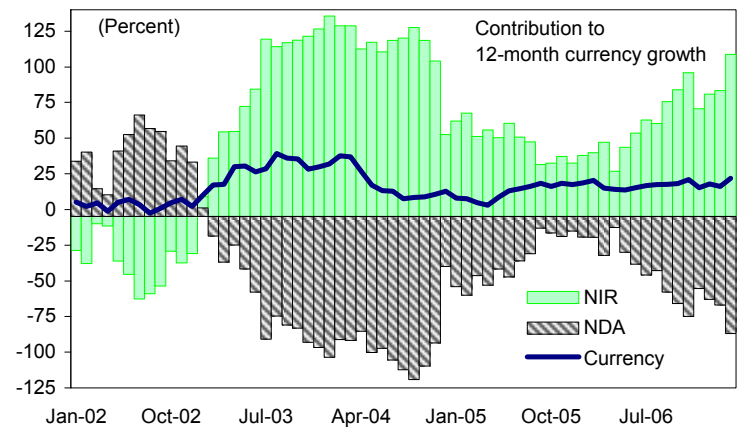

...nudging up interest rates on LRMs until recently.

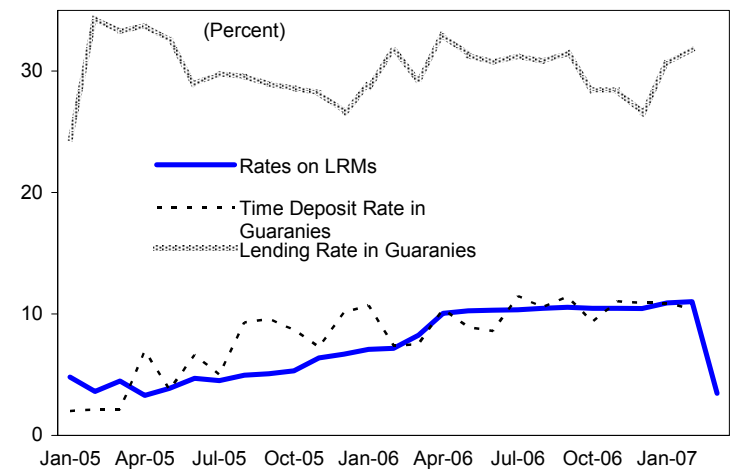

...helped dissipate inflationary pressures, although volatile food items pushed up headline inflation in late 2006...

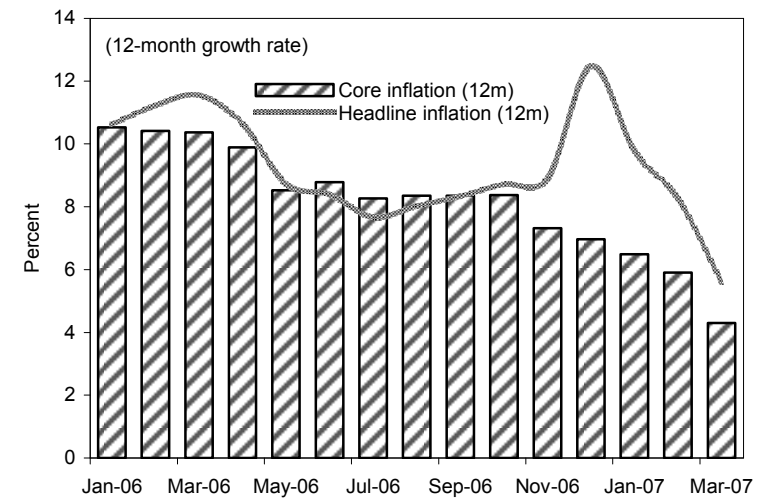

...while the BCP sterilized through issuance of $L R M s .$.

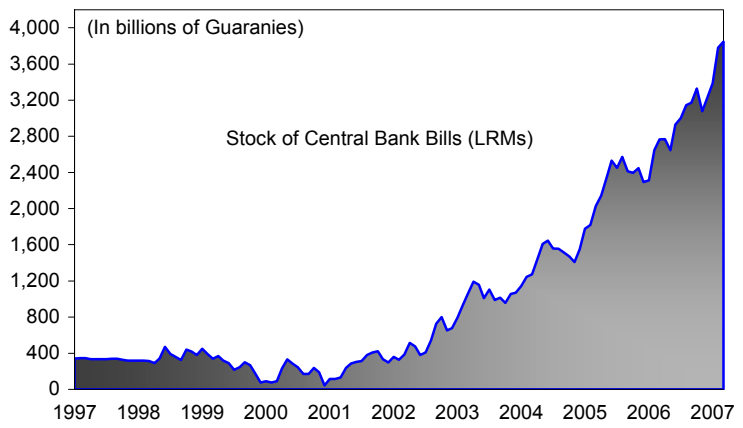

A strong guarani both against the dollar and in real terms...

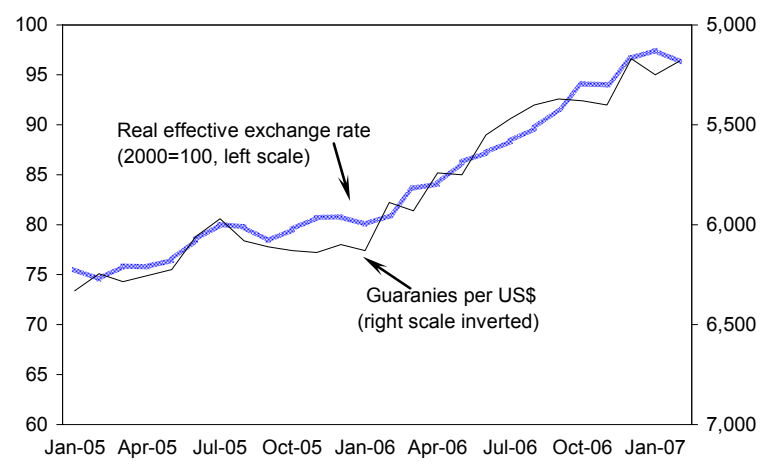

... and growth in real monetary aggregates remains high.

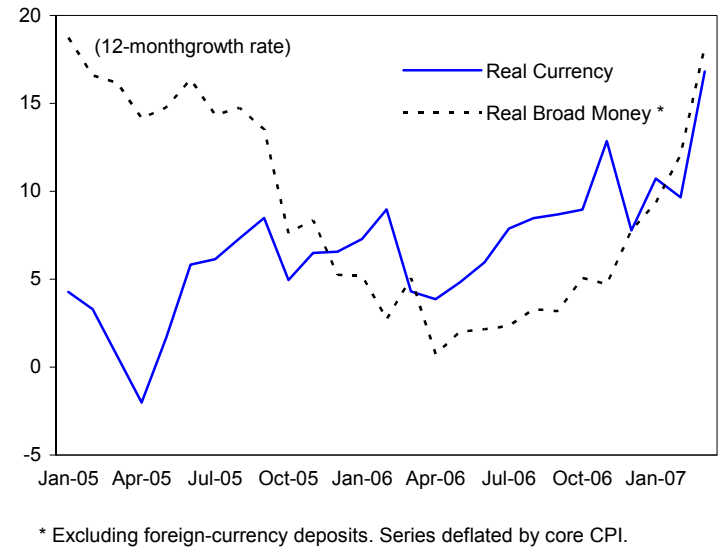

Sources: Paraguayan Authorities and Fund staff estimates. 
Figure 4. Paraguay: Strenghtening the Banking and Financial Systems

The financial system is recovering after several years of financial distress that dramatically reduced the size of the banking system. The macroeconomic stability of recent years provides a window of opportunity to address key remaining vulnerabilities that would be an obstacle to growth.

In the context of sustained macroeconomic stability, financial intermediation is gradually recovering...

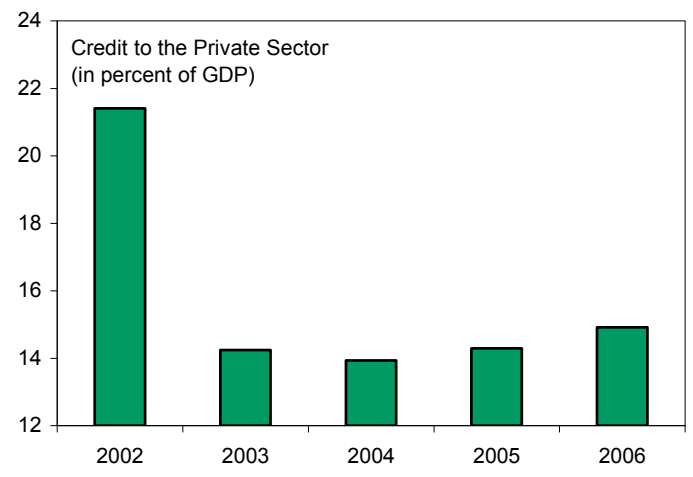

... and the maturity of assets and liabilities has lengthened...

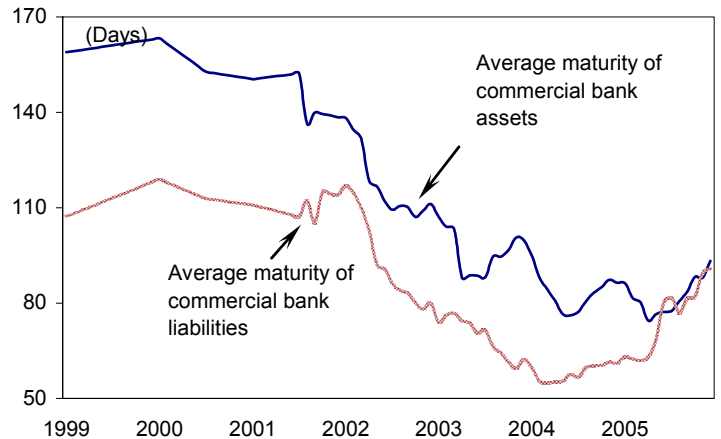

... capitalization ratios remain comfortable...

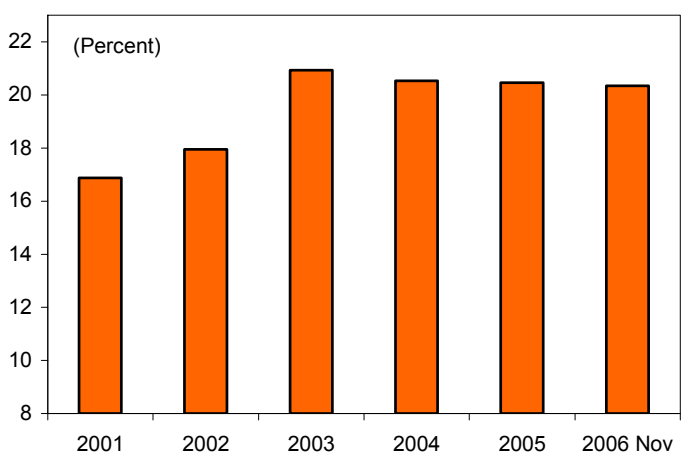

... at the same time, as the confidence in the guarani increases, dollarization is declining..

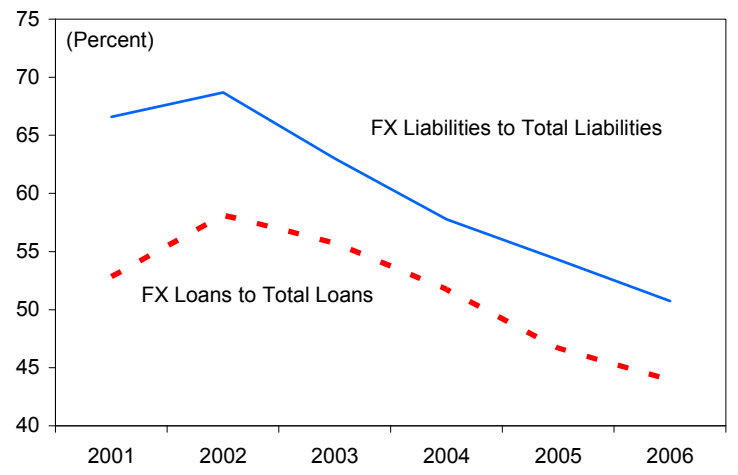

As the quality of banks' portfolios continue to improve, profitability increases....

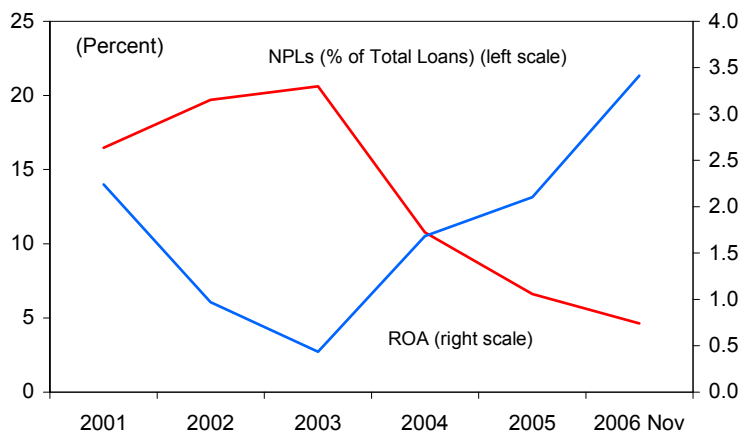

... and even the public BNF is recovering steadily

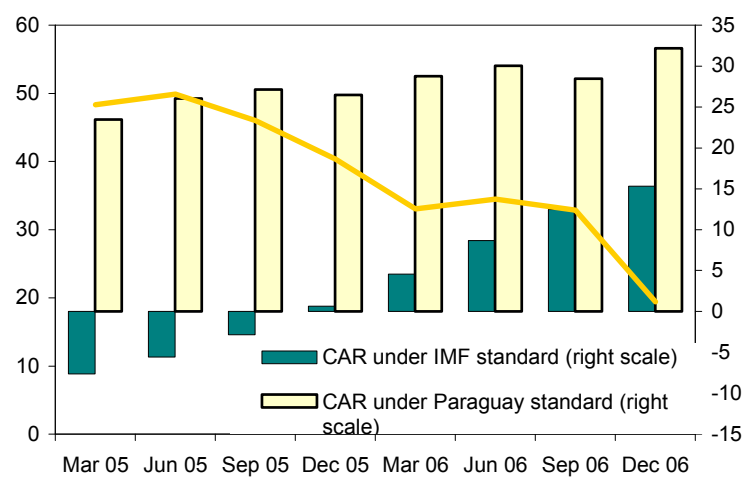

Sources: Paraguayan Authorities and Fund staff estimates. 
Bank of Paraguay. ${ }^{6}$ However, the abundance of foreign exchange complicated monetary management and generated a currency expansion of over 15 percent. These problems intensified in early 2007.

17. Structural Reform 2006. The authorities observed all structural performance criteria and most of the structural benchmarks for the second and third program reviews.

- $\quad \boldsymbol{B N F}$. The audited balance sheet showed a capital adequacy ratio (CAR) of $81 / 2$ percent in June 2006 (against a 5 percent target) and 181/2 percent in December 2006 (against a 10 percent target), owing to high asset recovery and undistributed profits.

- Investment climate. The authorities submitted a plan to improve the investment climate that aims at removing impediments to establishing private enterprises, strengthening property rights, and enhancing competitiveness.

- $\quad$ Tax code. The authorities prepared a tax procedure code that aims at strengthening procedures and penalties related to tax collections and providing better legal and regulatory capacity to the revenue collecting agencies. The draft code was already discussed with private sector experts.

- $\quad$ Public enterprises. Resultoriented management contracts were signed with ANDE, COPACO, ESSAP, INC and PETROPAR to improve the provision of public services, the management of the companies and their financial position.

\begin{tabular}{|c|c|c|}
\hline \multicolumn{3}{|c|}{ Paraguay: Structural Conditionality for $2006 / 07$} \\
\hline Measure & $\begin{array}{l}\text { Conditionality } \\
\text { (Date) }\end{array}$ & Status \\
\hline \multicolumn{3}{|c|}{ Measures Observed } \\
\hline $\begin{array}{l}\text { 1. Audit BNF balance sheet } \\
\text { showing an effective CAR of } \\
5 \% \text { by end-June } 2006 \text {. }\end{array}$ & $\begin{array}{l}\text { Benchmark } \\
\text { (Sep 2006) }\end{array}$ & $\begin{array}{l}\text { Done. Audit conducted in } \\
\text { September } 2006 \text {. It shows a } \\
\text { CAR of } 8 \frac{1}{2} \% \text { by June } 2006 \text {. }\end{array}$ \\
\hline $\begin{array}{l}\text { 2. Plan to improve business } \\
\text { climate. }\end{array}$ & $\begin{array}{l}\text { Benchmark } \\
\text { (Sep 2006) }\end{array}$ & $\begin{array}{l}\text { Done. The authorities } \\
\text { submitted the plan in } \\
\text { September } 2006 \text {. }\end{array}$ \\
\hline 3. Preparation of a tax code. & $\begin{array}{c}\text { PC } \\
\text { (Dec 2006) }\end{array}$ & $\begin{array}{l}\text { Done. A tax code was } \\
\text { approved by the economic } \\
\text { cabinet in December } 2006 .\end{array}$ \\
\hline $\begin{array}{l}\text { 4. Result-oriented management } \\
\text { contracts for ANDE, COPACO, } \\
\text { ESSAP, INC \& PETROPAR. }\end{array}$ & $\begin{array}{l}\text { Benchmark } \\
\text { (Dec 2006) }\end{array}$ & $\begin{array}{l}\text { Done. Contracts with } \\
\text { public enterprises were } \\
\text { signed in December } 2006 .\end{array}$ \\
\hline $\begin{array}{l}\text { 5. Create conditional cash } \\
\text { transfer for } 7,000 \text { families in } \\
\text { extreme poverty. }\end{array}$ & $\begin{array}{l}\text { Benchmark } \\
\text { (Dec 2006) }\end{array}$ & $\begin{array}{l}\text { Done. Over } 8,800 \text { families } \\
\text { participated in the program } \\
\text { by December } 2006 \text {. }\end{array}$ \\
\hline $\begin{array}{l}\text { 6. Audit BNF balance sheet } \\
\text { showing an effective CAR of } \\
10 \% \text { by end-December } 2006 \text {. }\end{array}$ & $\begin{array}{c}\text { PC } \\
\text { (Mar 2007) }\end{array}$ & $\begin{array}{l}\text { Done. Audit conducted in } \\
\text { March } 2007 \text {. It shows a } \\
\text { CAR of } 18 \frac{1}{2} \% \text { by Dec } 2006 \text {. }\end{array}$ \\
\hline \multicolumn{3}{|c|}{ Measures Not Observed } \\
\hline $\begin{array}{l}\text { 7. Implement measures on } \\
\text { banking strategy \& legislation. }\end{array}$ & $\begin{array}{l}\text { Benchmark } \\
\text { (Sep 2006) }\end{array}$ & $\begin{array}{l}\text { Not Done. Political issues } \\
\text { and change in BCP leadership } \\
\text { complicated implementation. } \\
\text { New benchmarks proposed. }\end{array}$ \\
\hline $\begin{array}{l}\text { 8. Strategy to strengthen the } \\
\text { financial position of the } \\
\text { Central Bank. }\end{array}$ & $\begin{array}{l}\text { Benchmark } \\
\text { (Dec 2006) }\end{array}$ & $\begin{array}{l}\text { Not Done. MinFin and BCP } \\
\text { suggest to finalize strategy } \\
\text { by June } 2007 .\end{array}$ \\
\hline $\begin{array}{l}\text { 9. Send bill to Congress with the } \\
\text { legal and budgetary effects of } \\
\text { BCP financial strengthening }\end{array}$ & $\begin{array}{l}\text { Benchmark } \\
\text { (Apr 2007) }\end{array}$ & $\begin{array}{l}\text { Not Done. As strategy has } \\
\text { not been finalized yet. }\end{array}$ \\
\hline
\end{tabular}

- $\quad$ Conditional cash transfers. This program, which conditions household transfers to the children's attendance to school and visits to health centers, covered over 8,800

\footnotetext{
${ }^{6}$ The Central Bank's balance sheet has deteriorated since the mid-1990s, when it had to confront a series of problems in the financial system, including by intervening banks. Since then, the Central Bank records losses, which have been exacerbated by the need to conduct large sterilization operations.
} 
poor families, against a target of 7,000, and enhanced the provision of education and health services to families living under extreme poverty. ${ }^{7}$

- $\quad$ Banks. The strategy for banking reform experienced a serious setback. The introduction of a key Central Bank regulation (resolution 8/03) was postponed by more than 1 $1 \frac{1}{2}$ years (to August 2008) after strong opposition from banks and their borrowers, deteriorating significantly the climate for reform in this area. ${ }^{8}$ Given these difficulties, the authorities could not implement program conditionality related to additional prudential regulations nor send to Congress amendments to the banking law. The authorities propose to reinvigorate the reform efforts in this area with a new approach (see the section on financial sector policies for 2007).

- $\quad \boldsymbol{B C P}$. While significant progress has been made in finding a solution to the financial situation of the Central Bank, the strategy to strengthen its balance sheet has not been finalized. Consequently, the authorities did not send the legal and budgetary implication of such strategy to Congress. The authorities are requesting to reset these benchmarks.

- $\quad$ Fuel Issues. With fluctuations in international oil prices, domestic price adjustments, and the appreciation of the guarani, diesel subsidies have been reduced significantly in line with policy intentions to liberalize the diesel price. ${ }^{9}$

18. External Issues 2006. The authorities reiterated their commitment to eliminate PETROPAR arrears by September 2007; these amounted to almost US\$30 million at end2006. Some progress was made in dealing with the debts in dispute..$^{10}$

\footnotetext{
${ }^{7}$ A preliminary evaluation of the program suggests that it was effective in alleviating extreme poverty and in raising economic activity in the areas where these families live.

${ }^{8}$ Resolution 8/03 would have strengthened bank's loan classification and provisioning requirements. However, bank borrowers feared that the resolution would deteriorate their credit rating and bankers opposed to it because they worry about unfair competition from financial cooperatives, which are not subject to prudential regulations. The Central Bank is encouraging banks to adhere to resolution $8 / 03$ on a voluntary basis. This resolution was approved by the Central Bank board in November 2003 and was expected to enter into effect in January 2007. There was no conditionality attached to resolution $8 / 03$ under the SBA.

${ }^{9}$ The law to provide subsidies to transport companies (in compensation for diesel price adjustments) was submitted to Congress in May 2006, but has not been approved yet.

${ }^{10}$ There were three kind of claims in dispute at end-2006 amounting to some US\$170 million or about 13/4 percent of GDP: (i) Belgium's Ex-Herstal (US\$7 million), negotiations continue between both parties; (ii) French and Swiss import verification companies (US\$75 million), the authorities continue studying possible solutions; in the meantime, the French company (BIVAC) submitted a claim against Paraguay at the World Bank Settlement Body (ICSID) in April 2007; and (iii) European and American banks, following a Swiss court ruling against Paraguay (US\$85 million), the authorities have decided to elevate the case to the International Court of Justice in The Hague.
} 
Figure 5. Paraguay: Balance of Payments Developments

A benign external environment has produced a favorable balance of payments in the last few years. The external position was particularly good in 2006 driven by high foreign direct investment.

The BOP improved, driven by capital inflows...

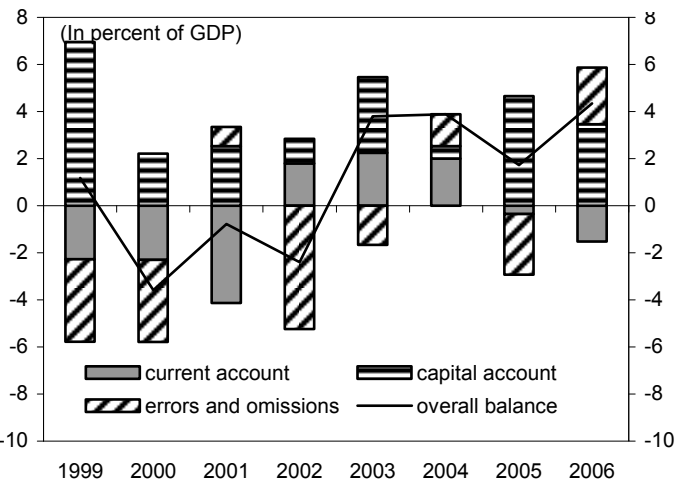

...and the emergence of meat as a major export.

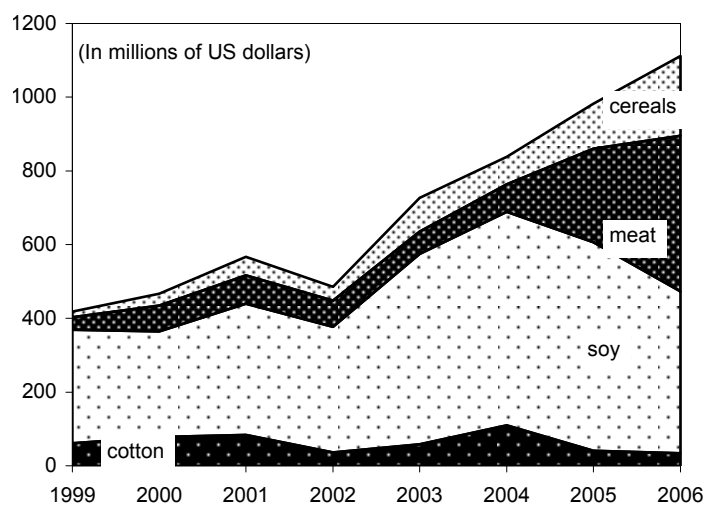

.... with NIR increases driven by large inflows from binationals. ...including FDI...

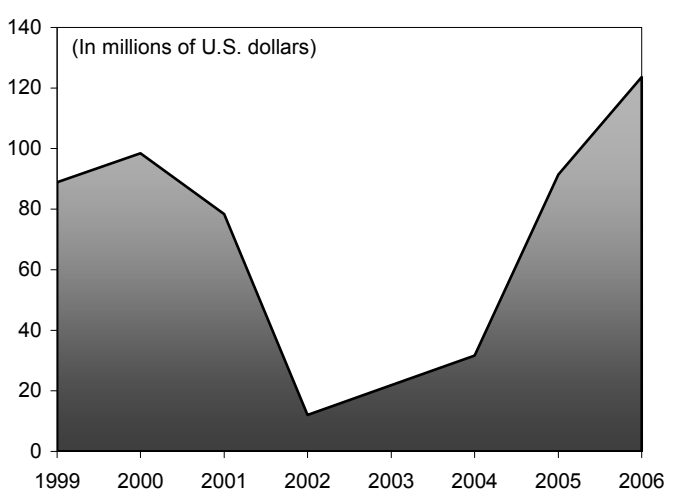

Re-exports drove imports to a record high...

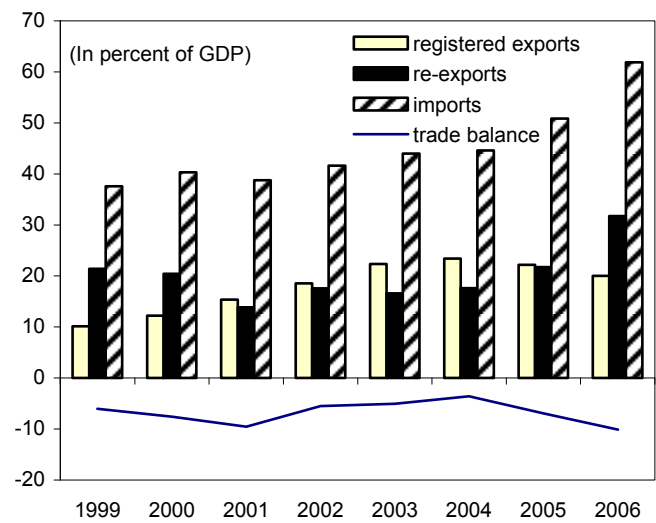

External debt stabilized even as the private sector borrowed more.

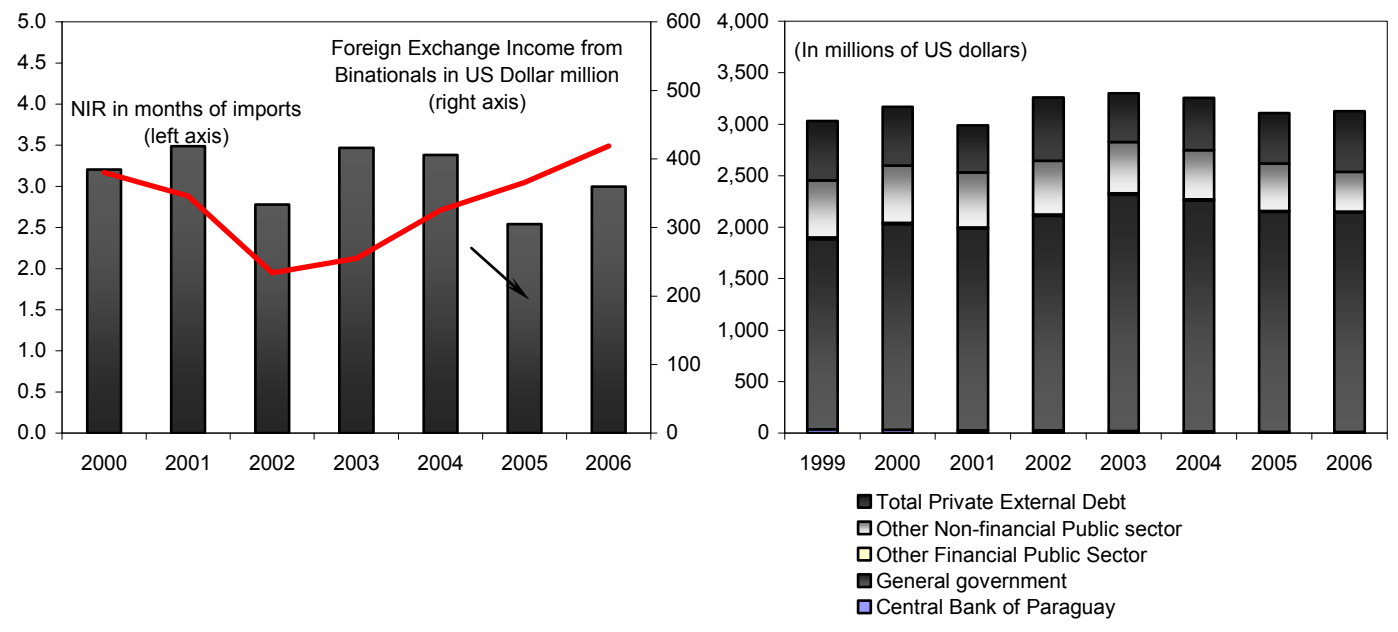

Sources: Paraguayan Authorities and Fund staff estimates. 


\section{Policy Discussions ANd the 2007 Program}

19. Focus. The Article IV consultation discussions focused on the main economic problems facing the authorities: low growth and widespread poverty. To address these problems, five reform areas were identified: (i) strengthening macroeconomic management; (ii) reinforcing fiscal institutions;

(iii) tackling financial weaknesses;

(iv) developing a pro-growth policy agenda; and (v) designing an effective poverty reduction policy. To help address these issues, the staff prepared selected issues papers in each of these areas. The papers were discussed with the authorities in seminars during the December 2006 mission (in collaboration with the World Bank and

\begin{tabular}{|c|c|c|c|c|}
\hline \multicolumn{5}{|c|}{ Paraguay: Macroeconomic Framework } \\
\hline & Prog. & Est. & $\mathrm{Pr}$ & \\
\hline & \multicolumn{2}{|c|}{2006} & 2007 & 2008 \\
\hline \multicolumn{5}{|c|}{ (Annual percent change) } \\
\hline Real GDP & 3.5 & 4.0 & $4-5$ & $4-5$ \\
\hline Inflation (e.o.p.) & 7.0 & 12.5 & $21 / 2-71 / 2$ & 3.0 \\
\hline \multicolumn{5}{|c|}{ (In percent of GDP) } \\
\hline External current account & -2.2 & -1.5 & -1.3 & -1.7 \\
\hline Overall fiscal balance & 0.0 & 0.2 & 0.0 & 0.0 \\
\hline Consolidated public debt & 38.3 & 34.1 & 30.7 & 28.9 \\
\hline
\end{tabular}
IDB staffs). The policy priorities that emerged from those discussions were used to shape the authorities' macroeconomic policies and structural reform agenda for 2007. These policies and reforms are consistent with the medium-term framework presented in the May 2006 program (Country Report No. 06/302).

\section{A. Strengthening Macroeconomic Management}

20. Macroeconomic Stability. There was broad agreement that continued strengthening of the fiscal and monetary frameworks is needed to entrench macroeconomic stability and create the conditions for faster growth and poverty reduction. The authorities stressed their commitment to maintaining macroeconomic stability, but noted that this task would be more demanding in the forthcoming pre-electoral period. The authorities' program aims at raising real GDP growth to the 4-5 percent range in 2007 and 2008, while reducing core inflation to 5 percent (within a $+/-2 \frac{1}{2}$ percent range) in 2007 and 3 percent in 2008 . Key elements of the program include (Box 1) ( $₫ 6):{ }^{11,12}$

- $\quad$ Fiscal Policy 2007. The authorities are strengthening their ability to conduct countercyclical fiscal policies, while preserving fiscal sustainability, and therefore are targeting broad fiscal balance for 2007. This would imply a tightening of policy

\footnotetext{
${ }^{11}$ The symbol 9 refers to the paragraph number in the authorities' MEFP (Appendix 2).

${ }^{12}$ See Chapter I in the companion Selected Issues Paper for a detailed description of macroeconomic issues and policies in the program.
} 


\section{Box 1. Paraguay: The Focus of Macroeconomic Policies}

\section{Assessing the cyclical position of the economy is essential to avoid policies that exacerbate} economic fluctuations. Different methodologies can be used to estimate the output gap. A key policy objective is to conduct counter-cyclical policies to minimize the variability of output. Other important considerations are debt sustainability for fiscal policy and price stability for monetary policy.

The economy appears to be above its potential after coming out of a long period of stagnation and instability. Since the high-growth episode in the 1970s with average growth of 7.7 percent, Paraguay has experienced very poor performance culminating in a decade of stagnation with recurrent crises in the late 1990s. However, since 2003, the average rate of growth has recovered to 3.5 percent. In addition, the recent growth period seems to be associated with less volatility. Various methodologies to estimate the output gap (Cobb-Douglas production function, Okun's Law, or statistical filters such as HodrickPrescott filter or the "Ideal" Pass filter) suggest that the economy is currently above its long-term trend (see Chapter I in the companion Selected Issues Paper).

Although mildly countercyclical, fiscal policy needs to be strengthened to better "lean against the wind." Fiscal policy was assessed using the fiscal impulse methodology. Fiscal policy was broadly neutral in the early 1990s and supportive of growth during the protracted crises of the late 1990s. During 2000-04, fiscal policy was on average countercyclical and contributed significantly to the reduction of the debt ratio. However, in 2005-06, despite the high point in the business cycle, fiscal policy was not as strong as a proper countercyclical policy would have dictated (although this reflects in part increased public investment).

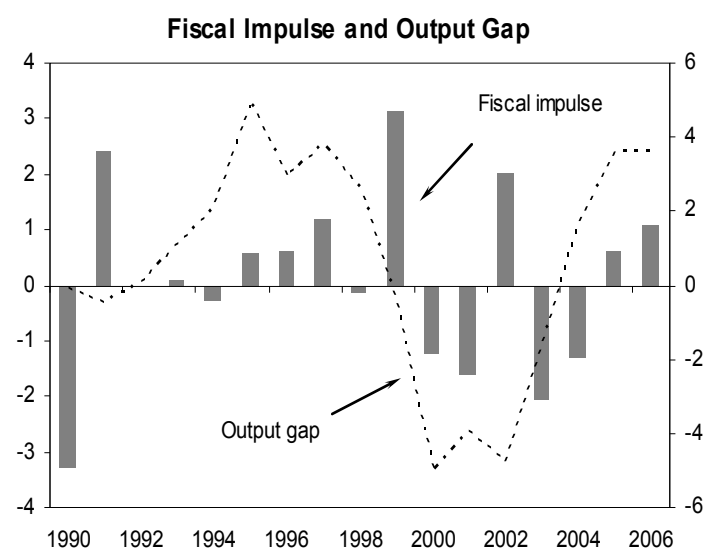

Monetary policy was geared more toward stabilizing the exchange rate but recently more emphasis has been given to controlling inflation. The previous focus on the exchange rate as a policy objective reflects the high degree of dollarization of both assets and liabilities and the high exchange rate pass-through to inflation. Estimation of a Taylor rule augmented by open economy variables shows that the policy interest rate has responded to changes in the exchange rate or to the level of net international reserves, with lower reserves leading the country to be more defensive in terms of interest rate. This behavior is similar to some extent to that in other highly dollarized economies, and contrasts with lowly dollarized economies where the monetary rule responds to the

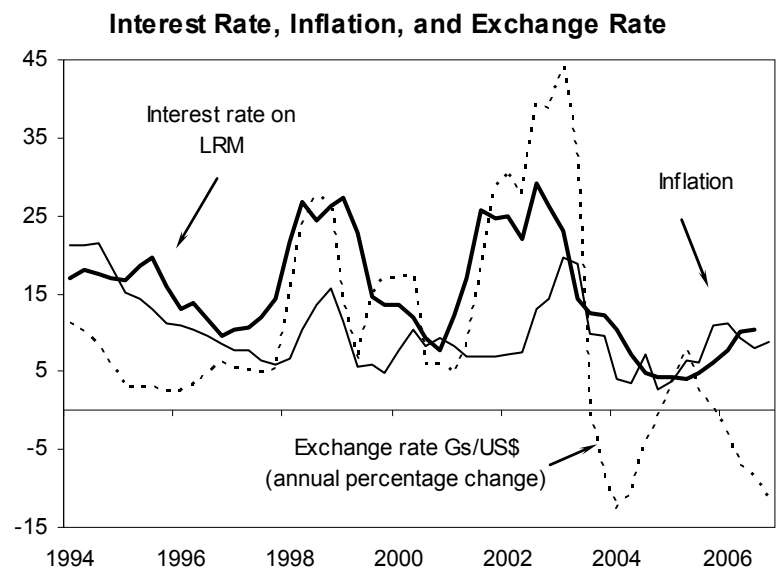
traditional determinants of inflation and output gap. In 2005-06, however, a change too recent to be captured in regression analysis, interest rates were raised to respond to inflationary pressures. Over the medium-run, Paraguay would gain from pursuing consistently a monetary policy more focused on inflation. 
relative to the approved budget ( $(7) \cdot{ }^{13}$ Continued application of the fiscal adjustment law, and restraint in current spending through a financial plan approved in March 2007 will make room for increasing capital spending while maintaining overall balance at the Treasury level. The staff encouraged the authorities to save one-half of any revenue over-performance to strengthen their fiscal position even further while using the reminder of the over-performance to step up social spending and poverty reduction programs. However, the authorities believed that it will be difficult to increase public savings further in the current political environment. The rest of the public sector will maintain a small surplus

\begin{tabular}{|c|c|c|c|c|c|}
\hline \multicolumn{6}{|c|}{$\begin{array}{l}\text { Paraguay: Fiscal Program 1/ } \\
\text { (In percent of GDP) }\end{array}$} \\
\hline & \multirow[b]{2}{*}{ Prog. } & \multicolumn{4}{|c|}{ Approved Effective } \\
\hline & & Est. & & & Proj. \\
\hline & \multicolumn{2}{|c|}{2006} & \multicolumn{2}{|c|}{2007} & \\
\hline Total Revenues & 17.9 & 18.4 & 19.1 & 18.2 & 18.2 \\
\hline o/w Tax & 11.3 & 12.1 & 11.5 & 12.1 & 12.1 \\
\hline Total Expenditures & 17.9 & 17.9 & 19.9 & 19.9 & 18.2 \\
\hline o/w Wages & 7.4 & 7.4 & 7.8 & 7.8 & 7.7 \\
\hline o/w Capital & 4.3 & 4.2 & 5.4 & 5.4 & 4.4 \\
\hline Discrepancy & -- & -0.4 & -- & -- & -- \\
\hline Overall Balance & 0.0 & 0.1 & -0.8 & -1.7 & 0.0 \\
\hline
\end{tabular}
to compensate for the projected central bank losses and permit achieving a balanced

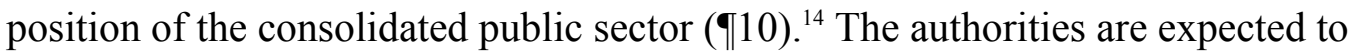
make further progress in 2007 towards their objective of a consolidated public debt of no more than 30 percent of GDP (Box 2).

- Monetary Policy 2007. The objective for 2007 is to reduce core inflation to 5 percent through a monetary program that limits the growth of currency issue to 12 percent, which is consistent with a modest recovery in real money demand ( $₫ 11)$. To this end, the Central Bank will maintain a tight credit policy stance by reducing its net domestic assets by some 20 percent of currency through the active placement of "Letras de Regulacion Monetaria", while at the same time tolerating a

\begin{tabular}{|c|c|c|c|}
\hline \multicolumn{4}{|c|}{$\begin{array}{l}\text { Paraguay: Monetary Program 1/ } \\
\text { (In percent of currency the previous period) }\end{array}$} \\
\hline & Prog. & Est. & Proj. \\
\hline & \multicolumn{2}{|c|}{2006} & 2007 \\
\hline Currency Issue & 8.5 & 15.3 & 12.0 \\
\hline Net international reserves & 4.3 & 87.1 & 32.9 \\
\hline Net domestic assets & 4.2 & -71.8 & -20.9 \\
\hline Credit to public sector & 6.5 & -23.3 & -2.7 \\
\hline Credit to banks & -18.1 & -15.7 & -38.5 \\
\hline Other items & 15.8 & -32.8 & 20.3 \\
\hline
\end{tabular}
large build-up in international reserves of 33 percent of currency. This credit-reserve

\footnotetext{
${ }^{13}$ The 2007 budget approved by Congress in December 2006 envisages a deficit of $3 / 4$ percent of GDP, which effectively implies a deficit of $13 / 4$ percent of GDP, once adjustments are made for more realistic revenue collections. As in previous years, however, the authorities have adopted a financial plan to contain current expenditures and avoid unnecessary delays in the execution of the investment program.

${ }^{14}$ In line with previous practice, the 2007 fiscal targets can be relaxed in the context of program reviews if additional capital spending on high quality projects is identified, provided it is accompanied with adequate financing and does not jeopardize macroeconomic stability. The staff does not expect this additional public investment to exceed $1 / 2$ percent of GDP.
} 


\section{Box 2. Paraguay: Fiscal Challenges}

An ambitious fiscal reform agenda needs to be put in place to support growth and poverty reduction. The medium-term fiscal agenda should consolidate recent improvements in public finances and deepen the reform in a number of areas, including by: (i) locking in revenue gains; (ii) reorienting expenditure and reducing rigidities; and (iii) strengthening budgetary procedures and expenditure financial management (see Chapter II on fiscal reform in the companion Selected Issues Paper).

Revenues. The tax revenue-to-GDP ratio has been relatively low compared to other countries in the region, although it has improved in recent years. A tax reform aimed at creating a more effective and revenue generating tax system was approved in 2004. The government's tax strategy is to increase the tax-to-GDP ratio gradually by broadening the tax base (applying moderate rates), and enhancing administrative tax efficiency. The authorities have introduced tax and customs administration reforms focused on enforcement and compliance, with technical support from the Fund and other international institutions. These

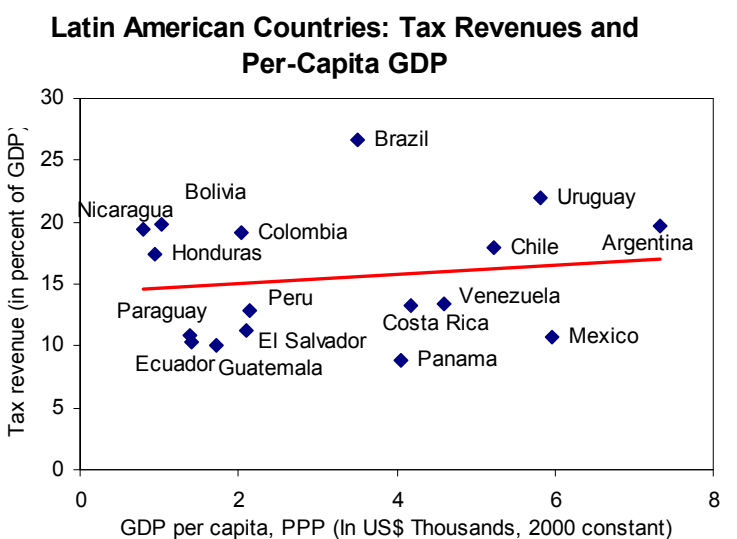
achievements need to be supplemented by additional efforts to strengthen revenue administration and improve revenue performance further. The legal ambiguity of the civil service law regarding the career system of civil servants is delaying needed reforms in human resource for Customs and the Tax Office.

Expenditures. Key objectives of an expenditure policy will be to reduce further budget rigidity and enhance spending efficiency. To accomplish these objectives, it would be important to link wage increases to productivity improvements, adopt attrition policies, reduce government contribution to pensions, restrict revenue earmarking, enhance efficiency in the use of public resources (i.e., by strengthening public investment criteria), and set hard budget constraints to the judicial and legislative branches. The wage bill is relatively high, and claims almost 80 percent of tax revenue and more than 40 percent of general government spending. The pension system coverage is low by regional standards for both active workers and the elderly, but the budgetary transfers to the system are relatively large. There is no independent capacity to evaluate investment projects and to assist in its prioritization, causing the capital budget to be spread too thin.

Budget. The Public Financial Management system has some weaknesses. The budget process needs to enhance transparency, discipline, realism, and accountability, as well as its legal framework. The lack of realism in the budget translates in systematic overbudgeting at the budget formulation stage which leads to a high degree of uncertainty about the stance of fiscal policy. It is important to establish a mediumterm framework to improve budget preparation, prioritization, and sustainability.

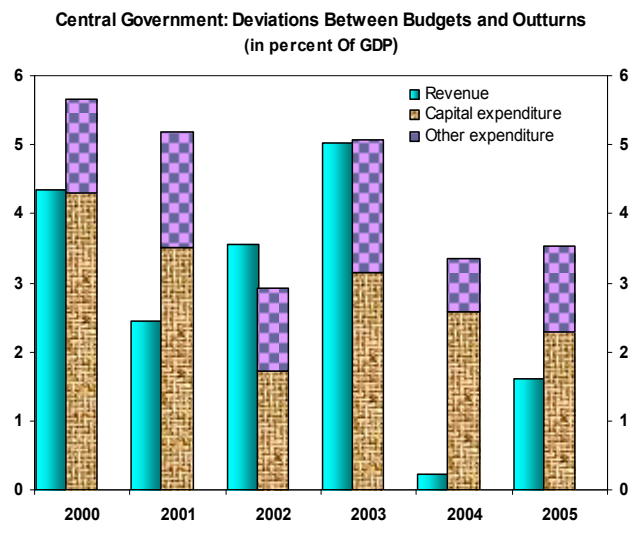


mix was designed to accommodate a large influx of foreign exchange observed in the first four months of 2007. The authorities feared that a significant part of these amounts were temporary private capital flows and decided to intervene to prevent an abrupt appreciation of the currency. They also reduced significantly interest rates on the benchmark LRMs by over 600 basis points to about $4 \frac{1}{2}$ percent to discourage further inflows. While real interest rates are still positive in the short-run, nominal interest rates may need to be raised in the next months to maintain domestic credit within program limits and achieve the core inflation objective. Foreign exchange inflows fell significantly by end-April 2007 (\$12). Over the medium term the authorities intend to reduce inflation to industrial country levels.

- $\quad$ Exchange Rate Policy 2007. The authorities will maintain a flexible exchange rate with intervention aimed at achieving their net international reserve target as well as smoothing out large and/or seasonal transactions ( $\ 12)$. The staff considers that Paraguay's floating exchange rate regime is appropriate in light of the need to absorb shocks. The recent strengthening of the guaraní comes after a sharp real depreciation during the 2002 crisis, and there is currently no conclusive evidence of large exchange rate misalignments; in real effective terms, the guarani is only slightly appreciated relative to the average of the last 10 years. However, econometric studies indicate that on the basis of past behavior, the guarani may be somewhat overvalued (between 6 to 8 percent ) (Box 3). However,

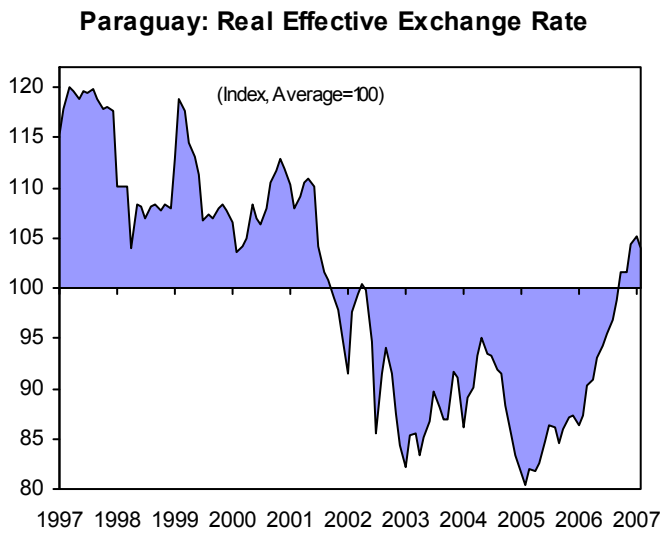
the strengthening of the current account and the higher foreign direct investment may signal some shift in the equilibrium real exchange rate. The staff believes that it is too early to tell if the inflows of the last few months were due to temporary capital inflows (a regional phenomenon) or more permanent improvements in the current account, and suggested to the authorities to monitor closely the situation and be prepared to allow the guarani to appreciate if there is conclusive evidence that the fundamentals have strengthened.

- $\quad$ External Sector 2007. The current account deficit as a percent of GDP is projected to fall slightly in 2007 mostly due to improvements in the trade balance as Paraguay will continue to benefit from strong agricultural exports. The capital account is projected to show another large surplus, mainly owing to foreign direct investment.

\begin{tabular}{|c|c|c|c|}
\hline \multicolumn{4}{|c|}{$\begin{array}{l}\text { Paraguay: Balance of Payments } \\
\text { (In percent of GDP) }\end{array}$} \\
\hline & $\frac{\text { Prog. }}{200}$ & $\begin{array}{ll}\text { Est. } \\
6\end{array}$ & $\begin{array}{l}\text { Proj. } \\
2007\end{array}$ \\
\hline $\begin{array}{l}\text { Current Account } \\
\text { o/w Exports } \\
\text { o/w Imports }\end{array}$ & $\begin{array}{r}-2.2 \\
39.9 \\
-47.2\end{array}$ & $\begin{array}{r}-1.5 \\
51.7 \\
-61.8\end{array}$ & $\begin{array}{r}-1.3 \\
48.3 \\
-56.3\end{array}$ \\
\hline $\begin{array}{l}\text { Capital Account } \\
\text { Public sector (net) 1/ } \\
\text { Private sector (net) 2/ }\end{array}$ & $\begin{array}{l}2.8 \\
0.1 \\
2.6\end{array}$ & $\begin{array}{l}5.9 \\
0.1 \\
5.8\end{array}$ & $\begin{array}{l}3.5 \\
0.2 \\
3.3\end{array}$ \\
\hline Overall Balance & 0.6 & 4.4 & 2.2 \\
\hline
\end{tabular}




\section{Box 3. Paraguay: Is the Exchange Rate Misaligned?}

An update of a standard model to assess the REER against its fundamentals shows similar econometric results. ${ }^{1}$ The model includes traditional determinants of equilibrium exchange rate (EER). Better terms of trade and higher net foreign assets lead to appreciations of the EER through wealth effects. Trade openness increases competition in tradable goods, thus depreciating the EER, while an improvement in the fiscal balance has the same impact through a reduction of the demand for nontradable goods. Productivity increase in the tradable sector raises the relative price of nontradable goods, thus raising the EER (the Balassa-Samuelson effect). Finally, an increase in capital inflows (reflected in a deterioration in the current account) may cause an appreciation of the EER as the demand for nontradables increases. Minor changes were made to the model, such as broadening the terms of trade beyond soybeans and cotton, to include cereals and beef, which have became important export items. The model

\begin{tabular}{|c|c|c|c|c|}
\hline \multicolumn{5}{|c|}{ Estimation of Equilibrium REER Equation 1/ } \\
\hline & \multicolumn{2}{|c|}{ Benelli (2004) } & \multicolumn{2}{|c|}{ Update (2007) } \\
\hline & Coeff. & Std.Dev. & Coeff. & Std.Dev. \\
\hline Current Account 2/ & -1.64 & 0.50 & -2.18 & 0.46 \\
\hline Fiscal Balance 2/ & -1.84 & 0.10 & -1.78 & 0.92 \\
\hline Terms of Trade & 0.31 & 0.14 & 0.15 & 0.09 \\
\hline Net Foreign Assets & -0.09 & 0.10 & 1.01 & 0.45 \\
\hline Openess $2 /$ & -0.32 & 0.10 & -0.23 & 0.07 \\
\hline Relative Per Capita GDP & 1.12 & 0.48 & 0.95 & 0.13 \\
\hline REER Argentina & 0.10 & 0.06 & $\ldots$ & $\ldots$ \\
\hline REER Brazil & 0.00 & 0.13 & $\ldots$ & $\ldots$ \\
\hline Adjusted $R^{2}$ & & 0.93 & & 0.95 \\
\hline No. of Observations (N) & & 24 & & 27 \\
\hline Period & & $980-2003$ & & $1980-2006$ \\
\hline \multicolumn{5}{|c|}{$\begin{array}{l}\text { 1/ OLS estimates. Given some non-stationary variables, standard } \\
\text { deviations are only indicative but OLS estimates are consistent. } \\
\text { 2/ As a percent of GDP. }\end{array}$} \\
\hline
\end{tabular}
has been re-estimated to include the latest data 1980-2006 (see table). Unlike Benelli, the REER of Argentina and Brazil have been omitted as these likely reflect effects already captured by other variables. The explanatory variables all have the expected sign and the coefficients are broadly similar to those of the earlier Benelli study.

However, the results suggest that the undervaluation of the REER following the 2002 crisis has been corrected, and that the REER may currently be stronger than suggested by its fundamentals. The figure below presents the regression residuals (i.e., short-term misalignment) as well as the deviations in the REER implied by the regression coefficient when the fundamentals are evaluated at their long term trend values (computed by applying the Hodrick-Prescott filter to each series) (i.e., long-term misalignment). The results are broadly similar. For end-2006 the model points to a possible small overvaluation of 6 to 8 percent. As the figure suggests, part of the 12 percent REER appreciation in 2006 is not reflected in its fundamentals,

Real Exchange Rate Misalignment (Estimated from Equilibrium Relationship)

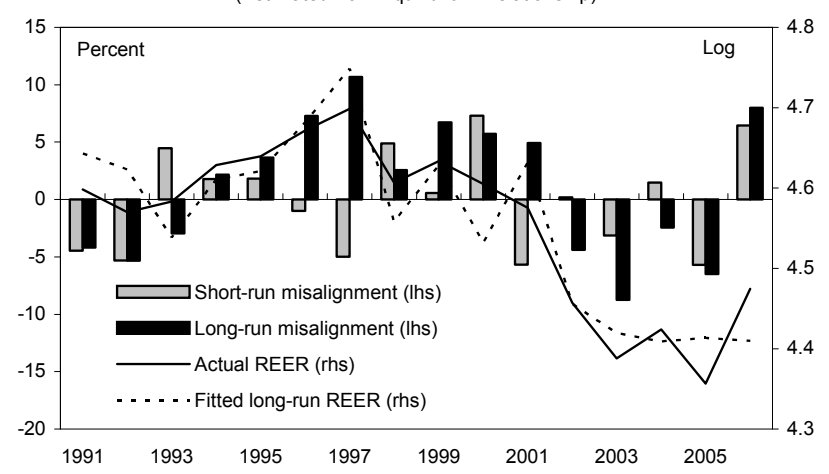
which remained broadly unchanged. In addition, in the first quarter of 2007, the REER appreciated further. However, while the model does not explain intra-year variations, part of the recent appreciation could be explained by structural changes that are not yet adequately reflected in the data series (such as increased productivity in agroindustrial sectors, improved terms of trade, higher NFA, and better GDP growth prospects).

1 "Equilibrium Exchange Rate in Paraguay" by Roberto Benelli, Selected Issues Paper, IMF, 2004. 
- Medium-Term Scenario. The scenario presented in the staff report for the SBA request (Country Report No. 06/302) remains valid in view of the authorities' commitment to continue pursuing prudent macroeconomic policies and implementing structural reforms to sustain growth, supported by favorable external conditions. Prudent macroeconomic policies should aim at increasing public resources to reduce poverty and improve infrastructure, and broad-based economic reforms should help entrench stability, and sustain medium-term growth by encouraging private investment, and augmenting productivity. Under this scenario, real GDP growth would rise to 5 percent by 2010, while price and financial stability would be maintained. Continued fiscal consolidation would permit a decline of the public debtto-GDP ratio to just over 20 percent by 2012 (see Appendix 5 for a debt sustainability analysis).

\section{B. Reinforcing Fiscal Institutions}

21. Medium-Term Institutional Reform. In view of Paraguay's institutional weaknesses, there was agreement on the need for a medium-term reform of fiscal institutions to promote fiscal sustainability, improve the flexibility of fiscal policy, and support long-term growth potential by better targeting social spending and infrastructure investment. Work in most of these areas has already begun, and will continue over the next years. The reforms include: (i) enhancing the institutional framework of tax and customs administrations to consolidate recent revenue gains and support additional revenue mobilization; (ii) strengthening public financial management, in particular the budget framework, to improve expenditure efficiency and control; (iii) reducing budget rigidities to permit a more flexible expenditure allocation process; (iv) rationalizing the civil service to improve service delivery; and (v) reforming the pensions regime to increase coverage and secure financial sustainability (Box 2). ${ }^{15}$

22. 2007 Institutional Fiscal Policies. In view of the discussions and the challenges ahead, the authorities are focusing their efforts in 2007 on institutional fiscal policies in four areas: ${ }^{16}$

- $\quad$ Tax code. The authorities are strengthening the institutional framework for tax collection. In particular, they have recently drafted a tax procedures code, and they are preparing the implementing regulations (\$14). ${ }^{17}$ This involves the drafting of legal

\footnotetext{
${ }^{15}$ See Chapter II in the companion Selected Issues Paper for a detailed description of the structural fiscal issues and policies in the program.

${ }^{16}$ See Appendix 6 for a detailed description of the technical assistance program, which was designed to support the main objectives of the authorities' program.
} 
provisions to develop new streamlined compliance control procedures. The staff encouraged the authorities to reach a consensus within civil society before submitting a draft tax code to Congress, and then work with the relevant commission to explain the policies and ensure its approval.

- Pension reform. In view of the low coverage, lack of regulation, fragmented structure of the pension system, and the need to minimize contingent liabilities, the authorities will develop a pension reform plan aimed at addressing these concerns and ensuring the long-term solvency of the pension system (\$15). The staff recommended that the plan be followed by a parametric reform of the whole system.

- $\quad$ Expenditure control. To strengthen the ability of the Ministry of Finance to limit expenditures, the authorities will establish an expenditure control system at the commitment level for the Executive Branch ( $\ 15)$. This reform is key to improving the quality of spending and eliminating the practice of reaching fiscal objectives by underexecuting capital expenditures, while identifying remaining outstanding obligations. The staff stressed the need to implement a Treasury single account, to enhance expenditure

\begin{tabular}{|lc|}
\hline \multicolumn{2}{|c|}{ Paraguay: Fiscal Structural Benchmarks for $\mathbf{2 0 0 7}$} \\
\hline \multicolumn{1}{|c|}{ Measure } & Date \\
\hline $\begin{array}{l}\text { 1. Draft implementing regulations for the } \\
\text { tax procedures code }\end{array}$ & Sep 2007 \\
$\begin{array}{l}\text { 2. Develop an action plan for a } \\
\text { comprehensive pension reform }\end{array}$ & Sep 2007 \\
$\begin{array}{l}\text { 3. Establish an expenditure control system } \\
\text { at the commitment level }\end{array}$ & $\operatorname{Dec} 2007$ \\
$\begin{array}{l}\text { 4. Create a public sector investment system } \\
\text { Sources: Paraguayan authorities and Fund staff. }\end{array}$ & $\operatorname{Dec} 2007$ \\
\hline
\end{tabular}
control; the authorities are in the process of reducing the number of public accounts with a view to achieve the single account.

- $\quad$ Public investment. To achieve a better integration between the long-term objectives of specific sectors and the investment projects being selected, the Ministry of Finance will design a public sector investment system that ensures that programs reflect government priorities, improves prioritization and efficiency, maximizes investment return, and removes budget rigidities ( $(\mathbb{1 5})$.

\section{Tackling Financial System Weaknesses}

23. Strengthening the Financial System. The authorities agreed that the low intermediation capacity of the financial system hinders economic growth, and are considering a wide range of reforms that are in line with the recommendations made by the 2005 FSAP.

\footnotetext{
${ }^{17}$ The recently drafted tax procedures code consolidates tax legislation and aims at increasing tax revenue due under existing tax laws. The tax administration has to enforce compliance while at the same time assist taxpayers to comply with tax laws' requirements. In this vein, the draft tax procedures code intends to establish a proper balance between the powers of the tax administration to administer the tax laws and the protection of taxpayers' rights.
} 
These include: (i) strengthening the financial position of the Central Bank; (ii) improving the framework for monetary operations; (iii) upgrading banking regulation and supervision; (iv) restructuring public banks (especially BNF); (v) strengthening the regulation and supervision of financial cooperatives; (vi) developing domestic capital markets; and (vii) enhancing the payment system. ${ }^{18}$

24. 2007 Financial Sector Policies. The authorities stressed their commitment to address the shortcomings of the financial system, and regretted recent setbacks in the implementation of the financial sector reform agenda. They noted that implementation of some reforms will take longer than anticipated because of the complex political landscape in 2007, and therefore their efforts will concentrate on the following areas:

- Monetary authority. The authorities are determined to address the Central Bank's negative income position, and are designing a strategy to strengthen the financial position of the Central Bank. They intend to submit to Congress a bill with the legal and budgetary implications of the strategy by September 2007 ( $\mid 18)$. This financial exercise will allow the Central Bank to focus more on monetary policy issues rather than the implication of its actions on the balance sheet.

- $\quad$ National Development Bank. The authorities intend to continue their efforts to strengthen the national development bank (BNF) and minimize its potentially systemic risk. To consolidate further BNF's financial position, and limit future political interference with the bank's lending policies, the authorities are developing a medium-term business strategy to refocus its operations, reduce operating costs, increase asset recovery, improve credit and risk management practices, and enhance internal controls ( $\$ 17)$. The staff encouraged the authorities to include in the plan a clear timetable and the need for some downsizing.

\begin{tabular}{|c|c|}
\hline \multicolumn{2}{|c|}{ Paraguay: Financial Structural Benchmarks for 2007} \\
\hline Measure & Date \\
\hline $\begin{array}{l}\text { 1. Announce strategy to strengthen financial } \\
\text { position of } B C P\end{array}$ & Jun 2007 \\
\hline $\begin{array}{l}\text { 2. Develop plan for BNF to reduce costs, recover } \\
\text { assets, and improve risk management }\end{array}$ & Jun 2007 \\
\hline $\begin{array}{l}\text { 3. Design plan to strengthen financial reform and } \\
\text { increase compliance with Basel Principles }\end{array}$ & Jun 2007 \\
\hline $\begin{array}{l}\text { 4. Develop legal and regulatory framework to } \\
\text { revamp the payment system }\end{array}$ & Sep 2007 \\
\hline $\begin{array}{l}\text { 5. Send bill to Congress with legal and budgetary } \\
\text { implications of plan to strengthen BCP }\end{array}$ & Sep 2007 \\
\hline $\begin{array}{l}\text { 6. Develop supervisory and regulatory framework } \\
\text { for cooperatives }\end{array}$ & Sep 2007 \\
\hline $\begin{array}{l}\text { 7. Reinstate modified Resolution } 8 / 03 \text { to become } \\
\text { effectiove on January } 1,2008\end{array}$ & Sep 2007 \\
\hline $\begin{array}{l}\text { 8. Design strategy for the development of capital } \\
\text { markets }\end{array}$ & Dec 2007 \\
\hline $\begin{array}{l}\text { 9. Implement prudential regulations in line with } \\
\text { BCP's operational plan }\end{array}$ & Dec 2007 \\
\hline
\end{tabular}

- $\quad$ Payments system. To address weaknesses in the payments system, facilitate the development of capital markets, and mobilize financial resources, the Central Bank is preparing a draft law to revamp the payments system (\16). Furthermore, the

\footnotetext{
${ }^{18}$ See Chapter III in the companion Selected Issues Paper for a detailed description of the financial sector issues and policies in the program. See also Appendix 4 for an assessment and update of the status of the financial system.
} 
authorities will intensify their efforts to put in place a real-time gross settlement system (RTGS) and an automatic clearing house (ACH).

- $\quad$ Capital markets. The authorities agreed that the financial strengthening of the Central Bank will provide opportunities for developing capital markets. They are designing a comprehensive strategy for the development of capital markets, including by promoting the domestic securities market and strengthening the public debt management system (\19).

- Cooperatives. The authorities believe that a strengthening of the regulatory, supervisory and monitoring framework for the largest cooperatives is key to the financial sector reform. The objective is to reduce the difference in the regulatory framework for different kinds of financial institutions and to minimize systemic financial vulnerabilities and distortions (\$16).

- $\quad$ Commercial banks. The Central Bank has developed a new approach to upgrading banking regulation and supervision, addressing remaining weaknesses identified in the FSAP exercise. This approach includes: (i) designing a strengthened strategy to achieve at least 80 percent of the Basel Core Principles for banking supervision over the medium-term (consistent with best practice in the region); (ii) approving a modified resolution 8/03 - which seeks to strengthen bank's loan classification and provisioning requirements - to become effective by January 1, 2008 (see Appendix 4); and (iii) implementing prudential regulations in line with the Central Bank’s operational plan (\$16).

\section{Developing a Pro-Growth Policy Agenda}

25. Raising Productivity. The authorities pointed to progress made in the last few years, and stressed that achievement of permanent gains in potential output growth through raising productivity is part of their medium-term, broad-based agenda aimed at boosting per-capita income growth. ${ }^{19}$

26. 2007 Growth Policies. The authorities noted that their efforts in 2007 will focus on two areas:

- Investment climate. The authorities expressed concern about the low level of private investment in the economy. To address this problem, they will implement the action plan designed in the fall of 2006, which aims at removing disincentives for investment, and enhancing the business and investment climate (\$20). The authorities' plan rests on five main pillars: (i) facilitate enterprise creation;

\footnotetext{
${ }^{19}$ See Chapter IV in the companion Selected Issues Paper for a detailed description of growth issues and policies in the program.
} 
(ii) strengthen land property rights; (iii) create a one-stop window for exporters;

(iv) reinforce the competitiveness of the export sector; and (v) improve the mechanism for reimbursing VAT.

- Public enterprises. The staff noted that a significant factor for the low growth rates of the last decade was the drag caused by the inefficient state-owned enterprise sector. The authorities acknowledged the uneven performance of the state-owned enterprises and confirmed their intention to successfully implement

\begin{tabular}{|lc|}
\hline \multicolumn{2}{|c|}{ Paraguay: Pro-Growth Structural Benchmarks for $\mathbf{2 0 0 7}$} \\
\hline \multicolumn{1}{c}{ Measure } & Date \\
\hline $\begin{array}{l}\text { 1. Implement plan to improve investment climate } \\
\text { 2. Observe result-oriented management contracts } \\
\text { for ANDE, COPACO, ESSAP, INC, \& PETROPAR }\end{array}$ & Sep 2007 \\
\hline Sources: Paraguayan authorities and Fund staff. & \\
\hline
\end{tabular}

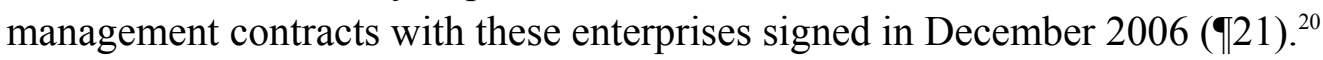

\section{E. Towards an Effective Poverty Reduction Policy}

27. Poverty Alleviation. Poverty remains a serious problem with one in three people living below the poverty line and one in six people living in conditions of extreme poverty. Poverty alleviation programs have had a limited impact in raising living standards of the poor because of institutional limitations and weaknesses in design. Against this backdrop, the authorities are looking to strengthen poverty alleviation programs, with improved targeting and control mechanisms and sufficient budgetary allocations to ensure their implementation. The staff welcomed these intentions and recommended (after consultations with the World Bank and the IDB) that the authorities' efforts to reduce poverty be comprehensive, integrating work in education, health and the provision of basic services like water and electricity. ${ }^{21}$

28. 2007 Poverty Policies. The authorities are determined to continue reducing poverty and viewed economic growth as the most effective contributor to achieve sustainable poverty alleviation, but agreed on the need for direct measures to address the most immediate needs of the

\begin{tabular}{|lc|}
\hline \multicolumn{2}{|c|}{ Paraguay: Poverty Structural Benchmarks for $\mathbf{2 0 0 7}$} \\
\hline \multicolumn{1}{c}{ Measure } & Date \\
\hline $\begin{array}{l}\text { 1. Increase coverage of conditional cash transfer } \\
\text { program to } 15,000 \text { families and establish } \\
\text { mechanisms for evaluation of results. }\end{array}$ & Dec 2007 \\
\hline Sources: Paraguayan authorities and Fund staff. \\
\hline
\end{tabular}

\footnotetext{
${ }^{20}$ The management contracts signed between the government and five large public enterprises (ANDE, COPACO, ESSAP, INC, and PETROPAR) aim at improving efficiency, transparency, communications and quality of services. The contracts are based on simple and clear rules but ambitious objectives that are monitored continuously through a scoreboard approach. There are multiple quantitative and qualitative targets (including commercial, economic, financial, operational and service indicators) that are transparently monitored and leads to quarterly assessments.

${ }^{21}$ See Chapter V in the companion Selected Issues Paper for a detailed description of poverty reduction issues and policies in the program.
} 
population living in extreme poverty. They highlighted the conditional cash transfer program (CCT) as the most important of such measures. They intend to increase the coverage of their CCT program from 8,800 families in 2006 to 15,000 during 2007 ( $(22)$. The staff encouraged the authorities to sharpen their poverty alleviation policy further.

\section{Program Issues}

29. Conditionality. The structure of quantitative performance criteria is the same as last year's program. Conditionality for 2008 will be set at the time of the fifth review (expected for late 2007). The program envisages the implementation of measures associated with benchmarks not met in 2006, as follows:

- Central bank's balance sheet strengthening. Reset the benchmark on the design of a strategy to strengthen the financial position of the Central Bank to June 2007.

- Implications of strategy on central bank strengthening. Reset the benchmark on sending to Congress the budgetary and legal implications of the above mentioned strategy to September 2007.

- $\quad$ Prudential regulations. Change the previous benchmark on implementing regulatory measures to strengthen the financial system (including sending to Congress amendments to the banking law) for a new approach. The new formulation will include three new benchmarks: (i) design a strategy to increase compliance with Basel Core Principles of banking supervision to 80 percent by end-June 2007; (ii) approve a modified resolution $8 / 03$ by end-September 2007, which will become effective by January $1^{\text {st }}, 2008$; and (iii) implement prudential regulations according to the Central Bank's operational plan by end-December 2007.

30. Rephasing. The original schedule of purchases envisaged the completion of three additional purchases by June 2007 associated with the second, third, and fourth program reviews respectively. These reviews have not been completed as scheduled because it took longer than expected to agree on financial policies for 2007. However, one of these purchases (fourth review) was linked to conditionality in 2007 that had not yet been established. For that reason, only two reviews are proposed to be completed, and one purchase needs to be rephased. In particular, it is proposed that the purchase associated with end-March 2007 targets (SDR 6 million) be split by augmenting the purchase associated with end-September 2007 targets (by SDR 31/2 million), and the one associated with the end-December 2007 targets (by SDR $2 \frac{1}{2}$ million). The authorities intend to continue treating the arrangement as precautionary.

31. Access. In view of the significant improvement in their external position, the authorities are considering requesting a reduction in access under this arrangement in the context of the next program review. 
32. Adjustor. An adjustor to the overall balance of the central government equivalent to the direct transfers or interest costs associated with the financial strengthening of the central bank is proposed. ${ }^{22}$ This adjustor does not modify the consolidated public sector fiscal target.

\section{Staff Appraisal}

33. Achievements. After a prolonged decline in per-capita income, Paraguay has implemented critical reforms in the last few years that have reversed the decline and started to reduce poverty. Paraguay's achievements include: (i) the beginning of a growth process with rates well above historical averages; (ii) fiscal discipline and placement of the public debt on a sustainable path; (iii) the rapid buildup of international reserves in the context of a strengthened currency; and (iv) the speedy recovery of the financial system after the 2002 crisis. While these are major accomplishments, Paraguay faces significant challenges such as the need to entrench macroeconomic stability and intensify reforms to establish the conditions for sustained growth, and to address a number of vulnerabilities. The authorities are determined to address these challenges with sound policies and a high degree of ownership.

34. Fiscal policy. The authorities' intention to achieve overall fiscal balance in 2007 and to implement the necessary expenditure cuts with respect to the budget approved by Congress is commendable. The authorities have been able to maintain fiscal discipline despite a difficult political environment and intense expenditure pressures. For the fourth consecutive year, the Ministry of Finance had to resort to the use of a financial plan to conduct fiscal policy given tensions with the approved budget. The situation became more complicated at the end of 2006 after Congress approved a supplementary budget to satisfy demands from the Judicial Branch. To improve the conduct and transparency of fiscal policy, it is therefore important to strengthen the budgetary framework and to establish overall limits that cannot be breached. The gains in tax administration need to be locked in, and the authorities' efforts to design and adopt a modern tax code are welcome.

35. Monetary policy. The proposed monetary program is appropriate and the inflation and reserves objectives of the monetary program are ambitious but achievable. The Central Bank has struck a balance between allowing an appreciation of the guarani and accumulating reserves. Close monitoring of developments will continue to be important, as the authorities will need to respond promptly to signs of inflationary pressures and/or monetary imbalances.

36. Financial system. While significant progress has been made towards enhancing the health of the financial system, the staff is disappointed that the political climate has delayed the much-needed financial sector reform, particularly the strengthening of bank regulation

\footnotetext{
${ }^{22}$ The issuance of government securities to strengthen the financial position of the Central Bank will not have a bearing in the measurement of the fiscal balance of the central government.
} 
through resolution 8/03 and amendments to the banking law that would have reduced identified weaknesses. The authorities' plan to regain momentum in this area is welcome, and they are urged to implement the measures envisaged in their redesigned financial sector reform. With banks having record high profits and record low non-performing loans, this appears to be the best possible time to implement such reforms. These efforts need to be reinforced by the necessary amendments to the banking law, as soon as political circumstances permit.

37. Structural reform. The authorities are encouraged to maintain the momentum of reform and to implement the ambitious reform agenda for 2007 in order to improve productivity and thereby achieve sustained growth. The reform agenda is appropriately multipronged given the challenges ahead. The authorities' determination to implement structural reforms in several areas is commendable and they are advised to maintain the same level of commitment and dynamism in pursuing this agenda.

38. Risks. While there are several international and regional risks, the main risk in the short-run is the pressures to loosen policies in the pre-electoral period. The authorities have been successful in fending off political pressures to increase expenditures in the past, and this effort will need to continue, as the presidential race begins.

39. Reviews. The staff supports completion of second and third reviews under the SBA in light of the good performance and strong ownership of the program.

40. Consultation. The staff proposes that the next Article IV consultation takes place within the 24-month cycle. 


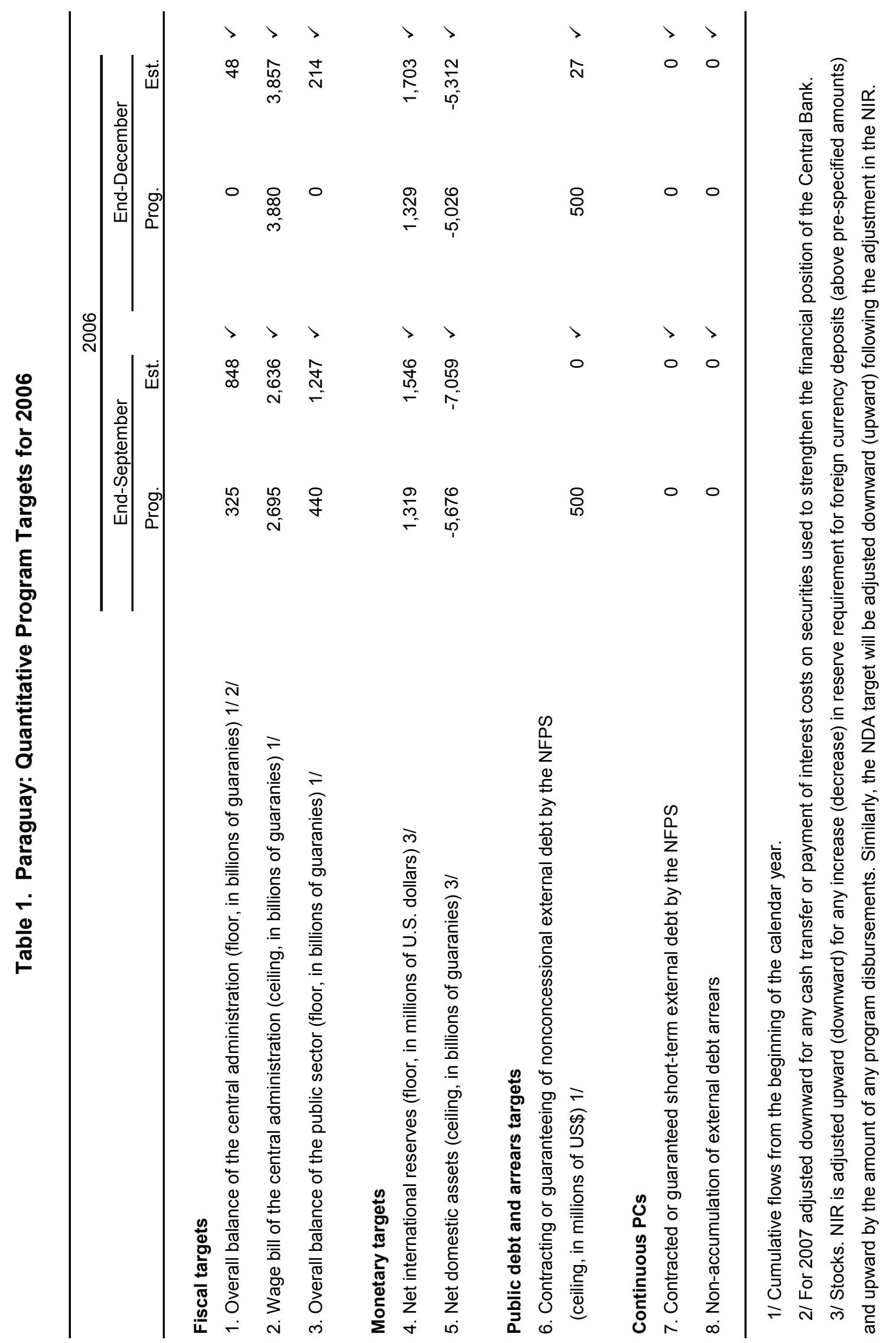


Table 2. Paraguay: Structural Conditionality Under the Program for 2006

\begin{tabular}{|c|c|c|c|c|}
\hline Measure & Conditionality $^{1 /}$ & Timing & & Status \\
\hline \multicolumn{5}{|l|}{ Public Sector Reform } \\
\hline $\begin{array}{l}\text { A. Design of an action plan to develop an effective } \\
\text { commitment control system for the public sector } \\
\text { and rationalize the Treasury account system }\end{array}$ & SB & end-Jun 2006 & $\checkmark$ & Done. \\
\hline B. Preparation of a tax code & $\mathrm{PC}$ & end-Dec 2006 & $\checkmark$ & Done. \\
\hline \multicolumn{5}{|l|}{ Financial Sector Reform } \\
\hline $\begin{array}{l}\text { C. Audited and inspected CAR (fully provisioned) of } 5 \text { percent } \\
\text { for BNF at end-June } 2006\end{array}$ & SB & end-Sep 2006 & $\checkmark$ & Done. \\
\hline $\begin{array}{l}\text { D. Implement regulatory measures outlined in the } \\
\text { banking strategy and put together draft legislation }\end{array}$ & SB & end-Sep 2006 & $\times$ & $\begin{array}{l}\text { Delayed. Replaced by new benchmarks: } \\
\text { (i) design an action plan to strenghthen the } \\
\text { financial sector reform; } \\
\text { (ii) adopt a modified Resolution } 8 / 03 \text {; and } \\
\text { (iii) implement prudential regulation. }\end{array}$ \\
\hline $\begin{array}{l}\text { E. Announce a strategy to strengthen the financial } \\
\text { position of the Central Bank and a timetable for } \\
\text { its implementation }\end{array}$ & SB & end-Dec 2006 & $\times$ & Delayed. To be done by end-June 2007 . \\
\hline $\begin{array}{l}\text { F. Audited and inspected CAR (fully provisioned) of } 10 \text { percent } \\
\text { for BNF at end-December } 2006\end{array}$ & $\mathrm{PC}$ & end-Mar 2007 & $\checkmark$ & Done. \\
\hline $\begin{array}{l}\text { G. Send a bill to Congress that reflects the legal and } \\
\text { budgetary implications of the agreed plan to strengthen } \\
\text { the financial position of the Central Bank }\end{array}$ & SB & mid-Apr 2007 & $\times$ & Delayed. To be done by end-September 2007 \\
\hline \multicolumn{5}{|l|}{ Pro-Growth Reform } \\
\hline H. Design a plan to improve business climate & SB & end-Sep 2006 & $\checkmark$ & Done. \\
\hline $\begin{array}{l}\text { I. Implement result-oriented management contract for } \\
\text { ANDE, COPACO, ESSAP, INC, and PETROPAR }\end{array}$ & SB & end-Dec 2006 & $\checkmark$ & Done. \\
\hline \multicolumn{5}{|l|}{ Social Safety Net } \\
\hline $\begin{array}{l}\text { J. Create a conditional cash transfer mechanism for } 7,000 \\
\text { families living under extreme poverty based on contracts } \\
\text { with beneficiaries }\end{array}$ & SB & end-Dec 2006 & $\checkmark$ & Done. \\
\hline
\end{tabular}

$1 / \mathrm{SB}=$ structural benchmarks; $\mathrm{PC}=$ performance criteria . 
Table 3. Paraguay: Selected Economic and Social Indicators

\begin{tabular}{|c|c|c|c|}
\hline \multicolumn{4}{|c|}{ I. Social and Demographic Indicators } \\
\hline \multirow[t]{2}{*}{ Area (thousand sq. km) } & 407 & Income distribution (2002) & \\
\hline & & By highest 20 percent of households (peI & 61 \\
\hline \multicolumn{2}{|l|}{ Population (2005) } & By lowest 20 percent of households (perc & 2 \\
\hline Total (in millions-2004) & 5.7 & & \\
\hline Rate of increase (percent a year) & 1.9 & Health (2004) & \\
\hline Density (per sq. km.) & 14.1 & Physicians per 1,000 people & 1.1 \\
\hline \multirow[t]{2}{*}{ Unemployment } & 10.9 & Hospital beds per 1,000 people & 1.3 \\
\hline & & Access to a water source (percent) & 80 \\
\hline \multicolumn{2}{|l|}{ Population characteristics (2004) } & Access to a sanitation facility (percent) & 86 \\
\hline Life expectancy at birth (years) & 70.6 & & \\
\hline Crude birth rate (per thousand) & 29.7 & Education (2003; in percent) & \\
\hline Crude death rate (per thousand) & 5.0 & Male literacy rate (percent) & 94 \\
\hline \multirow{3}{*}{ Infant mortality (per thousand live births) } & 21.0 & Female literacy rate (percent) & 92 \\
\hline & & Primary school enrollment (percent) & 106 \\
\hline & & Secondary school enrollment (percent) & 63 \\
\hline
\end{tabular}

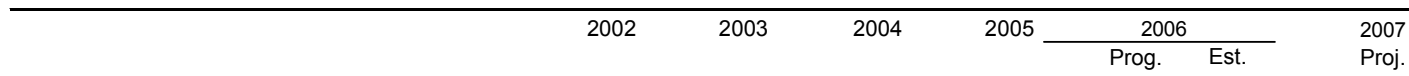

\section{National accounts and prices $1 /$ \\ GDP at current prices \\ GDP at constant prices \\ Per capita GDP (U.S. dollars, thousands) \\ GDP deflator \\ Consumer prices (end-of-period) \\ Real effective exchange rate 2 \\ Average (depreciation -) \\ End-of-period (depreciation -)}

External sector

Exports, f.o.b. (percentage change)

Imports, c.i.f. (percentage change)

Net oil exports and imports

Current account

(in percent of GDP)

Capital accoun

Overall balance

Terms of trade (percentage change)

Savings-investment balance

Gross domestic investment

Private sector

Public sector

Gross national savings

Private sector

Public sector

Public sector

Central government primary balance

Central government overall balance

Consolidated public sector primary balance $3 /$

Consolidated public sector overall balance 3 /

Public sector debt (end-of-year) 4/

External

Domestic

Consolidated public sector debt 5/

Money and credit

Monetary base

M2

M5 5/

Credit to the private sector $6 /$

Velocity of M2

Memorandum items:

International reserves (in millions of U.S. dollars) (In months of imports)

GDP (in billions of guaranies)

Population (millions)

Sources: Paraguayan authorities; and Fund staff estimates.

1/ Revised GDP growth rates and GDP ratios reflects the use of a new national account data recently published by the authorities. However, program GDP ratios were not revised.

2/ INS calculations of real effective exchange rates

$3 /$ Consolidated public sector, including the quasi-fiscal operations of the BCP.

4/ Nonfinancial Public Sector. Based on end-of-period exchange rate conversion of U.S. dollar-denominated debt.

$5 /$ Includes Central Bank Bills (LRMs).

6/ Foreign currency items are valued at a constant exchange rate.

$\begin{array}{rrrrrrr}10.0 & 22.5 & 16.4 & 11.2 & 13.1 & 12.7 & 10.6 \\ 0.0 & 3.8 & 4.1 & 2.9 & 3.5 & 4.0 & 4.0 \\ 0.9 & 1.0 & 1.2 & 1.3 & 1.4 & 1.6 & 1.9 \\ 10.0 & 18.0 & 11.8 & 8.1 & 9.2 & 8.3 & 6.3 \\ 14.6 & 9.3 & 2.8 & 9.9 & 2.5-7.5 & 12.5 & 2.5-7.5 \\ & & & & & & \\ -11.1 & -6.7 & 3.7 & -6.5 & \ldots & 12.5 & \ldots \\ -11.5 & 8.0 & -8.4 & 4.6 & \ldots & 16.7 & \ldots\end{array}$

In millions of U.S. dollars

$\begin{array}{rrrrrrr}-1.6 & 16.8 & 32.0 & 14.9 & 7.6 & 45.8 & 13.3 \\ -14.6 & 14.4 & 27.0 & 22.5 & 5.4 & 50.4 & 10.2 \\ -239 & -327 & -434 & -507 & -519 & -701 & -729 \\ 93 & 125 & 139 & -26 & -180 & -141 & -146 \\ 1.8 & 2.3 & 2.0 & -0.4 & -2.2 & -1.5 & -1.3 \\ 53 & 178 & 38 & 348 & 226 & 320 & 257 \\ -81 & 211 & 270 & 130 & 46 & 402 & 244 \\ 3.0 & 1.5 & 0.0 & -15.6 & 4.3 & -8.4 & 4.8\end{array}$

$\begin{array}{rrrrrrr}18.7 & 19.9 & 20.8 & 19.6 & 23.8 & 21.4 & 22.8 \\ 12.2 & 14.8 & 16.1 & 14.6 & 18.8 & 16.6 & 17.2 \\ 6.4 & 5.1 & 4.7 & 5.0 & 5.0 & 4.8 & 5.6 \\ & & & & & & \\ 20.5 & 22.2 & 22.8 & 19.2 & 21.6 & 19.9 & 21.5 \\ 18.3 & 17.6 & 16.3 & 13.4 & 16.7 & 14.8 & 15.9 \\ 2.2 & 4.6 & 6.5 & 5.8 & 4.9 & 5.1 & 5.6\end{array}$

$\begin{array}{rrrrrrr}-1.9 & 1.0 & 2.7 & 1.9 & 1.0 & 1.5 & 0.9 \\ -2.5 & -0.3 & 2.0 & 0.6 & 0.0 & 0.1 & 0.0 \\ -1.9 & 2.5 & 3.2 & 2.8 & 1.7 & 3.1 & 1.9 \\ -3.8 & 0.0 & 1.8 & 0.9 & 0.0 & 0.4 & 0.0 \\ 71.7 & 52.6 & 45.1 & 37.7 & 34.1 & 27.5 & 25.4 \\ 62.7 & 47.6 & 40.9 & 34.3 & 31.5 & 25.1 & 23.1 \\ 9.0 & 5.0 & 4.2 & 3.4 & 2.6 & 2.4 & 2.3 \\ 74.0 & 55.6 & 48.8 & 42.7 & 38.3 & 33.9 & 32.8\end{array}$

Annual percent change

$\begin{array}{rrrrrrr}-1.0 & 57.7 & 17.6 & 4.3 & 6.0 & 13.0 & 11.1 \\ -2.2 & 24.9 & 24.6 & 16.1 & 8.5 & 15.3 & 12.0 \\ -18.5 & 17.7 & 11.7 & 7.7 & 8.2 & 7.9 & 11.9 \\ -20.9 & -18.4 & 13.9 & 14.1 & 11.9 & 6.8 & 6.3 \\ 7.5 & 8.3 & 7.7 & 7.2 & 7.2 & 7.0 & 6.8 \\ & & & & & & \\ 641 & 983 & 1,168 & 1,297 & 1,317 & 1,703 & 1,920 \\ 2.8 & 3.5 & 3.4 & 2.5 & 3.6 & 3.0 & 3.2 \\ 29,105 & 35,666 & 41,522 & 46,169 & 52,156 & 52,020 & 57,520 \\ 5.5 & 5.6 & 5.7 & 5.8 & 5.9 & 5.9 & 6.0\end{array}$


Table 4. Paraguay: Central Government Operations

\begin{tabular}{|c|c|c|c|c|c|c|c|c|c|c|c|}
\hline & \multirow[t]{3}{*}{2003} & \multirow[t]{3}{*}{2004} & \multirow[t]{3}{*}{2005} & \multicolumn{4}{|c|}{2006} & \multicolumn{4}{|c|}{2007} \\
\hline & & & & \multicolumn{2}{|c|}{ Jan-Sep } & \multicolumn{2}{|c|}{ Jan-Dec } & \multirow{2}{*}{$\frac{\text { Jan-Mar }}{\text { Prel. }}$} & \multirow[t]{2}{*}{ Jan-Jun } & \multirow{2}{*}{$\begin{array}{l}\text { Jan-Sep } \\
\text { Program }\end{array}$} & \multirow[t]{2}{*}{ Jan-Dec } \\
\hline & & & & Prog. & Actual & Prog. & Est. & & & & \\
\hline & & & In billio & of guar & níes & & & & & & \\
\hline Total revenues & 6,001 & 7,637 & 8,419 & 6,779 & 7,232 & 9,358 & 9,588 & 2,472 & 4,809 & 7,533 & 10,450 \\
\hline Tax revenues & 3,676 & 4,929 & 5,471 & 4,274 & 4,697 & 5,877 & 6,295 & 1,534 & 3,208 & 5,043 & 6,954 \\
\hline Income taxes & 624 & 880 & 967 & 533 & 865 & 745 & 1,009 & 166 & 479 & 820 & 1,147 \\
\hline Excises & 704 & 1,000 & 1,007 & 865 & 736 & 1,174 & 1,049 & 352 & 578 & 856 & 1,165 \\
\hline Value added tax & 1,570 & 1,939 & 2,372 & 1,952 & 2,106 & 2,682 & 2,786 & 747 & 1,460 & 2,277 & 3,130 \\
\hline Import Duties & 665 & 904 & 843 & 699 & 682 & 968 & 938 & 200 & 413 & 657 & 910 \\
\hline Other & 113 & 205 & 282 & 225 & 307 & 308 & 513 & 70 & 278 & 432 & 603 \\
\hline Nontax revenues $1 /$ & 2,318 & 2,696 & 2,946 & 2,504 & 2,531 & 3,479 & 3,262 & 937 & 1,600 & 2,488 & 3,493 \\
\hline o/w: Public pension contributions & 364 & 440 & 541 & 417 & 418 & 565 & 560 & 191 & 317 & 477 & 646 \\
\hline Itaipu-Yacyreta & 1,456 & 1,640 & 1,651 & 1,409 & 1,468 & 1,917 & 1,883 & 505 & 811 & 1,258 & 1,755 \\
\hline Capital revenues & 7 & 12 & 2 & 1 & 4 & 2 & 31 & 0 & 2 & 2 & 3 \\
\hline Current expenditures: & 4,981 & 5,363 & 6,231 & 5,019 & 4,951 & 7,125 & 7,138 & 1,678 & 3,636 & 5,557 & 7,905 \\
\hline Wages and salaries & 2,724 & 2,984 & 3,334 & 2,695 & 2,636 & 3,880 & 3,857 & 971 & 2,055 & 3,086 & 4,443 \\
\hline Goods and services & 408 & 447 & 546 & 430 & 437 & 638 & 674 & 79 & 326 & 528 & 784 \\
\hline Interest payments & 489 & 483 & 560 & 441 & 419 & 547 & 519 & 154 & 266 & 423 & 518 \\
\hline Transfers & 1,334 & 1,431 & 1,771 & 1,439 & 1,444 & 2,041 & 2,067 & 470 & 978 & 1,505 & 2,141 \\
\hline Of which: pensions and benefits & 943 & 940 & 1,126 & 906 & 856 & 1,265 & 1,207 & 295 & 627 & 946 & 1,320 \\
\hline Other & 26 & 18 & 19 & 14 & 15 & 19 & 22 & 3 & 10 & 14 & 19 \\
\hline Capital expenditures and net lending & 1,165 & 1,625 & 1,860 & 1,435 & 1,154 & 2,233 & 2,185 & 246 & 990 & 1,647 & 2,544 \\
\hline Statistical discrepancy 2/ & 35 & 181 & -39 & 0 & -280 & 0 & -216 & 51 & 0 & 0 & 0 \\
\hline Overall balance & -110 & 830 & 289 & 325 & 848 & 0 & 48 & 600 & 184 & 330 & 0 \\
\hline Financing & 110 & -830 & -289 & -325 & -848 & 0 & -48 & -600 & -184 & -330 & 0 \\
\hline External debt (increase + ) & 588 & 103 & -295 & -99 & -257 & 28 & -122 & -30 & -59 & -76 & 89 \\
\hline Disbursements & 1,151 & 763 & 658 & 795 & 493 & 1,192 & 832 & 100 & 416 & 694 & 1,040 \\
\hline Amortizations & 563 & 660 & 953 & 894 & 749 & 1,164 & 954 & 130 & 475 & 771 & 950 \\
\hline Domestic bonds (increase +) & -58 & -78 & -137 & -208 & -28 & -208 & 147 & 0 & -80 & -91 & 2 \\
\hline Net credit from the banking system $1 /$ & -308 & -162 & -44 & 83 & -572 & 190 & -373 & -292 & -45 & -162 & -91 \\
\hline Net credit from Central Bank & -343 & -114 & 55 & 83 & -606 & 190 & -466 & -100 & -45 & -162 & -91 \\
\hline Net credit from commercial banks & 35 & -48 & -99 & 0 & 34 & 0 & 93 & -192 & 0 & 0 & 0 \\
\hline Other & -111 & -693 & 188 & -100 & 10 & -10 & 300 & -277 & 0 & 0 & 0 \\
\hline & & & In per & :ent of $\mathrm{G}$ & & & & & & & \\
\hline Total revenues & 16.8 & 18.4 & 18.2 & 13.0 & 13.9 & 17.9 & 18.4 & 4.3 & 8.4 & 13.1 & 18.2 \\
\hline Tax revenues: & 10.3 & 11.9 & 11.8 & 8.2 & 9.0 & 11.3 & 12.1 & 2.7 & 5.6 & 8.8 & 12.1 \\
\hline Income taxes & 1.7 & 2.1 & 2.1 & 1.0 & 1.7 & 1.4 & 1.9 & 0.3 & 0.8 & 1.4 & 2.0 \\
\hline Excises & 2.0 & 2.4 & 2.2 & 1.7 & 1.4 & 2.3 & 2.0 & 0.6 & 1.0 & 1.5 & 2.0 \\
\hline Value added tax & 4.4 & 4.7 & 5.1 & 3.7 & 4.0 & 5.1 & 5.4 & 1.3 & 2.5 & 4.0 & 5.4 \\
\hline Import duties & 1.9 & 2.2 & 1.8 & 1.3 & 1.3 & 1.9 & 1.8 & 0.3 & 0.7 & 1.1 & 1.6 \\
\hline Other & 0.3 & 0.5 & 0.6 & 0.4 & 0.6 & 0.6 & 1.0 & 0.1 & 0.5 & 0.8 & 1.0 \\
\hline Nontax revenues $2 /$ & 6.5 & 6.5 & 6.4 & 4.8 & 4.9 & 6.7 & 6.3 & 1.6 & 2.8 & 4.3 & 6.1 \\
\hline$O / W$ : public pension contributions & 1.0 & 1.1 & 1.2 & 0.8 & 0.8 & 1.1 & 1.1 & 0.3 & 0.6 & 0.8 & 1.1 \\
\hline 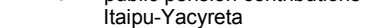 & 4.1 & 3.9 & 3.6 & 2.7 & 2.8 & 3.7 & 3.6 & 0.9 & 1.4 & 2.2 & 3.1 \\
\hline Capital revenues & 0.0 & 0.0 & 0.0 & 0.0 & 0.0 & 0.0 & 0.1 & 0.0 & 0.0 & 0.0 & 0.0 \\
\hline Current expenditures & 14.0 & 12.9 & 13.5 & 9.6 & 9.5 & 13.7 & 13.7 & 2.9 & 6.3 & 9.7 & 13.7 \\
\hline Wages and salaries & 7.6 & 7.2 & 7.2 & 5.2 & 5.1 & 7.4 & 7.4 & 1.7 & 3.6 & 5.4 & 7.7 \\
\hline Goods and services & 1.1 & 1.1 & 1.2 & 0.8 & 0.8 & 1.2 & 1.3 & 0.1 & 0.6 & 0.9 & 1.4 \\
\hline Interest payments & 1.4 & 1.2 & 1.2 & 0.8 & 0.8 & 1.0 & 1.0 & 0.3 & 0.5 & 0.7 & 0.9 \\
\hline Transfers & 3.7 & 3.4 & 3.8 & 2.8 & 2.8 & 3.9 & 4.0 & 0.8 & 1.7 & 2.6 & 3.7 \\
\hline Capital expenditures and net lending & 3.3 & 3.9 & 4.0 & 2.8 & 2.2 & 4.3 & 4.2 & 0.4 & 1.7 & 2.9 & 4.4 \\
\hline Statistical discrepancy $3 /$ & 0.1 & 0.4 & -0.1 & 0.0 & -0.5 & 0.0 & -0.4 & 0.1 & 0.0 & 0.0 & 0.0 \\
\hline Overall balance & -0.3 & 2.0 & 0.6 & 0.6 & 1.6 & 0.0 & 0.1 & 1.0 & 0.3 & 0.6 & 0.0 \\
\hline Financing & 0.3 & -2.0 & -0.6 & -0.6 & -1.6 & 0.0 & -0.1 & -1.0 & -0.3 & -0.6 & 0.0 \\
\hline External debt (increase +) & 1.6 & 0.2 & -0.6 & -0.2 & -0.5 & 0.1 & -0.2 & -0.1 & -0.1 & -0.1 & 0.2 \\
\hline Disbursements & 3.2 & 1.8 & 1.4 & 1.5 & 0.9 & 2.3 & 1.6 & 0.2 & 0.7 & 1.2 & 1.8 \\
\hline Amortizations & 1.6 & 1.6 & 2.1 & 1.7 & 1.4 & 2.2 & 1.8 & 0.2 & 0.8 & 1.3 & 1.7 \\
\hline Domestic bonds (increase + ) & -0.2 & -0.2 & -0.3 & -0.4 & -0.1 & -0.4 & 0.3 & 0.0 & -0.1 & -0.2 & 0.0 \\
\hline Net credit from the banking system & -0.9 & -0.4 & -0.1 & 0.2 & -1.1 & 0.4 & -0.7 & -0.5 & -0.1 & -0.3 & -0.2 \\
\hline Other & -0.3 & -1.7 & 0.4 & 0.0 & 0.0 & 0.0 & 0.6 & 0.0 & 0.0 & 0.0 & 0.0 \\
\hline Memorandum Item: & & & & & & & & & & & \\
\hline Primary balance & 1.0 & 2.7 & 1.9 & 1.5 & 3.0 & 1.0 & 1.5 & 1.2 & 0.8 & 1.3 & 0.9 \\
\hline Balance of the Caja Fiscal 4/ & -1.6 & -1.2 & -1.3 & -0.9 & -0.8 & -1.3 & -1.2 & -0.2 & -0.5 & -0.8 & -1.2 \\
\hline
\end{tabular}


Table 5. Paraguay: Operations of the Consolidated Public Sector 1/

\begin{tabular}{|c|c|c|c|c|c|c|c|c|c|c|c|}
\hline & \multirow[t]{3}{*}{2003} & \multirow[t]{3}{*}{2004} & \multirow[t]{3}{*}{2005} & \multicolumn{4}{|c|}{2006} & \multicolumn{4}{|c|}{2007} \\
\hline & & & & \multicolumn{2}{|c|}{ Jan-Sep } & \multicolumn{2}{|c|}{ Jan-Dec } & \multirow{2}{*}{$\frac{\text { Jan-Mar }}{\text { Prel. }}$} & \multirow[t]{2}{*}{ Jan-Jun } & \multirow{2}{*}{$\frac{\text { Jan-Sep }}{\text { Program }}$} & \multirow[t]{2}{*}{ Jan-Dec } \\
\hline & & & & Prog. & Actual & Prog. & Est. & & & & \\
\hline \multicolumn{12}{|c|}{ In billion of guaranies } \\
\hline Revenue & 7,450 & 8,959 & 10,114 & 8,205 & 8,724 & 11,261 & 11,564 & 2,995 & 5,858 & 9,088 & 12,702 \\
\hline Tax revenue & 3,676 & 4,936 & 5,483 & 4,284 & 4,713 & 5,890 & 6,314 & 1,537 & 3,215 & 5,054 & 6,975 \\
\hline Nontax revenue and grants & 3,617 & 4,010 & 4,596 & 3,895 & 4,007 & 5,335 & 5,210 & 1,456 & 2,632 & 4,022 & 5,714 \\
\hline Capital revenue & 157 & 14 & 35 & 26 & 4 & 36 & 40 & 1 & 11 & 11 & 13 \\
\hline Current expenditure & 6,247 & 6,959 & 7,908 & 6,550 & 6,233 & 9,275 & 9,060 & 2,071 & 4,519 & 6,958 & 10,157 \\
\hline Wages and salaries & 3,290 & 3,634 & 4,087 & 3,282 & 3,186 & 4,730 & 4,665 & 1,160 & 2,427 & 3,632 & 5,271 \\
\hline Goods and services & 634 & 755 & 994 & 814 & 667 & 1,161 & 1,054 & 130 & 489 & 814 & 1,235 \\
\hline Interest payments & 728 & 678 & 751 & 698 & 645 & 911 & 858 & 255 & 480 & 743 & 1,103 \\
\hline Transfers & 1,544 & 1,699 & 2,048 & 1,690 & 1,713 & 2,378 & 2,449 & 521 & 1,097 & 1,723 & 2,470 \\
\hline Other & 51 & 193 & 27 & 65 & 22 & 95 & 33 & 5 & 25 & 45 & 77 \\
\hline Capital expenditure and net lending & 1,819 & 1,956 & 2,306 & 1,714 & 1,332 & 2,605 & 2,477 & 415 & 1,398 & 2,236 & 3,247 \\
\hline Of which: capital expenditure & 1,850 & 2,189 & 2,550 & 1,874 & 1,463 & 2,818 & 2,677 & 444 & 1,468 & 2,375 & 3,468 \\
\hline Primary balance & 909 & 1,315 & 1,298 & 1,138 & 2,472 & 911 & 1,594 & 859 & 682 & 1,203 & 1,103 \\
\hline Public enterprises' operating surplus & 796 & 593 & 646 & 499 & 669 & 619 & 708 & 95 & 260 & 565 & 702 \\
\hline Statistical discrepancy 2/ & -198 & 119 & -132 & 0 & -561 & 0 & -502 & 0 & 0 & 0 & 0 \\
\hline Overall balance & -17 & 756 & 414 & 440 & 1,267 & 0 & 234 & 604 & 202 & 459 & 0 \\
\hline Financing & 17 & -756 & -414 & -440 & $-1,267$ & 0 & -234 & -604 & -202 & -459 & 0 \\
\hline External financing net & 459 & -42 & -445 & -165 & -435 & -43 & -257 & -149 & -170 & -240 & -134 \\
\hline Disbursements & 1,273 & 808 & 771 & 858 & 493 & 1,287 & 939 & 153 & 416 & 694 & 1,040 \\
\hline Amortizations & 814 & 850 & 1,216 & 1,022 & 927 & 1,329 & 1,196 & 302 & 586 & 934 & 1,174 \\
\hline Domestic financing net & -24 & 72 & -202 & -144 & -951 & 95 & -297 & -177 & -32 & -219 & 134 \\
\hline Bond financing & -58 & -78 & -137 & -208 & -28 & -208 & 147 & 0 & -80 & -91 & 2 \\
\hline Net credit from the banking system & -356 & -183 & -176 & -181 & -976 & -73 & -549 & -197 & -59 & -317 & -296 \\
\hline Quasifiscal deficit financing & 390 & 333 & 112 & 245 & 54 & 376 & 105 & 20 & 107 & 190 & 429 \\
\hline Other & -417 & -786 & 232 & -132 & 119 & -53 & 320 & -277 & 0 & 0 & 0 \\
\hline \multicolumn{12}{|c|}{ In percent of GDP } \\
\hline Revenue & 20.9 & 21.6 & 21.9 & 15.7 & 16.8 & 21.6 & 22.2 & 5.2 & 10.2 & 15.8 & 22.1 \\
\hline Tax revenue & 10.3 & 11.9 & 11.9 & 8.2 & 9.1 & 11.3 & 12.1 & 2.7 & 5.6 & 8.8 & 12.1 \\
\hline Nontax revenue and grants & 10.1 & 9.7 & 10.0 & 7.5 & 7.7 & 10.2 & 10.0 & 2.5 & 4.6 & 7.0 & 9.9 \\
\hline Capital revenue & 0.4 & 0.0 & 0.1 & 0.1 & 0.0 & 0.1 & 0.1 & 0.0 & 0.0 & 0.0 & 0.0 \\
\hline Current expenditure & 17.5 & 16.8 & 17.1 & 12.6 & 12.0 & 17.8 & 17.4 & 3.6 & 7.9 & 12.1 & 17.7 \\
\hline Wages and salaries & 9.2 & 8.8 & 8.9 & 6.3 & 6.1 & 9.1 & 9.0 & 2.0 & 4.2 & 6.3 & 9.2 \\
\hline Goods and services & 1.8 & 1.8 & 2.2 & 1.6 & 1.3 & 2.2 & 2.0 & 0.2 & 0.9 & 1.4 & 2.1 \\
\hline Interest payments & 2.0 & 1.6 & 1.6 & 1.3 & 1.2 & 1.7 & 1.6 & 0.4 & 0.8 & 1.3 & 1.9 \\
\hline Transfers & 4.3 & 4.1 & 4.4 & 3.2 & 3.3 & 4.6 & 4.7 & 0.9 & 1.9 & 3.0 & 4.3 \\
\hline Other & 0.1 & 0.5 & 0.1 & 0.1 & 0.0 & 0.2 & 0.1 & 0.0 & 0.0 & 0.1 & 0.1 \\
\hline Capital expenditure and net lending & 5.1 & 4.7 & 5.0 & 3.3 & 2.6 & 5.0 & 4.8 & 0.7 & 2.4 & 3.9 & 5.6 \\
\hline Of which: capital expenditure & 5.1 & 4.9 & 5.0 & 3.3 & 2.6 & 5.0 & 4.8 & 0.7 & 2.4 & 3.9 & 5.6 \\
\hline Public enterprises' operating surplus & 2.2 & 1.4 & 1.4 & 1.0 & 1.3 & 1.2 & 1.4 & 0.2 & 0.5 & 1.0 & 1.2 \\
\hline Statistical discrepancy $2 /$ & -0.6 & 0.3 & -0.3 & 0.0 & -1.1 & 0.0 & -1.0 & 0.0 & 0.0 & 0.0 & 0.0 \\
\hline Overall balance & 0.0 & 1.8 & 0.9 & 0.8 & 2.4 & 0.0 & 0.4 & 1.0 & 0.4 & 0.8 & 0.0 \\
\hline Financing & 0.0 & -1.8 & -0.9 & -0.8 & -2.4 & 0.0 & -0.4 & -1.0 & -0.4 & -0.8 & 0.0 \\
\hline External financing net & 1.3 & -0.1 & -1.0 & -0.3 & -0.8 & -0.1 & -0.5 & -0.3 & -0.3 & -0.4 & -0.2 \\
\hline Disbursements & 3.6 & 1.9 & 1.7 & 1.6 & 0.9 & 2.5 & 1.8 & 0.3 & 0.7 & 1.2 & 1.8 \\
\hline Amortizations & 2.3 & 2.0 & 2.6 & 2.0 & 0.0 & 2.5 & 2.3 & 0.0 & 0.0 & 0.0 & 2.0 \\
\hline Domestic financing net & -0.1 & 0.2 & -0.4 & -0.3 & -1.8 & 0.2 & -0.6 & -0.3 & -0.1 & -0.4 & 0.2 \\
\hline Of which: quasifiscal deficit financing & 1.1 & 0.8 & 0.2 & 0.5 & 0.1 & 0.7 & 0.2 & 0.0 & 0.2 & 0.3 & 0.7 \\
\hline Other & -1.2 & -1.9 & 0.5 & -0.3 & 0.2 & -0.1 & 0.6 & -0.5 & 0.0 & 0.0 & 0.0 \\
\hline \multicolumn{12}{|l|}{ Memorandum item: } \\
\hline Primary balance & 2.5 & 3.2 & 2.8 & 2.2 & 4.8 & 1.7 & 3.1 & 1.5 & 1.2 & 2.1 & 1.9 \\
\hline
\end{tabular}

Sources: Ministry of Finance and Fund staff estimates.

1/ Public sector comprises only the nonfinancial public sector and the Central Bank.

2/ Measurement error to reconcile above the line estimate with estimates of the fiscal balance from the financing side. 
Table 6. Paraguay: Summary Accounts of the Central Bank (In billions of guaranies; end-of-period; valued at constant exchange rate)

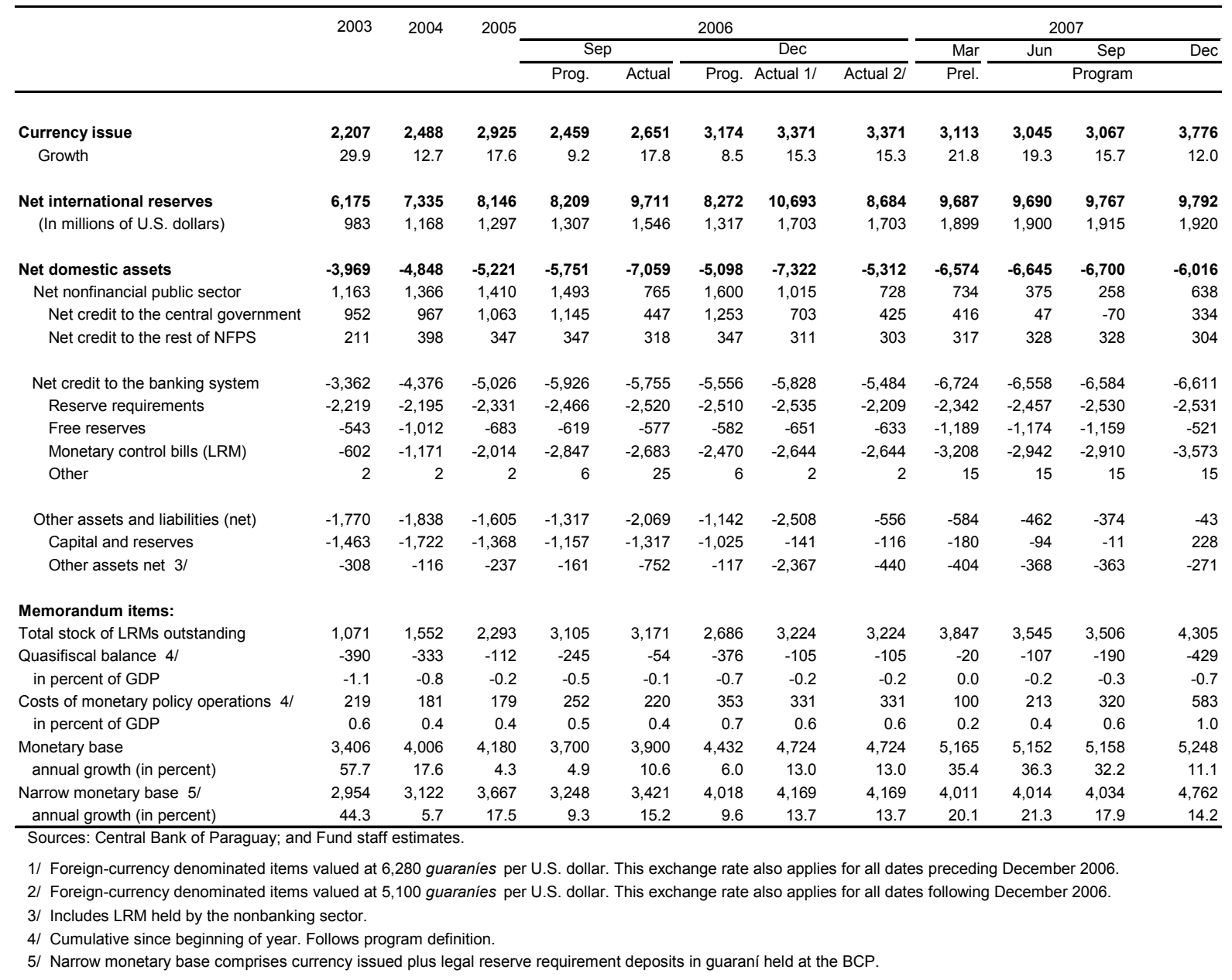


Table 7. Paraguay: Summary Accounts of the Banking System

(In billions of guaranies; end-of-period; valued at constant exchange rate)

\begin{tabular}{|c|c|c|c|c|c|c|c|c|c|c|c|c|}
\hline & \multirow[t]{3}{*}{2003} & \multirow[t]{3}{*}{2004} & \multirow[t]{3}{*}{2005} & \multicolumn{5}{|c|}{2006} & \multicolumn{4}{|c|}{2007} \\
\hline & & & & \multicolumn{2}{|c|}{ Sep } & \multicolumn{3}{|c|}{ Dec } & \multirow{2}{*}{$\frac{\text { Mar }}{\text { Prel. }}$} & Jun & \multirow{2}{*}{$\begin{array}{r}\text { Sep } \\
\text { Program }\end{array}$} & \multirow[t]{2}{*}{$\mathrm{Dec}$} \\
\hline & & & & Prog. & Actual & Prog. & Actual 1/ & Actual 2/ & & & & \\
\hline \multicolumn{13}{|c|}{ I. Central Bank } \\
\hline Net international reserves & 6,175 & 7,335 & 8,146 & 8,209 & 9,711 & 8,272 & 10,693 & 8,684 & 9,687 & 9,690 & 9,767 & 9,792 \\
\hline (in millions of U.S. dollars) & 983 & 1,168 & 1,297 & 1,307 & 1,546 & 1,317 & 1,703 & 1,703 & 1,899 & 1,900 & 1,915 & 1,920 \\
\hline Net domestic assets & $-3,969$ & $-4,848$ & $-5,221$ & $-5,751$ & $-7,059$ & $-5,098$ & $-7,322$ & $-5,312$ & $-6,574$ & $-6,645$ & $-6,700$ & $-6,016$ \\
\hline Credit to public sector, net & 1,163 & 1,366 & 1,410 & 1,493 & 765 & 1,600 & 1,015 & 728 & 734 & 375 & 258 & 638 \\
\hline Credit to banking system, net $3 /$ & $-2,760$ & $-3,205$ & $-3,012$ & $-3,079$ & $-3,072$ & $-3,086$ & $-3,185$ & $-2,840$ & $-3,516$ & $-3,616$ & $-3,673$ & $-3,038$ \\
\hline Central bank securites & $-1,071$ & $-1,552$ & $-2,293$ & $-3,105$ & $-3,171$ & $-2,686$ & $-3,224$ & $-3,224$ & $-3,847$ & $-3,545$ & $-3,506$ & $-4,305$ \\
\hline Other & $-1,301$ & $-1,457$ & $-1,326$ & $-1,060$ & $-1,582$ & -926 & $-1,928$ & 24 & 55 & 141 & 222 & 689 \\
\hline Currency issue & 2,207 & 2,488 & 2,925 & 2,459 & 2,651 & 3,174 & 3,371 & 3,371 & 3,113 & 3,045 & 3,067 & 3,776 \\
\hline \multicolumn{13}{|c|}{ II. Monetary Survey } \\
\hline Net foreign assets & 8,405 & 9,478 & 10,028 & 10,327 & 12,034 & 10,353 & 12,491 & 10,140 & 11,224 & 11,259 & 11,394 & 11,469 \\
\hline (in millions of U.S. dollars) & 1,338 & 1,509 & 1,597 & 1,644 & 1,916 & 1,649 & 1,989 & 1,988 & 2,201 & 2,208 & 2,234 & 2,249 \\
\hline Net domestic assets & 2,152 & 2,313 & 2,671 & 2,589 & 1,519 & 3,391 & 2,398 & 3,564 & 3,024 & 2,908 & 2,731 & 3,859 \\
\hline Credit to the public sector & 699 & 531 & 237 & -128 & -744 & 27 & -188 & -411 & -795 & $-1,165$ & $-1,424$ & -700 \\
\hline Credit to the private sector & 5,081 & 5,788 & 6,601 & 6,793 & 7,216 & 7,389 & 7,760 & 7,051 & 7,292 & 7,155 & 7,282 & 7,496 \\
\hline Other & $-3,628$ & $-4,006$ & $-4,167$ & $-4,075$ & $-4,953$ & $-4,026$ & $-5,174$ & $-3,077$ & $-3,474$ & $-3,082$ & $-3,128$ & $-2,937$ \\
\hline Broad Liquidity (M4) & 10,558 & 11,791 & 12,699 & 12,916 & 13,553 & 13,744 & 14,890 & 13,704 & 14,247 & 14,166 & 14,124 & 15,328 \\
\hline Bonds and issued securities & 31 & 0 & 0 & 0 & 0 & 0 & 0 & 0 & 0 & 0 & 0 & 0 \\
\hline Other monetary liabilities & 9 & 125 & 85 & 60 & 60 & 93 & 32 & 26 & 20 & 55 & 53 & 28 \\
\hline Central bank securities with private sector & 469 & 381 & 280 & 310 & 487 & 269 & 580 & 580 & 639 & 603 & 596 & 732 \\
\hline Broad liquidity (M3) & 10,047 & 11,285 & 12,334 & 12,545 & 13,007 & 13,383 & 14,278 & 13,098 & 13,588 & 13,509 & 13,475 & 14,568 \\
\hline Foreign currency deposits & 5,253 & 5,310 & 5,396 & 5,970 & 6,310 & 5,855 & 6,280 & 5,100 & 5,370 & 5,497 & 5,588 & 5,610 \\
\hline Money and quasi-money (M2) & 4,794 & 5,974 & 6,938 & 6,575 & 6,697 & 7,528 & 7,998 & 7,998 & 8,218 & 8,012 & 7,886 & 8,958 \\
\hline Quasi-money & 1,208 & 1,482 & 1,472 & 1,703 & 1,566 & 1,597 & 1,668 & 1,668 & 1,868 & 1,840 & 1,850 & 1,869 \\
\hline Money (M1) & 3,587 & 4,492 & 5,466 & 4,872 & 5,131 & 5,930 & 6,330 & 6,330 & 6,350 & 6,172 & 6,037 & 7,089 \\
\hline \multicolumn{13}{|c|}{ Annual percentage change } \\
\hline M0 (Currency issued) & 29.9 & 12.7 & 17.6 & 9.2 & 17.8 & 8.5 & 15.3 & 15.3 & 21.8 & 19.3 & 15.7 & 12.0 \\
\hline Credit to the private sector & -18.4 & 13.9 & 14.1 & 16.8 & 24.0 & 11.9 & 17.6 & 6.8 & 10.0 & 5.9 & 0.9 & 6.3 \\
\hline M1 & 35.8 & 25.2 & 21.7 & 9.7 & 15.5 & 8.5 & 15.8 & 15.8 & 25.1 & 22.9 & 17.6 & 12.0 \\
\hline M2 & 24.9 & 24.6 & 16.1 & 9.8 & 11.8 & 8.5 & 15.3 & 15.3 & 23.4 & 23.2 & 17.8 & 12.0 \\
\hline M3 & 17.7 & 12.3 & 9.3 & 8.4 & 12.4 & 8.5 & 15.8 & 6.2 & 9.4 & 5.8 & 3.6 & 11.2 \\
\hline Of which: foreign currency deposits & 11.8 & 1.1 & 1.6 & 7.0 & 13.1 & 8.5 & 16.4 & -5.5 & -6.8 & -12.2 & -11.4 & 10.0 \\
\hline \multicolumn{13}{|l|}{ Memorandum items: } \\
\hline $\begin{array}{l}\text { Ratio of foreign currency deposits } \\
\text { to M3 (percent) }\end{array}$ & 52.3 & 47.1 & 43.7 & 47.6 & 48.5 & 43.7 & 44.0 & 38.9 & 39.5 & 40.7 & 41.5 & 38.5 \\
\hline \multicolumn{13}{|l|}{ Ratio of foreign currency deposits } \\
\hline to private sector deposits in banks (percent) & 63.5 & 57.1 & 54.6 & 56.9 & 58.5 & 54.6 & 55.4 & 50.3 & 49.1 & 50.6 & 51.5 & 49.8 \\
\hline
\end{tabular}

Sources: Central Bank of Paraguay; and Fund staff estimates.

1/ Foreign-currency denominated items valued at 6,280 guaranies per U.S. dollar. This exchange rate also applies for all dates preceding December 2006. 2/ Foreign-currency denominated items valued at 5,100 guaraníes per U.S. dollar. This exchange rate also applies for all dates following December 2006.

3/ Reflects debt write-offs of central bank credit to commercial banks during 1997 and 1998. 
Table 8. Paraguay: Banking System Indicators

\begin{tabular}{|c|c|c|c|c|c|}
\hline & 2002 & 2003 & 2004 & 2005 & 2006 \\
\hline \multicolumn{6}{|c|}{ I. Total banking system $(I I+|I I+| V+V)$} \\
\hline Share in assets & 100.0 & 100.0 & 100.0 & 100.0 & 100.0 \\
\hline Capital adequacy ratio (percent) $1 /$ & 17.9 & 20.9 & 20.5 & 20.4 & 20.1 \\
\hline NPLs/total loans & 19.7 & 20.6 & 10.8 & 6.6 & 3.3 \\
\hline Provisions/NPLs & 46.6 & 54.8 & 54.6 & 57.7 & 59.1 \\
\hline Rate of return on assets (ROA) & 1.0 & 0.4 & 1.7 & 2.1 & 3.0 \\
\hline Rate of return on equity (ROE) & 9.0 & 4.5 & 18.3 & 22.6 & 31.7 \\
\hline Liquid assets/total assets $2 /$ & 25.1 & 32.6 & 30.8 & 26.6 & 23.3 \\
\hline Foreign exchange deposits/total deposits & 68.6 & 61.7 & 55.0 & 52.7 & 49.1 \\
\hline \multicolumn{6}{|c|}{ II. Total foreign-owned banks } \\
\hline Share in assets & 48.4 & 47.4 & 35.8 & 31.3 & 29.1 \\
\hline Capital adequacy ratio (percent) 1/ & 17.6 & 20.4 & 26.0 & 27.2 & 25.5 \\
\hline NPLs/total loans & 20.1 & 20.8 & 11.0 & 6.4 & 3.6 \\
\hline Provisions/NPLs & 57.5 & 64.2 & 71.2 & 63.4 & 68.6 \\
\hline Rate of return on assets (ROA) & 1.6 & 0.1 & 1.4 & 1.4 & 2.2 \\
\hline Rate of return on equity (ROE) & 15.0 & 1.2 & 12.0 & 11.3 & 18.6 \\
\hline Liquid assets/total assets $2 /$ & 27.1 & 29.8 & 25.4 & 29.0 & 24.5 \\
\hline Foreign exchange deposits/total deposits & 71.1 & 65.6 & 65.2 & 65.1 & 61.2 \\
\hline \multicolumn{6}{|c|}{ III. Total majority-owned foreign banks } \\
\hline Share in assets & 33.2 & 37.2 & 45.2 & 48.0 & 51.4 \\
\hline Capital adequacy ratio (percent) $1 /$ & 19.9 & 21.0 & 17.7 & 17.8 & 17.4 \\
\hline NPLs/total loans & 10.4 & 12.3 & 3.7 & 2.3 & 1.8 \\
\hline Provisions/NPLs & 43.8 & 52.1 & 56.9 & 87.2 & 83.0 \\
\hline Rate of return on assets (ROA) & 1.4 & 1.3 & 2.2 & 3.0 & 3.9 \\
\hline Rate of return on equity (ROE) & 13.4 & 15.5 & 25.8 & 35.3 & 45.8 \\
\hline Liquid assets/total assets $2 /$ & 26.2 & 35.3 & 28.8 & 22.6 & 18.5 \\
\hline Foreign exchange deposits/total deposits & 70.7 & 62.3 & 53.8 & 51.7 & 48.8 \\
\hline \multicolumn{6}{|c|}{ IV. Total domestic-owned private banks } \\
\hline Share in assets & 10.4 & 7.4 & 8.2 & 9.4 & 9.9 \\
\hline Capital adequacy ratio (percent) $1 /$ & 13.6 & 14.1 & 13.3 & 13.4 & 15.6 \\
\hline NPLs/total loans & 8.8 & 2.9 & 2.1 & 0.8 & 1.4 \\
\hline Provisions/NPLs & 18.7 & 46.2 & 70.3 & 77.1 & 78.6 \\
\hline Rate of return on assets (ROA) & 1.1 & 1.6 & 2.0 & 2.2 & 2.9 \\
\hline Rate of return on equity (ROE) & 14.3 & 21.1 & 28.1 & 30.8 & 35.9 \\
\hline Liquid assets/total assets $2 /$ & 18.3 & 38.8 & 38.1 & 34.0 & 34.6 \\
\hline Foreign exchange deposits/total deposits & 62.6 & 60.7 & 57.6 & 54.7 & 51.5 \\
\hline \multicolumn{6}{|c|}{ V. National Development Bank (BNF) } \\
\hline Share in assets & 8.0 & 8.0 & 10.7 & 11.3 & 9.5 \\
\hline Capital adequacy ratio (percent) $1 /$ & 18.8 & 30.0 & 25.0 & 26.5 & 32.2 \\
\hline NPLs/total loans & 56.2 & 56.2 & 48.9 & 40.3 & 19.4 \\
\hline Provisions/NPLs & 39.6 & 47.6 & 43.1 & 45.1 & 31.6 \\
\hline Rate of return on assets (ROA) & -4.7 & -2.8 & 0.5 & 0.4 & 0.5 \\
\hline Rate of return on equity (ROE) & -27.3 & -18.7 & 6.8 & 5.3 & 5.7 \\
\hline Liquid assets/total assets $2 /$ & 17.3 & 30.7 & 52.0 & 31.2 & 33.8 \\
\hline Foreign exchange deposits/total deposits & 42.5 & 32.7 & 23.6 & 20.6 & 13.1 \\
\hline
\end{tabular}

Source: Superintendency of Banks.

1/ Definition of CAR does not fully comply with international standards.

2/ Liquid assets are calculated as the sum of cash, reserves, accounts in banks and lending in interbank market. 
Table 9. Paraguay: Balance of Payments

(In millions of U.S. dollars)

\begin{tabular}{|c|c|c|c|c|c|c|c|c|c|c|c|c|}
\hline & \multirow{4}{*}{$\begin{array}{r}2003 \\
125\end{array}$} & \multirow{4}{*}{$\begin{array}{r}2004 \\
139\end{array}$} & \multirow{4}{*}{$\begin{array}{r}2005 \\
-26\end{array}$} & \multicolumn{4}{|c|}{2006} & \multicolumn{5}{|c|}{2007} \\
\hline & & & & \multicolumn{2}{|c|}{ Jan-Sep } & \multicolumn{2}{|c|}{ Jan-Dec } & \multirow{3}{*}{$\frac{\text { Jan-Mar }}{-92}$} & \multirow{2}{*}{$\frac{\text { Apr-Jun }}{\mathrm{P}}$} & \multirow{2}{*}{$\frac{\text { Jul-Sep }}{\text { rojections }}$} & \multirow[t]{2}{*}{ Oct-Dec } & \multirow[t]{2}{*}{ Year } \\
\hline & & & & Prog. & Actual & Prog. & Est. & & & & & \\
\hline & & & & 132 & -81 & -180 & -141 & & 73 & -25 & -102 & -146 \\
\hline Trade balance & -280 & -248 & -520 & -196 & -569 & -599 & -935 & -217 & -102 & -205 & -361 & -886 \\
\hline Exports & 2,163 & 2,854 & 3,280 & 2,531 & 3,489 & 3,264 & 4,781 & 1,447 & 1,386 & 1,425 & 1,156 & 5,414 \\
\hline Imports & $-2,443$ & $-3,102$ & $-3,800$ & $-2,726$ & $-4,059$ & $-3,863$ & $-5,715$ & $-1,664$ & $-1,489$ & $-1,630$ & $-1,517$ & $-6,300$ \\
\hline Services (net) & 245 & 327 & 348 & 156 & 255 & 183 & 364 & 64 & 72 & 87 & 112 & 336 \\
\hline Factor income & -8 & -138 & -77 & -4 & 2 & -7 & 57 & 3 & 39 & 5 & 31 & 79 \\
\hline Transfers & 165 & 194 & 223 & 175 & 232 & 243 & 373 & 59 & 64 & 87 & 116 & 325 \\
\hline Capital and financial account & 178 & 38 & 348 & -101 & 59 & 226 & 320 & 155 & -72 & 67 & 107 & 257 \\
\hline General government & 77 & -26 & -107 & -11 & -35 & 12 & 10 & -29 & 18 & -4 & 32 & 18 \\
\hline Disbursements & 213 & 139 & 107 & 126 & 87 & 188 & 184 & 30 & 52 & 55 & 66 & 202 \\
\hline Amortization & -130 & -133 & -175 & -143 & -131 & -185 & -169 & -59 & -34 & -58 & -34 & -185 \\
\hline Other & -6 & -32 & -39 & 6 & 9 & 9 & -5 & 0 & 0 & 0 & 0 & 0 \\
\hline Private Sector $1 /$ & 101 & 64 & 455 & -90 & 93 & 214 & 310 & 184 & -91 & 71 & 75 & 240 \\
\hline Direct investment & 22 & 32 & 91 & 110 & 128 & 125 & 124 & 64 & 48 & 53 & 70 & 236 \\
\hline Foreign currency deposits & 335 & 30 & 456 & -35 & 71 & 16 & 202 & 0 & 0 & 0 & 0 & 0 \\
\hline Other & -256 & 3 & -92 & -165 & -105 & 73 & -16 & 120 & -139 & 17 & 5 & 4 \\
\hline Errors and Omissions & -92 & 93 & -192 & 0 & 250 & 0 & 224 & 133 & 0 & 0 & 0 & 133 \\
\hline Overall Balance & 211 & 270 & 130 & 31 & 228 & 46 & 402 & 197 & 1 & 42 & 5 & 244 \\
\hline Net International Reserves (increase -) & -343 & -186 & -128 & -10 & -249 & -20 & -406 & -197 & -1 & -15 & -5 & -217 \\
\hline Gross Reserves & -342 & -185 & -129 & -10 & -249 & -20 & -406 & -197 & -1 & -15 & -5 & -217 \\
\hline Reserve Liabilities & -1 & -1 & 1 & 0 & 0 & 0 & 0 & 0 & 0 & 0 & 0 & 0 \\
\hline Exceptional Financing & 132 & -84 & -1 & -21 & 21 & -26 & 3 & 0 & 0 & -27 & 0 & -27 \\
\hline Arrears deferral (+)/clearance (-) & 91 & -84 & -1 & -21 & 21 & -26 & 3 & 0 & 0 & -27 & 0 & -27 \\
\hline Reschedulings & 0 & 0 & 0 & 0 & 0 & 0 & 0 & 0 & 0 & 0 & 0 & 0 \\
\hline \multicolumn{13}{|l|}{ Memorandum items: } \\
\hline Current account in percent of GDP & 2.3 & 2.0 & -0.4 & 2.1 & -1.2 & -2.2 & -1.5 & -3.3 & 2.6 & -0.9 & -3.6 & -1.3 \\
\hline Gross reserves (millions of U.S. dollars) & 983 & 1,168 & 1,297 & 1,307 & 1,546 & 1,317 & 1,703 & 1,899 & 1,900 & 1,915 & 1,920 & 1,920 \\
\hline in months of imports of GNFS & 3.5 & 3.4 & 2.5 & 3.5 & 2.6 & 3.6 & 3.0 & 3.2 & 3.2 & 3.2 & 3.2 & 3.2 \\
\hline External public debt in percent of GDP 2, & 48.1 & 41.3 & 34.6 & 30.4 & 26.3 & 31.5 & 25.4 & 0.0 & 0.0 & 0.0 & 0.0 & 23.4 \\
\hline Debt service in percent of exports GNFS & 11.6 & 7.5 & 8.9 & 8.7 & 6.2 & 8.6 & 6.0 & 0.0 & 0.0 & 0.0 & 0.0 & 5.8 \\
\hline Export Volume (percentage change) 3/ & 13.2 & 16.2 & 11.1 & $\ldots$ & $\ldots$ & 3.1 & 8.8 & $\ldots$ & $\ldots$ & $\ldots$ & $\ldots$ & 23.7 \\
\hline Import Volume (percentage change) $3 /$ & 8.7 & 17.1 & 13.0 & $\ldots$ & $\ldots$ & 5.0 & 47.9 & $\ldots$ & $\ldots$ & $\ldots$ & $\ldots$ & 8.2 \\
\hline Terms of trade (percentage change) & 1.5 & 0.0 & -15.6 & $\ldots$ & $\ldots$ & 4.3 & -8.4 & $\ldots$ & $\ldots$ & $\ldots$ & $\ldots$ & 4.8 \\
\hline
\end{tabular}

Sources: Central Bank of Paraguay; and Fund staff estimates.

$1 /$ Includes public enterprises and binationals.

2/ Based on end-of-period exchange rate conversion of U.S. dollar-denominated debt.

3/ Registered trade. 
Table 10. Paraguay: Indicators of External Vulnerability

\begin{tabular}{|c|c|c|c|c|c|}
\hline & 2002 & 2003 & 2004 & 2005 & 2006 \\
\hline \multicolumn{6}{|l|}{ Monetary and financial indicators } \\
\hline Broad money (M3), percentage change $1 /$ & -21.0 & 17.7 & 12.3 & 9.3 & 6.2 \\
\hline Credit to the private sector, real (percentage change) $1 /$ & -31.1 & -25.5 & 10.9 & 3.9 & -4.9 \\
\hline Share of nonperforming loans in total loans (percent) $2 /$ & 19.7 & 20.6 & 10.8 & 6.6 & 3.3 \\
\hline Average domestic lending rate, real $2 /$ & 39.0 & 19.3 & 17.4 & 18.6 & 15.4 \\
\hline Central Bank bill yield, real 2/ & 12.9 & -1.2 & 1.0 & -0.1 & 0.8 \\
\hline International reserves (millions of US\$) & 641 & 983 & 1,168 & 1,297 & 1,703 \\
\hline Central bank foreign short-term liabilities (millions of US\$) & 0.5 & 0.5 & 0.3 & 0.7 & 0.0 \\
\hline \multicolumn{6}{|l|}{ External indicators } \\
\hline Merchandise exports (percentage change) & -1.6 & 16.8 & 32.0 & 14.9 & 45.8 \\
\hline Merchandise imports (percentage change) & -14.6 & 14.4 & 27.0 & 22.5 & 50.4 \\
\hline Merchandise terms of trade (percentage change) & 3.0 & 1.5 & 0.0 & -15.6 & -8.4 \\
\hline Real effective exchange rate (percentage change) & 11.1 & -6.6 & 3.7 & -6.5 & 12.5 \\
\hline Current account balance (percent of GDP) & 1.8 & 2.3 & 2.0 & -0.4 & -1.5 \\
\hline Capital and financial account (percent of GDP) & 1.0 & 3.2 & 0.5 & 4.7 & 3.5 \\
\hline Net foreign direct investment (percent of GDP) & 0.2 & 0.4 & 0.5 & 1.2 & 1.3 \\
\hline Inward portfolio investment (percent of GDP) & 0.0 & 0.0 & 0.0 & 0.0 & 0.0 \\
\hline Other net investment (percent of GDP) & 0.7 & 2.6 & -0.1 & 3.2 & 1.0 \\
\hline External public debt (percent of GDP) 3/ & 63.6 & 48.1 & 41.3 & 34.6 & 25.2 \\
\hline Debt service (in percent of exports GNFS) & 9.1 & 11.6 & 7.5 & 8.9 & 6.0 \\
\hline Gross reserves (in US\$) & 641 & 983 & 1,168 & 1,297 & 1,703 \\
\hline In months of imports of GNFS & 2.8 & 3.5 & 3.4 & 2.5 & 3.0 \\
\hline Over short-term external debt 4 / & 1.0 & 1.6 & 1.7 & 1.9 & .. \\
\hline Over foreign currency deposits in domestic banks & 0.7 & 1.0 & 1.1 & 1.1 & .. \\
\hline
\end{tabular}

Sources: Central Bank of Paraguay; and Fund staff estimates.

1/ Foreign currency components are valued at the accounting exchange rate of Gs. 6,280 per U.S. dollar.

2/ Latest available data, September 2005.

3/ Based on end-of-period exchange rate conversion of U.S. dollar-denominated debt.

4/ Private and public external debt with a residual maturity of one year or less. Excludes foreign currency deposits in banking system. 


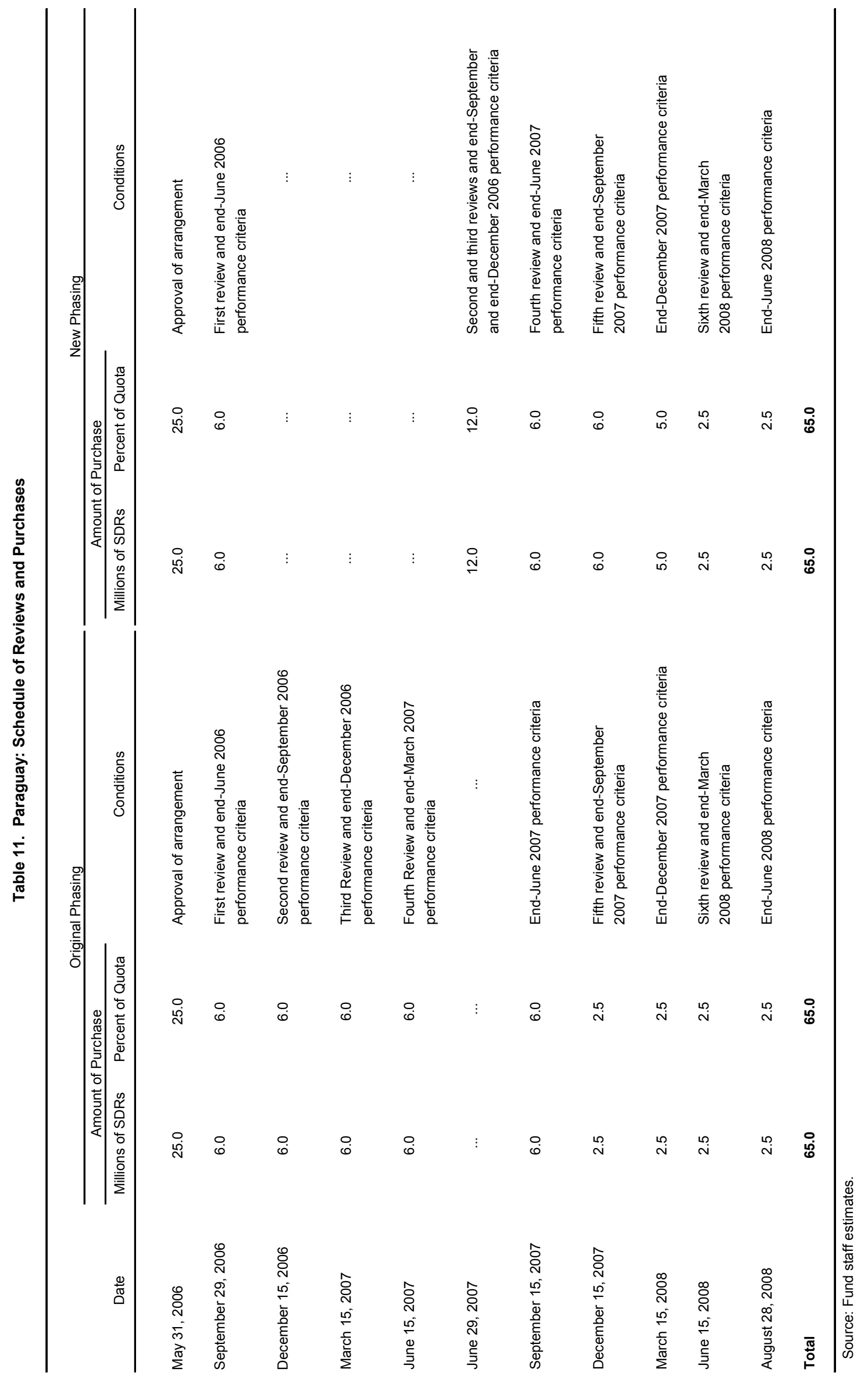


Table 12. Paraguay: Medium-Term Scenario

\begin{tabular}{|c|c|c|c|c|c|c|c|c|c|}
\hline & 2004 & 2005 & 2006 & 2007 & 2008 & 2009 & 2010 & 2011 & 2012 \\
\hline & & & Est. & \multicolumn{6}{|c|}{ Projections } \\
\hline \multicolumn{10}{|l|}{ Real sector } \\
\hline Real GDP growth (annual percentage change) & 4.1 & 2.9 & 4.0 & 4.0 & 4.5 & 4.5 & 5.0 & 5.0 & 5.0 \\
\hline Consumer prices (annual percentage change) & 2.8 & 9.9 & 12.5 & 5.0 & 3.0 & 3.0 & 3.0 & 3.0 & 3.0 \\
\hline GDP per capita (US dollars) & 1,220 & 1,289 & 1,562 & 1,856 & 1,863 & 1,926 & 2,002 & 2,086 & 2,182 \\
\hline & \multicolumn{9}{|c|}{ (In percent of GDP) } \\
\hline Gross domestic investment & 20.8 & 19.6 & 21.4 & 22.8 & 23.8 & 24.6 & 25.0 & 24.5 & 25.3 \\
\hline Private sector & 16.1 & 14.6 & 16.6 & 17.2 & 17.5 & 17.8 & 18.2 & 17.8 & 18.3 \\
\hline Public sector & 4.7 & 5.0 & 4.8 & 5.6 & 6.2 & 6.8 & 6.8 & 6.7 & 6.9 \\
\hline Gross national savings & 22.8 & 19.2 & 19.9 & 21.5 & 22.3 & 23.1 & 23.4 & 22.9 & 23.6 \\
\hline Private sector & 16.3 & 13.4 & 14.8 & 15.9 & 16.1 & 16.3 & 16.6 & 16.2 & 16.7 \\
\hline Public sector & 6.5 & 5.8 & 5.1 & 5.6 & 6.2 & 6.7 & 6.8 & 6.6 & 6.9 \\
\hline \multicolumn{10}{|l|}{ Public finances $1 /$} \\
\hline Revenues & 21.6 & 21.9 & 22.2 & 22.1 & 22.3 & 22.4 & 22.4 & 22.5 & 22.5 \\
\hline Current primary expenditures & 15.1 & 15.5 & 15.8 & 15.7 & 15.6 & 15.5 & 15.4 & 15.4 & 15.8 \\
\hline Interest payments & 1.6 & 1.6 & 1.6 & 1.9 & 1.7 & 1.5 & 1.5 & 1.3 & 1.2 \\
\hline Capital expenditures & 4.7 & 5.0 & 4.8 & 5.6 & 6.2 & 6.8 & 6.8 & 6.7 & 6.9 \\
\hline Public enterprise operating surplus & 1.4 & 1.4 & 1.4 & 1.2 & 1.2 & 1.4 & 1.2 & 0.8 & 1.5 \\
\hline Primary balance & 3.2 & 2.8 & 3.1 & 1.9 & 1.7 & 1.5 & 1.4 & 1.3 & 1.2 \\
\hline Overall balance & 1.8 & 0.9 & 0.4 & 0.0 & 0.0 & 0.0 & 0.0 & 0.0 & 0.0 \\
\hline Public sector debt $2 / 3 /$ & 45.1 & 37.7 & 27.5 & 25.4 & 24.0 & 23.6 & 23.1 & 22.5 & 21.9 \\
\hline Consolidated public sector debt $3 /$ & 49.2 & 43.0 & 34.1 & 32.9 & 31.4 & 29.6 & 27.8 & 25.9 & 24.0 \\
\hline & \multicolumn{9}{|c|}{ (In millions of U.S. dollars) } \\
\hline Public sector debt 2/ & 3,027 & 2,876 & 2,786 & 2,753 & 2,748 & 2,849 & 2,963 & 3,068 & 3,178 \\
\hline \multicolumn{10}{|l|}{ Balance of payments } \\
\hline Exports & 2,854 & 3,280 & 4,781 & 5,414 & 5,750 & 6,105 & 6,500 & 6,925 & 7,364 \\
\hline Imports & 3,102 & 3,800 & 5,715 & 6,300 & 6,658 & 7,043 & 7,473 & 7,929 & 8,415 \\
\hline Current account & 139 & -26 & -141 & -146 & -168 & -189 & -216 & -226 & -247 \\
\hline (In percent of GDP) & 2.0 & -0.4 & -1.5 & -1.3 & -1.5 & -1.6 & -1.7 & -1.7 & -1.7 \\
\hline Capital and financial account & 38 & 348 & 320 & 257 & 224 & 250 & 286 & 302 & 326 \\
\hline Gross international reserves & 1,168 & 1,297 & 1,703 & 1,920 & 1,977 & 2,037 & 2,107 & 2,183 & 2,265 \\
\hline (In months of imports) & 3.4 & 2.5 & 3.0 & 3.2 & 3.1 & 3.0 & 3.1 & 3.0 & 2.9 \\
\hline
\end{tabular}

Sources: Ministry of Finance; Central Bank of Paraguay; and Fund staff estimates and projections.

1/ Defined as the nonfinancial public sector and the BCP.

2/ Nonfinancial public sector debt; excludes Central Bank bills.

3/ Based on end-of-period exchange rate conversion of U.S. dollar-denominated debt. 


\section{Appendix 1. Paraguay-Letter of Intent)}

Asunción, Paraguay

June 15, 2007

Mr. Rodrigo de Rato

Managing Director

International Monetary Fund

Washington, D.C. 20431

Dear Mr. de Rato:

1. This letter and the attached memorandum of economic and financial policies (MEFP) update and supplement our letters of May 8, and September 12, 2006; describe performance under our economic program for 2006 and early 2007; and propose our economic program for the rest of 2007. The attached MEFP articulates, in some detail, the economic policies that the government intends to carry out during 2007 as well as the key targets of the program. The government's objectives continue to be the consolidation of our stabilization efforts while establishing policies to foster private investment, enhance employment, remove impediments to growth and reduce poverty on a sustainable basis.

2. Performance under our economic program, supported by a 27-month Stand-By Arrangement (SBA), has been quite strong. All quantitative and structural performance criteria through end-March 2007 were observed. With three exceptions (explained by the changes at the Central Bank leadership), all structural benchmarks were also met. Economic growth remains strong and inflation under control. The public finances are on a strong footing and international reserves are at a record high level.

3. To continue supporting our efforts, the Government of Paraguay hereby requests: (i) complete the second and third reviews under the SBA supported program; (ii) reschedule the missed structural benchmarks on designing the strategy to strengthen the financial position of the Central Bank to end-June 2007; (iii) modify the missed structural benchmark on implementing regulatory measures outlined in the banking strategy and sending to Congress amendments to the banking law to three new structural benchmark on: (a) the design of an ambitious action plan to strengthen financial sector reform and aiming at increasing the coverage of Basel Core Principles of banking supervision to around 80 percent by end-June 2007; (b) approval of a modified resolution 8/03 by end-September 2007 with a view to become effective on January 1, 2008; and (c) implementation of prudential regulations in line with the Central Bank's operational plan by end-December 2007; 
(iv) introduce an adjustor to the target on the Central Government balance for the cost of strengthening the financial position of the Central Bank; (v) move the fourth and fifth program reviews to mid-September and mid-December 2007 respectively, and switch to semi-annual program reviews (while retaining quarterly performance criteria) after the fifth SBA review; and (vi) rephase purchases according to the changes in reviews described before. We intend to continue treating the arrangement as precautionary.

4. The government of Paraguay will maintain the continuous and fruitful dialogue with the Fund, the government believes that the policies set forth in the attached MEFP are adequate to achieve the objectives of its program, but we will take any further measures that may become appropriate for this purpose. In the spirit of cooperation, Paraguay will consult with the Fund on the adoption of these measures, in accordance with the Fund's policies on such consultation. We will also provide Fund staff with all the relevant information required to complete program reviews and monitor performance.

5. As part of our information policy, we intend to publish this letter and the attached MEFP on the websites of the Ministry of Finance and Central Bank to keep the public informed. We also authorize the Fund to publish these documents to facilitate a wider dissemination of our policies among the international community.

Sincerely yours,
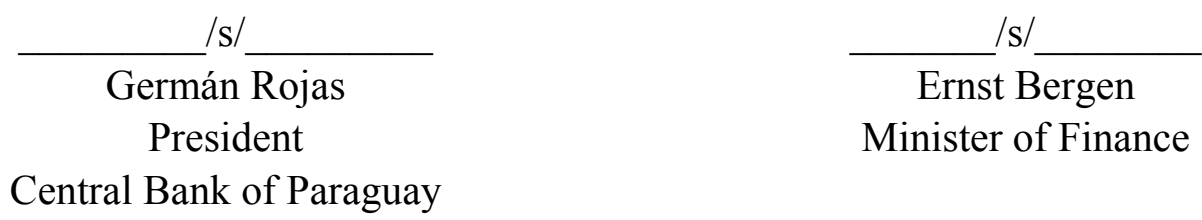

Central Bank of Paraguay 


\section{Appendix 2. Memorandum of Economic and Financial Policies of the Government of Paraguay (MEFP)}

\section{BACKGROUND}

\section{Following the successful stabilization of the period 2003-05, the government} adopted an ambitious economic program for 2006-08 to promote growth and reduce poverty while entrenching macroeconomic stability. Right after taking office, the administration of President Duarte-Frutos designed a program to stabilize the economy, address deep-rooted macroeconomic imbalances and lessen remaining regional contagion. The program was supported by a Stand-By Arrangement from the IMF and quickly began to bear fruit. During the stabilization period of 2003-05 we achieved some of the best macroeconomic results in a decade. The economy began to grow; the public finances were adjusted in an orderly manner; the financial system was strengthened; and the Central Bank tightened its control on inflation while managing to increase international reserves to record highs. These stabilizing efforts were underscored by the successful completion of the SBA in November 2005. Subsequently, we embarked upon designing a program for the period 2006-08 with the objective of removing impediments to growth, and alleviating poverty, while cementing economic stability. The program contains an ambitious structural reform agenda and a strong macroeconomic component. The medium-term objectives of the program are to keep the growth rate of the economy to 4-5 percent; to tend to reduce inflation to industrial country levels; keep the consolidated public debt burden below 30 percent of GDP; and maintain a comfortable international reserve position.

\section{The program remains on track as policy implementation was strengthened.}

Performance under the program has been quite strong. Following strict adherence to all targets for end-June 2006, all quantitative performance criteria for end-September and endDecember 2006 were observed. ${ }^{1}$ On the structural front, the two structural performance criteria and all but three benchmarks were observed through end-April 2007. ${ }^{2}$ With the aim

\footnotetext{
${ }^{1}$ The variables subject to quarterly quantitative performance criteria under the program include: (i) overall balance of the Central Administration; (ii) wage bill of the Central Administration; (iii) overall balance of the consolidated public sector; (iv) net international reserves of the Central Bank; (v) net domestic assets of the Central Bank; (vi) contracting or guaranteeing of nonconcessional external debt by the nonfinancial public sector; (vii) contracting or guaranteeing of short-term external debt by the nonfinancial public sector on a continuous basis; and (viii) non-accumulation of external debt arrears on a continuous basis.

${ }^{2}$ The list of structural measures observed through April 2007 include: (i) improve the capital-risk-weightedasset ratio of the National Development Bank (BNF) to 5 percent by end-June 2006 and 10 percent by endDecember 2006 according to an audited and inspected balance sheet (performance criterion); (ii) design a plan to improve the business climate by end-September 2006; (iii) preparation of the tax code by end December 2006 (performance criterion); (iv) implement result-oriented management contracts for ANDE, COPACO, ESSAP, INC and PETROPAR by end-December 2006; (v) creation of a conditional cash transfer system for 7,000 families living under conditions of extreme poverty based on contracts with beneficiaries by endDecember 2006. The missing benchmarks were: (i) implementation of the regulatory measures outlined in the
} 
areas: (i) public sector reform; (ii) financial sector reform; (iii) pro-growth agenda; and (iv) a social safety net to alleviate poverty. Performance criteria and structural benchmarks for 2007 related to these policies are specified in Tables 1 and 2 and further defined in the attached technical memorandum of understanding. Policies for 2008 will be articulated at the time of the fifth program review, expected for late 2007.

\section{MaCroeconomic Program for 2007}

6. The macroeconomic framework for the 2007 program aims at raising growth and reducing inflation. An important program objective will be to raise economic growth to the 4-5 percent range in 2007. This objective seems realistic as agriculture is expected to rebound and the supply effects of the structural reforms begin to have an impact on the economy. Another key objective for the 2007 program is to tend to reduce the core inflation rate to 5 percent (within a range of $+/-2 \frac{1}{2}$ percent), as the impact of supply shocks is absorbed, and the Central Bank continues with an adequate control of monetary aggregates.

\section{A. Fiscal Policy}

7. The program aims at maintaining fiscal discipline while targeting higher capital spending. The 2007 budget submitted to Congress envisaged a small deficit of 0.8 percent of GDP. Given financing constraints and the objective to reduce the debt-to-GDP ratio, we have designed a financial plan to limit spending and achieve a balanced fiscal position. The program's objective is to contain non-social current expenditures of the Central Administration while allowing for a higher level of capital and social expenditure to support growth and poverty alleviation efforts. In particular, the program aims at increasing capital 1 expenditure to $4 \frac{1}{2}$ percent of GDP and to further increase social spending.

8. An adjustor will be introduced to facilitate the implementation of the structural reform agenda. The fiscal targets will be adjusted to accommodate the cost of structural reforms. In particular, the fiscal target for the Central Administration will be adjusted to take into account the interest cost or additional transfers resulting from the government's intention to strengthen the financial position of the Central Bank. In the case of issuance of bonds, the interest costs will be recorded as part of the expenditure of the Central Administration. This adjustor will apply to the Central Administration, but not to the Consolidated Public Sector.

9. As in the past, the program will endorse higher than targeted levels of public investment and poverty alleviation programs, provided appropriate safeguards are in place. The 2007 program will allow for a level of capital and targeted social expenditures beyond program objectives provided that macroeconomic conditions allow the absorption of these expenditures and there is revenue over-performance or else financing on appropriate terms directed to high quality projects. This issue will be addressed in the context of program reviews. 
of strengthening program implementation, the Government issued decree 7712 in June 2006 by which the execution of specific measures under the program is delegated to individual Ministries within the Government. The same decree also provides adequate control and monitoring mechanisms to ensure a successful program implementation.

3. Economic conditions continued to improve in 2006. Real GDP is estimated to have grown by 4 percent, exceeding the program objective of $3 \frac{1}{2}$ percent for 2006 , driven by a combination of a strong external demand (buoyant exports, especially for beef) and a dynamic domestic demand (higher private investment, especially in mobile telecommunications). Headline inflation exceeded the program objective of 7 percent for 2006, mostly on account of a surge in beef prices in the regional and international markets; however core inflation (excluding the beef price shock) was in line with the program objective. The public finances remained with a small surplus in 2006, against a program objective of fiscal balance, mainly due to strong tax collections and strict control on expenditures. The Central Bank managed to accumulate a record level of reserves in 2006, while maintaining control of monetary aggregates and allowing the guarani to strengthen against major international currencies, as the external position continued to be positive.

\section{Economic performance in the first quarter of 2007 was also strong, and} macroeconomic stability was further enhanced. Following the unwinding of the supply shock observed at end-2006, the price level fell by $1 \frac{1}{2}$ percent, bringing down the 12 -month rate of headline inflation to about 6 percent by end-April. We have maintained strong fiscal discipline, and the central government budget recorded a significant surplus in the first quarter on account of continued strong revenue performance and expenditure restraint. The export sector enjoyed robust growth as a result of continued productivity increases, especially in soy and beef production, as well as from favorable external conditions. As a result, we strengthened our reserve position by over US\$300 million in the first four months of 2007 to reach yet another historic record. In view of the positive external position, large level of reserves, progress in implementing the program, and in recognition of the revolving nature of the Fund resources, we request - in the context of the next program review-a reduction in access under the Stand-By Arrangement (which would also reduce the commitment fee).

5. The program for 2007 envisages further consolidation of the stabilization gains and further deepening of the reform agenda to achieve higher growth. The structure of the 2007 program will be similar to that of 2006. The program will continue to be based on five policy pillars, a strong macroeconomic program anchored by fours structural reform

Central Bank's banking strategy and the amendments to the banking law according to the same strategy by endSeptember 2006; (ii) design of a strategy to strengthen the financial position of the Central Bank by endDecember 2006; and (iii) send to Congress a bill with the legal and budgetary implication of the abovementioned strategy by mid-April 2007. 
10. The program seeks to achieve fiscal balance at the consolidated public sector level. The rest of the public sector is expected to maintain its surplus position by restraining current expenditures. This will help in covering the expected losses of the Central Bank or the Central Administration once the Central Bank's position is being strengthened.

\section{B. Monetary Policy}

11. The key monetary policy objective of the 2007 program will be to maintain core inflation at around 5 percent. While this may appear as an ambitious target given the end2006 headline inflation of $12 \frac{1}{2}$ percent, the core inflation was about 7 percent at the end of the same period. Moreover, with a deflation of about $1 \frac{1}{2}$ percent in the first four months, the 12-month rate of inflation already fell to about 6 percent in April 2007. However, given the variability of inflation and the vulnerability to external shocks, the Central Bank believes it is prudent to adopt a range of plus/minus two and a half percentage points, making the core inflation range $2 \frac{1}{2}$ to $7 \frac{1}{2}$ percent in 2007 .

12. To achieve the inflation objective, the Central Bank will maintain to reasonable levels the growth of monetary aggregates. The Central Bank will follow a monetary policy that is consistent with an economy growing at 4-5 percent, a core inflation objective of 5 percent (within a range of $+/-2 \frac{1}{2}$ percent), and a moderate strengthening in real money demand. The Central Bank made large purchases of foreign exchange in the first quarter of 2007 to prevent the exchange rate from appreciating beyond fundamentals and reduced interest rates to stop attracting foreign exchange inflows. For the rest of the year, the Central Bank will focus its policy on controlling the pace of currency expansion through additional placements of "Letras de Regulación Monetaria." With a record level of international reserves beyond US\$2 billion at end-May 2007, the Central Bank does not have a need to accumulate further reserves and might use part of the foreign exchange purchased earlier in the year in case there is a reversal of the flows. In any case, the Central Bank level of international reserves will not be below US\$1.92 billion by end-2007.

\section{STRUCTURAL REFORMS FOR 2007}

13. The structural reform agenda for $\mathbf{2 0 0 7}$ will continue to build on the accomplishments of the past year with the ultimate objective of removing impediments to growth. Plans designed in 2006 will be implemented in 2007. Measures already agreed for 2007 will be executed during the year. Reforms that began last year will be finalized in 2007/08. In designing the reform agenda, we have minimized the use of legislative change. However, in those cases where it has been impossible to make progress without some form of legislative action, we will work closely with the National Congress to initiate the dialogue and explain the rationale for the proposed legislation, increasing ownership of the reform process and facilitating the approval of the proposed legislation. 


\section{A. Public Sector Reform}

14. The institutional framework for tax collection will continue to be strengthened. The increases in tax collections of the last few years need to be locked in through the adoption of a tax procedures code to ensure macroeconomic stability over the medium-term. Following the design of a draft tax procedures code in December 2006, the Ministry of Finance will prepare the implementing regulations for such tax procedures code by endSeptember 2007 (structural benchmark). We will continue requesting technical assistance from the IMF for this purpose.

15. A coherent public expenditure policy will be designed to improve the efficiency of government spending. The current system is quite rigid and lacks adequate control systems. Reforms are needed to ensure that expenditures are carried out in the areas with higher social return.

- $\quad$ Controls on current expenditures will be firmed up to better achieve agreed limits and avoid undue fluctuations in spending patterns. Following the design of an action plan to develop effective commitment control systems for the public sector in June 2006, the Ministry of Finance will establish an expenditure control system at the commitment level for the Executive Branch by end-December 2007 (structural benchmark). This will require regulations and changes in the financial management information system needed to record all budget execution stages. We will continue requesting technical assistance from the IMF for this purpose.

- Selection of investment projects will be strengthened to increase the efficiency of capital expenditures. Given the shortfalls in project implementation and the lack of a comprehensive system to establish priorities in public investment over the mediumterm, the Ministry of Finance will design a public sector investment system to improve prioritization, efficiency, maximize investment return, and ensure that programs reflect the government priorities by end-December 2007 (structural benchmark). We will request technical assistance from the Inter-American Development Bank for this purpose.

- A comprehensive approach is needed to solve the common problems of the different pension systems. This will complement the piecemeal approach adopted in the past to solve the financial problems of specific pension systems. To this end, the Ministry of Finance will develop an action plan for a pension reform aimed at ensuring its longterm solvency, appropriately endorsed by the Economic Cabinet by end-September 2007 (structural benchmark).

\section{B. Financial Sector Reform}

16. Reforms are needed in a number of areas to enhance the functioning of the

financial system. Significant progress has been made in strengthening the architecture of the 
domestic financial system since the emergence of the 2002 financial crisis (including by upgrading the banking resolution framework, introducing deposit insurance, and improving the financial situation of BNF) but additional steps are needed to consolidate those gains.

- $\quad$ The supervisory and regulatory framework for banks needs to be strengthened. The Central Bank will continue in their efforts to strengthen the financial system and will take the following measures:

\section{The Central Bank will design an ambitious plan and timetable to reshape the} banking sector reform. The plan will address weaknesses in the regulatory and supervisory frameworks of the banking system and will be finalized by end-June 2007 (structural benchmark). The plan will aim at increasing compliance with the Basel Core Principles of Banking Supervision to the highest in the region (about 80 percent). We will continue requesting technical assistance from the IMF for this purpose.

$>$ A modified resolution $8 / 03$ will be reinstated. The Central Bank will enter in a process of consultation with the banking community with a view to reach consensus on a modified resolution $8 / 03$ to upgrade credit requirements, loan classification and provisioning. The Central Bank Board will approve a modified resolution $8 / 03$ by end-September 2007 (structural benchmark), which will become effective on January 1, 2008.

$>$ Prudential regulations will be bolstered. The Central Bank Board will implement a number of prudential regulations included in the Central Bank's operational plan (approved in November 2005) with the aim of strengthening criteria for calculating capital requirements, improving rules for provisioning, streamlining administrative sanctions proceedings, rationalizing rules on open net foreign exchange positions and the public reporting on banks' financial position by endDecember 2007 (structural benchmark). We will continue requesting technical assistance from the IMF for this purpose.

- $\quad$ A regulatory framework for cooperatives will be designed. To reduce regulatory and supervisory differences between financial institutions, and reduce vulnerabilities to the financial system, INCOOP will develop an effective supervisory and regulatory framework for financial cooperatives by end-September 2007 (structural benchmark). These efforts will aim at leveling the regulatory and supervisory playing field for financial institutions in the country. INCOOP will also strengthen the monitoring framework to compile monetary statistics for the main cooperatives, and their incorporation in the Central Bank's monetary statistics.

- Measures will be taken to improve the payment system. As part of the modernization efforts of the financial system to enhance liquidity management, facilitate 
transactions and mobilize financial resources as well as improving the conduct of monetary policy, the Central Bank will implement the regulatory framework addressing weaknesses in the payment system, and in consultation with the government, will prepare a draft payments system law approved by the economic cabinet by end-September 2007 (structural benchmark). We aim at establishing a realtime gross settlements system (RTGS) by 2008. We will request technical assistance from the IMF for this purpose.

17. While significant progress has been made in strengthening the National Development Bank, further efforts are needed to reduce the vulnerability of the system. The program includes two main objectives on BNF

- $\quad$ Further strengthening the bank's financial position is still needed. A milestone of the program has been to turn around BNF's capital from negative (technically bankrupt) to positive through improvements in its administration, which allowed for profit increases and bad debt recoveries. The independent audit confirmed that our objective to increase BNF's capital adequacy ratio to 10 percent by December 2006 was achieved. We will continue strengthening BNF's management to ensure that the bank remains viable over the medium-term.

- $\quad$ Additional efforts will be required to restructure the bank. To consolidate BNF's financial position, and strengthen its lending policies, BNF will develop a strategy for reducing its operating costs, increasing its asset recovery, improving its credit and risk management practices, and enhancing its internal controls by end-June 2007 (structural benchmark).

18. It is imperative to continue with the efforts to strengthen the financial position of the Central Bank to enhance the effectiveness of monetary policy. We intend to announce a strategy to strengthen the Central Bank's balance sheet and a timetable for its implementation by June 2007 (structural benchmark), the Ministry of Finance will prepare and send legislation to Congress that reflects the budgetary implications of such strategy by September 2007 (structural benchmark). We will continue requesting technical advice from the IMF for this purpose.

19. The development of capital markets will be necessary to foster domestic savings and improve its allocation into productive investment projects. Capital markets are at an early stage of development and serious efforts are needed for these markets to emerge. It will require a number of legal changes as well as institutional development. The Ministry of Finance, in coordination with the Central Bank, will design a strategy for the development of capital markets by end-December 2007 (structural benchmark). The strategy will identify all public obligations; aim to convert all non-marketable public obligations into marketable securities; formulate a plan for improving the profile of domestic public debt; and revamp the 
legal framework for government debt management and the development of the government securities market. We will request technical assistance from the IMF for this purpose.

\section{Pro-Growth Agenda}

20. Higher levels of foreign and domestic investment will require improvements in the investment climate in the country. A better investment climate will lead to higher investment and higher growth. Following the design of a master plan to help promote the investment climate in September 2006, the Ministry of Industry will implement such plan by end-September 2007 (structural benchmark).

21. Improvements in the efficiency of public enterprises are necessary to provide better public services and increase productivity economy-wide. Public enterprises cover a wide range of economic activities and improvements in their performance are necessary for the proper functioning of the economy. Following the design of result-oriented management contracts for ANDE, COPACO, ESSAP, INC, and PETROPAR in December 2006, the Public Enterprise Supervising Council will publish the assessment reports according to the schedules defined in the contracts. It will also ensure that these performance contracts are satisfactorily observed during the year with an assessment by end-December 2007 (structural benchmark).

\section{Social Safety Net}

22. While the conditional cash transfer program was implemented, its coverage needs to be broadened to become an effective vehicle for poverty alleviation. Following the successful introduction of this program to some 8,800 families living under extreme poverty in 2006 (well above the program objective of 7,000 families, the challenge for 2007 is to strengthen the monitoring mechanisms and the required provision of health and education services while at the same time increasing the number of families receiving these transfers. Notwithstanding these logistic and budgetary challenges, the Ministry of Social Action will aim at widening the coverage of this program to 15,000 families by endDecember 2007 (structural benchmark). We will request technical assistance from the IDB for this purpose.

\section{OTHER}

We will continue to seek resolution to the disputed claims, negotiating in good faith. There are a number of existing claims in dispute, which we hope to resolve during the program. We will do the same for any new disputed claims that may arise. 
Table 1. Paraguay: Quantitative Program Targets

2007

End-Jun End-Sep End-Dec

\section{Fiscal targets}

1. Overall balance of the central administration (floor, in billions of guaranies) $1 / 2 /$

184

2,055

202

3. Overall balance of the public sector (floor, in billions of guaranies) $1 /$

Monetary targets

4. Net international reserves (floor, in millions of U.S. dollars) 3/

5. Net domestic assets (ceiling, in billions of guaranies) 3/

Public debt and arrears targets

6. Contracting or guaranteeing of nonconcessional external debt by the NFPS

(ceiling, in millions of US\$) $1 /$

Continuous PCs

7. Contracted or guaranteed short-term external debt by the NFPS

8. Non-accumulation of external debt arrears
1,900

1,915

1,920

$-6,645$

$-6,700$

$-6,016$

1/ Cumulative flows from the beginning of the calendar year.

2/ For 2007 adjusted downward for any cash transfer or payment of interest costs on securities used to strengthen the financial position of the central banl 3/ NIR stock is adjusted upward (downward) for any increase (decrease) in reserve requirement for foreign currency

deposits (above pre-specified amounts) and upward by the amount of any program disbursements. Similarly, the NDA target will be adjusted downward (upward) following the adjustment in the NIR. 
Table 2. Paraguay: Proposed Structural Conditionality Under the Program for 2007

Measure

Conditionality $^{1 /}$

Timing

Public Sector Reform

A. Draft implementing regulations for the tax procedures code

end-Sep 2007

B. Develop an action plan for a comprehensive pension reform

SB

end-Sep 2007

C. Design a public sector investment system

SB

end-Dec 2007

D. Establish a commitment control system

SB

end-Dec 2007

Financial Sector Reform

E. Announce a strategy to strengthen the financial position of

end-Jun 2007 the Central Bank and the timetable for its implementation

F. Develop a medium-term business plan for BNF that includes a strategy to reduce costs, increase asset recovery, and improve credit and risk management

G. Develop legal and regulatory framework to revamp the payment system and preparing a draft payment system law

H. Design an action plan to strengthen financial sector reform and increase compliance with Basel Core Principles to at least 80 percent (in line with regional best practices)

I. Send a bill to Congress that reflects the legal and budgetary implications of the agreed plan to strengthen the financial position of the Central Bank

J. Design a strategy for the development of capital markets

K. Development of an effective supervisory and regulatory framework for the cooperative sector

L. Reinstate a modified Resolution 8/03 to become effective on January 12008

M. Implement prudential regulations in line with BCP operational plan

\section{Pro-Growth Reform}

N. Implement the plan to improve the investment climate designed in September 2006.

O. Observance of targets under the result-oriented management contracts for ANDE, COPACO, ESSAP, INC, and PETROPAR

\section{Social Safety Net}

P. Increase the coverage of the conditional cash transfer program to 15,000 families and establish mechanisms for the evaluation of results.

$1 / \mathrm{SB}=$ structural benchmarks. 


\section{Appendix 3. Paraguay-Technical Memorandum of Understanding}

This Technical Memorandum of Understanding (TMU) defines the variables subject to quantitative targets (performance criteria and indicative targets), specified in the Memorandum of Economic and Financial Policies (MEFP). It also describes the methods to be used in assessing the program performance and the information requirements to ensure adequate monitoring of the targets.

\section{A. Fiscal Targets}

\section{Targets on the Overall Balance of the Central Administration}

\begin{tabular}{lc}
\hline Cumulative balance from December 31, 2006 & $\begin{array}{c}\text { Floor } \\
\text { (In billions of } \\
\text { guaraníes) }\end{array}$ \\
\hline End-June 2007 (performance criterion) & 184 \\
End-July 2007 (program projection) & \\
End-August 2007 (program projection) & 251 \\
End-September 2007 (performance criterion ) & 278 \\
End-October 2007 (program projection) & 330 \\
End-November 2007 (program projection) & 335 \\
End-December 2007 (performance criterion) & 351 \\
\hline
\end{tabular}

For the purposes of the program, the central administration (CA) includes the executive, judicial and legislative branches. The overall balance of the CA will be measured and monitored from the financing side, as equal to minus the net financing of the CA. The net financing of the CA is defined as the sum of: (i) net external financing to the central government; (ii) the change in net credit to the central government from the financial system, excluding government bonds; (iii) the net issuance of government bonds; (iv) net financing from all other sources to the government (consisting of any form of financing other than government bonds) including by the private sector; (v) asset sales; (vi) the net change in domestic floating debt (deuda flotante), as defined below; and (vii) the net change in external arrears. Items denominated in foreign currency will be converted into guaranies at the average exchange rate for each month.

For the purposes of the program, any government bonds issued to (i) capitalize the central bank, (ii) capitalize the Banco Nacional de Fomento (BNF), or (iii) finance the deposit guarantee will not be included in the definition of fiscal deficit.

Net external financing is defined as central government's foreign borrowing, including bonds issued abroad, less amortization payments (including debt prepayments) of foreign debt. Net 
credit from the financial system is defined as the change in net credit to government, as reported in the monetary accounts of the $\mathrm{BCP}$, excluding government bonds. Net change in domestic floating debt is defined as the difference between accrued expenditure (gastos obligados) and payments transferred (gastos transferidos). Net change in external arrears is defined as the difference in the stock of arrears to external creditors during a period of reference, as reported by the ministry of finance's SIGADE system. Data will be provided to the Fund by the ministry of finance with a lag of not more than three weeks past the test date.

The floor on the Cumulative Central Administration Overall Balance for 2007 will be adjusted downward by the full amount of cumulative transfers and/or interest due on any bonds issued during 2007 as part of the program to strengthen the financial position of the Central Bank.

\section{Targets on the Central Administration Wage Bill}

\begin{tabular}{lc}
\hline Cumulative flows from December 31, 2006 & $\begin{array}{c}\text { Ceiling } \\
\text { (In billions of guaranies) }\end{array}$ \\
\hline End-June 2007 (performance criterion) & 2,055 \\
End-July 2007 (program projection) & 2,393 \\
End-August 2007 (program projection) & 2,736 \\
End-September 2007 (performance criterion ) & 3,086 \\
End-October 2007 (program projection) & \\
End-November 2007 (program projection) & 3,434 \\
End-December 2007 (performance criterion) & 3,789 \\
\hline
\end{tabular}

The wage bill of the $\mathrm{CA}$ is defined as the accrued remuneration to all central administration employees (servicios personales), including overtime and effective social contributions (budget line items 100-199), ${ }^{1}$ as reported in by the ministry of finance's monthly Situación Financiera de la Administración Central. Data will be provided to the Fund by the ministry of finance with a lag of not more than three weeks past the test date.

1 It will exclude any Treasury transfers to the Caja Fiscal registered as wages for new employment positions authorized in the budget but not yet appointed. 


\section{Targets on the Overall Balance of the Consolidated Public Sector}

\begin{tabular}{lc}
\hline Cumulative flows from December 31, 2006 & $\begin{array}{c}\text { Floor } \\
\text { (In billions of guaraníes) }\end{array}$ \\
\hline End-June 2007 (performance criterion) & 202 \\
End-July 2007 (program projection) & 336 \\
End-August 2007 (program projection) & 429 \\
End-September 2007 (performance criterion ) & 459 \\
End-October 2007 (program projection) & 449 \\
End-November 2007 (program projection) & 397 \\
End-December 2007 (performance criterion) & 0 \\
\hline
\end{tabular}

For the purposes of the program, the consolidated public sector comprises: (i) the nonfinancial public sector (NFPS) and (ii) the Central Bank of Paraguay (BCP).

The NFPS includes the CA as defined above, the social security institutes, the provincial governments, autonomous decentralized agencies, and the nonfinancial public enterprises. ${ }^{2}$

Under the program, the consolidated public sector's overall balance will be measured and monitored as equal to minus the net financing of the NFPS, plus the operating balance of the BCP. The net financing of the NFPS is defined as the sum of: (i) net external financing; (ii) the change in net domestic credit to public sector from the financial system, excluding government bonds; (iii) the net issuance of government bonds; and (v) other net financing of the nonfinancial public sector by the private sector, including net increase in the stock of domestic floating debt, external arrears, and asset sales. Items denominated in foreign currency will be converted into guaranies at the average exchange rate for each month.

Net external financing of the NFPS is defined as all external disbursements less amortization paid by the NFPS as defined above. The change in net credit is defined as the net flow of gross domestic credit (excluding treasury bonds) plus use of deposits by the NFPS in the domestic financial system. Domestic floating debt of the NFPS is defined as the difference between accrued expenditure (gastos obligados) and payments transferred (gastos transferidos) vis-à-vis the private sector. It will be measured as the central government

\footnotetext{
${ }^{2}$ Altogether they include: Pension funds (Instituto de Previsión Social (IPS), Caja Bancaria, Caja Ande, Caja Ferroviaria, Caja de Empleados Municipales), the public universities (UNA, UNE, UNP, UNI), 17 provinces (gobiernos departamentales), 17 autonomous regulatory and development agencies, the public enterprises (PETROPAR, ANDE, ANNP, DINAC, and INC) and incorporated enterprises owned by the state (ESSAP and COPACO).
} 
floating debt net of debts with the rest of the NFPS as defined herein. External arrears are defined as the sun of (i) any principal and interest accrued by the NFPS and not paid by the due date as reported by the ministry of finance's SIGADE; (ii) the net change in arrears to foreign suppliers of the NFPS. The operating balance of the BCP is measured as all administrative and financial revenues minus costs (including costs of monetary policy and interest on BCP external debt). Data will be provided to the Fund by the ministry of finance and the central bank with a lag of not more than three weeks past the test date.

\section{B. Monetary Targets}

\section{Targets on Net International Reserves of the Central Bank of Paraguay (BCP)}

\begin{tabular}{lc}
\hline & $\begin{array}{c}\text { Floor } \\
\text { Outstanding stock as of: }\end{array}$ \\
\hline End-December 2006 & 1,703 \\
End-June 2007 (performance criterion) & 1,900 \\
End-July 2007 (program projection) & 1,905 \\
End-August 2007 (program projection) & 1,910 \\
End-September 2007 (performance criterion) & 1,915 \\
End-October 2007 (program projection) & 1,920 \\
End-November 2007 (program projection) & 1,925 \\
End-December 2007 (performance criterion) & 1,920 \\
\hline
\end{tabular}

For monitoring purposes, net international reserves (NIR) of the BCP are defined as the U.S. dollar value of gross foreign assets in foreign currencies minus gross liabilities in foreign currencies with original maturity of less than one year. Data will be provided by the BCP to the Fund with a lag of not more than five days past the test date.

Gross foreign assets are defined consistent with SDDS and include all liquid foreign currency-denominated claims of BCP, including monetary gold, holdings of SDRs, the reserve position in the IMF, and foreign currency in the form of cash, deposits abroad, and Paraguay's net cash balance within the Latin America Trade Clearing System (ALADI). Excluded from gross foreign assets are participations in international financial institutions (including Corporación Andina de Fomento (CAF), IDB, IBRD, Asociación Internacional de Fomento, and Banco de Desarrollo del Caribe), the holdings of nonconvertible currencies, and holdings of precious metals other than gold. Gross foreign liabilities are all foreign currency denominated BCP liabilities of contracted maturity up to and including one year plus the use of Fund credit. Non-U.S. dollar denominated foreign assets and liabilities will be converted into U.S. dollars at the market exchange rates of the respective currencies as of December 31, 2006. 
NIR targets will be adjusted upward (downward) for any increase (decrease) in reserve requirement deposits (encaje) associated with foreign currency deposits in commercial banks, compared to the following levels: June 30, 2007: US\$292 million; September 30, 2007: US\$306 million; and December 31, 2007: US\$303 million.

NIR targets will also be adjusted upward (downward) by the surplus (shortfall) in program disbursements relative to the baseline projection. Program disbursements are defined as uncommitted external disbursements that are usable for the financing of the overall central government budget.

\section{External Program Disbursements (Baseline Projection)}

Cumulative flows from December 31, 2006

End-June 2007 (program projection)

End-July 2007 (program projection)

End-August 2007 (program projection)

End-September 2007 (program projection )

End-October 2007 (program projection)

End-November 2007 (program projection)

End-December 2007 (program projection)
(In millions of U.S. dollars)

\section{Targets on Net Domestic Assets}

Net domestic assets (NDA) of the BCP are defined as the difference between currency issue (provided by the $\mathrm{BCP}$ ) and the net international reserves (NIR) of the BCP, both measured based on end-of-period data. Data will be provided to the Fund by the BCP with a lag of not more than five days past the test date.

\begin{tabular}{lc}
\hline Outstanding stock as of: & $\begin{array}{c}\text { Ceiling } \\
\text { (In billions of guaranies) }\end{array}$ \\
\hline End-December 2006 & $-5,312$ \\
End-June 2007 (performance criterion) & $-6,645$ \\
End-July 2007 (program projection) & $-6,645$ \\
End-August 2007 (program projection) & $-6,656$ \\
End-September 2007 (performance criterion) & $-6,700$ \\
End-October 2007 (program projection) & $-6,732$ \\
End-November 2007 (program projection) & $-6,640$ \\
End-December 2007 (performance criterion) & $-6,016$ \\
\hline
\end{tabular}


For the purpose of NDA calculation, NIR will be converted into guaranies at an accounting exchange rate of G 5,100/US\$. The ceiling on NDA will be adjusted upward (downward) by the equivalent in guaranies of the downward (upward) adjustments made to the floor on the NIR of the BCP as described above.

NDA targets will also be adjusted downward (upward) by the surplus (shortfall) in program disbursements relative to the baseline projection. Program disbursements are defined as uncommitted external disbursements that are usable for the financing of the overall central government budget.

\section{Public Debt and Arrears Targets ${ }^{3}$}

\section{Targets on Contracting or Guaranteeing of New Nonconcessional External Debt} by the Public Sector

\begin{tabular}{lc}
\hline Cumulative flows from December 31, 2006: & $\begin{array}{c}\text { Ceiling } \\
\text { (In millions of U.S. dollars) }\end{array}$ \\
\hline End-June 2007 (performance criterion) & 500 \\
End-July 2007 (program projection) & 500 \\
End-August 2007 (program projection) & 500 \\
End-September 2007 (performance criterion) & 500 \\
End-October 2007 (program projection) & 500 \\
End-November 2007 (program projection) & 500 \\
End-December 2007 (performance criterion) & 500 \\
\hline
\end{tabular}

The limit applies to the contracting or guaranteeing by the public sector within the calendar year of new nonconcessional external debt with an original maturity of more than one year, including commitments contracted or guaranteed. ${ }^{4}$ For program purposes, a debt is concessional if it includes a grant element of at least 35 percent on the basis of currencyspecific discount rates based on the OECD commercial interest reference rates (CIRR). ${ }^{5}$

\footnotetext{
${ }^{3}$ The stock of debt does not include disputed claims to the following parties: Belgium's Ex-Herstal, a South African supplier; French and Swiss import verification companies; the National Bank of Argentina, and a syndicate of European and American banks following a Swiss court ruling against Paraguay in May 2005. Any of these claims that would be considered as debt will be added to the stock figure.

${ }^{4}$ The term "debt" has the meaning set forth in point No. 9 of the Guidelines on Performance Criteria with respect to Foreign Debt adopted on August 24, 2000 (Board Decision No. 12274-(00/85). In line with Paraguayan law, debt will be deemed contracted only if it has received approval by Congress.

${ }^{5}$ The grant element is calculated as the difference between the net present value (NPV) of debt and its nominal value, expressed as a percentage of the nominal value of the debt (i.e., Grant Element $=($ Nominal Value -
} 
Excluded from the limits are credits extended by the IMF and balance of payments support loans extended by multilateral and bilateral creditors. The Ministry of Finance will provide data to the Fund with a lag of not more than 30 days from the test date.

The concessionality of loans in currency baskets will be assessed on the basis of U.S. dollar interest rate tables. For loans with interest rates based on the internal policy of the creditors, the relevant interest rate to define concessionality will be the interest rate for each creditor at the time of the commitment. Loans or portions of loans extended in the context of a debt rescheduling or a debt reduction operation will be excluded from the ceiling.

\section{Performance Criterion on Short-Term External Debt of the Nonfinancial Public Sector}

As a continuous performance criterion, the NFPS will neither contract nor guarantee any short-term external debt during the program period. Short-term debt is defined as debt with a contractual maturity of one year or less. Excluded are normal import-related credits, forward contracts, swaps, and other futures market contracts. The public enterprises will provide the necessary information to the ministry of finance, which will provide the data to the Fund, with a lag of not more than 30 days from the test date.

\section{Performance Criteria on External Payments Arrears of the Public Sector}

\section{The Public Sector, excluding PETROPAR, will accumulate no new external arrears} during the program period. The stock of external arrears of the PS will be calculated based on the schedule of external payments obligations reported by SIGADE. Data on external arrears will be reconciled with the relevant creditors, and any necessary adjustments will be incorporated in these targets as they occur. For the purposes of this performance criterion, an arrear will be defined as a payment, which has not been made within 30 days after falling due. In addition, the public enterprises will report to the Ministry of Finance and the BCP arrears on any external debt that is not recorded under SIGADE. The same 30-day grace period will be applied to all external payments of public enterprises, except where explicit agreements exist with creditors on an extended grace period. The Ministry of Finance will provide the final data on the stock of public sector external arrears to the Fund, with a lag of not more than 30 days from the test date.

In addition, the government is engaged in good faith efforts to resolve overdue claims in dispute, and will attempt to negotiate and resolve these as soon as possible. Claims against

NPV) / Nominal Value). The NPV of debt is calculated by discounting the future element stream of payments of debt service due on this debt. For debt with a maturity of at least 15 years, the ten-year average CIRR will be used to calculate the NPV of debt. For debt with a maturity of less than 15 years, the six-month average CIRR will be used. For the purposes of the program, the CIRRs published by the OECD in December 2006 will be used. 
the state of Paraguay resulting from a judgment made by the Swiss Federal Supreme Court on May 31, 2005, will be considered claims in dispute.

\section{Reporting}

Monitoring the program requires accurate and timely data. All information on performance criteria, indicative targets, and balance of payments support loans will be reported to Fund staff within the timeframes prescribed above. Debt stocks and associated flows broken down by both creditor and debtor types and maturity will be provided on a quarterly basis.

The Ministry of Finance will be responsible for gathering data on a monthly basis from all the institutions that comprise the consolidated public sector, including the incorporated enterprises (Sociedades Anónimas) COPACO and ESSAP. It will compile this information according to the standard format of the Ministry of Finance's monthly financial situation report (Situación Financiera). The data will be supplied to the Fund and published on the Ministry of Finance's external website within 30 days of each test date. 


\section{APPEndix 4. Paraguay-Financial Sector IsSUeS}

\section{RECENT DEVELOPMENTS}

\section{The financial system in Paraguay is recovering from a period of financial}

distress. The regained macroeconomic stability provided a favorable environment for the recovery of financial intermediation and a gradual increase in the private credit-to-GDP ratio which had fallen significantly following the last financial crisis.

\section{Dollarization declined as stabilization took hold and confidence was recovered.}

The share of both assets and liabilities in foreign currency reached over 60 percent of the total in 2001 and dropped to around 50 percent in 2006. In addition, the average maturity of both assets and liabilities has started to lengthen gradually, reflecting an increased confidence in the financial system.

3. The soundness of the banking system has steadily improved. Capitalization ratios - capital over risk weighted assets - remain comfortable at around 20 percent, well above the 10 percent regulatory minimum. At the same time, non-performing loans have significantly declined from almost 20 percent during the crisis in 2002 to 5 percent in 2006. Profitability has also recovered; the return on assets increased from 1 percent to 3.5 percent during the same period.

Credit to the Private Sector (\% of GDP)

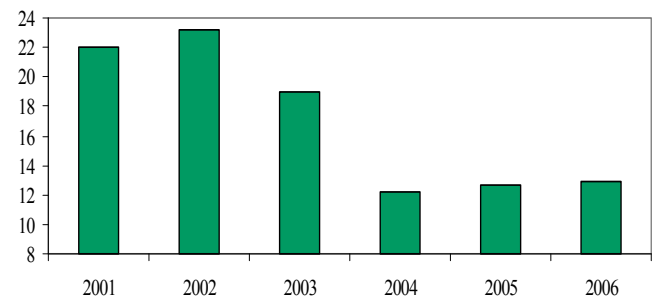

4. However, the soundness of the system may be overstated by weak prudential standards. Regulations on loans classification, provisioning requirements, and collateral use need to be improved. ${ }^{1}$ The superintendence of banks (SB) needs to enhance its autonomy and resources to perform its duties adequately. The laws and regulations need to be strengthened for the proper supervisory oversight of bank policies, procedures and credit risk management practices. Overall, the level of compliance of Paraguay with Basel Core Principles for Effective Banking Supervision (BCPEBSs) is relatively low. ${ }^{2}$

\footnotetext{
${ }^{1}$ Paraguayan standards do not distinguish between tier 1 and tier 2 capital; there are no requirements for market risks; and weights for risky assets are low.

2 A regulation on loans classification and provisioning, known as "Resolución 8/03" was expected to enter into effect in January 2007 but was delayed until August 2008 due to pressures from vested interest. The resolution tightens arrears periods applied for each risk category, requires provisioning and information from borrowers, and limits the use of collateral. The authorities report that all banks and virtually all finance companies are in line with Resolución 8.
} 


\section{AdVAnCES SinCE THE 2005 FSAP}

\section{Although the condition of the banking system has improved, significant} challenges remain. Since the time of the FSAP, progress has been made in implementing the reforms needed to enhance the resiliency of the system, and to foster financial intermediation. Similarly, the public bank BNF has successfully recovered. However, progress in other reform areas has been limited.

6. The National Development Bank (BNF) regained its solvency. Riddled with nonperforming loans, BNF was insolvent after the 2002 crisis. However, the situation improved dramatically in the last two years. While the CAR was negative at end-2004, it improved to $18 \frac{1}{2}$ percent by end-December 2006 , eliminating the systemic risk generated by BNF in the past. Efforts should now concentrate on a medium-term strategy to restructure the bank. BNF's management is currently working on the design of such a strategy.

\section{The legal and regulatory framework for banking supervision and financial} intermediation needs to be brought in line with international standards. This is particularly important after the delay in the introduction of Resolución 8 to January 2008. Additional regulations related to banks' rating system, foreign open positions, or sanctioning procedures should be introduced. Amendments to the existing legal framework (in particular the general banking law) are needed to address these weaknesses.

\section{The payment system infrastructure} needs to be modernized. The payment system fails to comply with most of the Core Principles for Systemically Important Payment Systems, hampering the development of financial markets. A reform strategy remains a priority, including resolving a number of legal issues (such as settlement finality protection against bankruptcy, legal basis for dematerialization of securities, electronic documents and

\begin{tabular}{|c|c|c|}
\hline \multicolumn{3}{|c|}{ Paraguay: Progress Since the 2005 FSAP } \\
\hline Measure & Advances & Comments \\
\hline \multicolumn{3}{|c|}{ Regulations and Supervision } \\
\hline 1. Approve banking legislation & $\times$ & $\begin{array}{l}\text { Amendments to the banking law have } \\
\text { not been sent to Congress. }\end{array}$ \\
\hline $\begin{array}{l}\text { 2. Upgrade regulatory and } \\
\text { supervisory framework }\end{array}$ & $\times$ & Resolucion 8/03 was delayed. \\
\hline \multicolumn{3}{|c|}{ National Development Bank (BNF) } \\
\hline 3. Restructure BNF & $\checkmark$ & $\begin{array}{l}\text { Bank is now solvent. Authorities } \\
\text { designing medium-term strategy. }\end{array}$ \\
\hline \multicolumn{3}{|c|}{ Payment Systems } \\
\hline $\begin{array}{l}\text { 4. Approve payment system } \\
\text { legislation }\end{array}$ & $\checkmark$ & Authorities discussing draft legislation. \\
\hline 5. Establish RTGS and ACH & $\times$ & No progress observed. \\
\hline \multicolumn{3}{|c|}{ Capital Markets } \\
\hline $\begin{array}{l}\text { 6. Approve security deposits } \\
\text { legislation }\end{array}$ & $\checkmark$ & $\begin{array}{l}\text { Authorities and market paticipants are } \\
\text { discussing draft legislation. }\end{array}$ \\
\hline $\begin{array}{l}\text { 7. Establish an electronic } \\
\text { trading system }\end{array}$ & $\times$ & No progress observed. \\
\hline \multicolumn{3}{|c|}{ Cooperatives Sector } \\
\hline $\begin{array}{l}\text { 8. Strenghten INCOOP } \\
\text { supervisory capacity }\end{array}$ & $\checkmark$ & $\begin{array}{l}\text { INCOOP has started supervising largest } \\
\text { cooperatives. Working to enhance } \\
\text { its capabilities and establish a deposit } \\
\text { insurance scheme. }\end{array}$ \\
\hline \multicolumn{3}{|c|}{ Central Bank (BCP) } \\
\hline $\begin{array}{l}\text { 9. Strengthen financial position } \\
\text { of Central Bank }\end{array}$ & $\checkmark$ & Authorities are designing a strategy. \\
\hline
\end{tabular}
signatures), and introducing a Real Time Gross Settlements system (RTGS), and an Automated Clearing House $(\mathrm{ACH})$. Currently, the central bank is preparing a draft payment system law that would address a number of these issues.

9. Capital markets remain thin and underdeveloped. Activity is limited and market capitalization, at around US\$200 million (3 percent of GDP), is low. The main constraints are related to the high degree of informality of firms and to legal and infrastructure issues. Progress in this area has been limited. A draft law of security deposits is being considered by 
the authorities. Developing a market for government bonds in the context of a debt management strategy would help in the development of capital markets. A draft law on bond issuance is also being considered by the authorities.

\section{Financial cooperatives are steadily increasing their participation in the financial} system, accounting for about 25 percent of the market. Until 2004 cooperatives were largely unregulated, but advances have been made with the formalization of the role of INCOOP, and with regulations that defined their scope and established basic solvency, assets classification, and provisioning criteria. However, an effective supervisory framework is still absent. INCOOP has started consolidating financial information of the largest cooperatives and is designing, in cooperation with the IADB, a supervisory framework, a depositinsurance-type of fund, and a credit registry. Improving the quality of information provided by the sector remains a priority not only for supervisory purposes but also for the adequate measurement and control of monetary aggregates. Efforts should focus on the largest cooperatives at the initial stage.

\section{Paraguay and Its Peers: Supervision, Institutions And Information}

\section{Paraguay's financial development compares unfavorably to its peers in the}

region. Paraguay needs to implement a comprehensive strategy to bolster the performance of the financial system, including reforms to: (i) strengthen the regulatory and supervisory framework; (ii) improve creditors rights (and enhance the quality and quantity of economic and financial information of agents); and

\begin{tabular}{|lccc|}
\hline \multicolumn{4}{|c|}{ Paraguay: Financial Deepening and Economic Performance, 2005 } \\
\hline & $\begin{array}{c}\text { Private Sector } \\
\text { Credit } \\
\text { (\% of GDP) }\end{array}$ & $\begin{array}{c}\text { Market } \\
\text { Capitalization } \\
\text { (\% of GDP) }\end{array}$ & $\begin{array}{c}\text { GDP per } \\
\text { Capita } \\
\text { (US dollars) }\end{array}$ \\
\hline Paraguay & 13 & 3 & 1,289 \\
Latin America and Caribbean & 30 & 48 & 2,630 \\
\hline Source: IADB and Fund staff estimates. & & & \\
\hline
\end{tabular}
(iii) develop the incipient capital markets.

\section{The level of compliance with the Basel's Core Principles for Effective Banking} Supervision is relatively low. Paraguay's regulation and supervision compare less favorably to other countries in the region. Prudential regulations, requirements, banking supervision, and powers of supervisors need strengthening.

13. The legal framework needs to be strengthened to facilitate credit operations. The FSAP mission identified a number of legal weaknesses that hamper credit operations, especially when it comes to enforce the use of collaterals. In the international context, Latin America fares poorly compared to other regions in terms of creditor's rights and the rule of law. Paraguay performs even worse than other countries in Latin America when it comes to creditor's rights and the rule of law.

\begin{tabular}{|lcc|}
\hline \multicolumn{3}{|c|}{ Paraguay: Creditor Protection Comparisons } \\
\hline \multicolumn{1}{c}{ Country } & Creditor Rights & Rule of Law \\
\hline Paraguay & 0.25 & 0.34 \\
Latin America & 0.25 & 0.46 \\
Emerging Economies & 0.73 & 0.50 \\
OECD & 0.47 & 0.85 \\
\hline Source: IADB; La Porta et.al. (1997, 1998); Galindo and \\
Micco (2001); and Kaufman et al (2003). \\
1/ Index from 0 to 1. Proxy for "What the law says". \\
2/ Index from 0 to 1. Proxy for "Degree of law enforcement". \\
\hline
\end{tabular}




\section{Credit information plays an important role in the development of credit}

markets. Evidence suggests that the availability and quality of information is crucial for sound lending decisions. The existence of credit registries helps mitigate information asymmetry problems (e.g., moral hazard, adverse selection). According to the 2005 FSAP, credit information in Paraguay compares relatively well to other countries in the region and emerging economies, but financial

\begin{tabular}{|c|c|c|}
\hline \multicolumn{3}{|c|}{ Paraguay: Credit Information Comparisons } \\
\hline \multirow[b]{2}{*}{ Country } & \multicolumn{2}{|c|}{$1 /$} \\
\hline & $\begin{array}{l}\text { Private Credit } \\
\text { Bureau }\end{array}$ & $\begin{array}{l}\text { Public Credit } \\
\text { Registry }\end{array}$ \\
\hline Paraguay & 0.65 & 0.47 \\
\hline Mercosur & 0.69 & 0.49 \\
\hline Emerging Economies & 0.47 & 0.52 \\
\hline \multicolumn{3}{|c|}{$\begin{array}{l}\text { Source: IADB (2004); and various World Bank surveys. } \\
\text { 1/ Index from } 0 \text { to 1. Proxy for Quality of Private Credit Bureaus. } \\
2 \text { Index from } 0 \text { to 1. Proxy for Public Credit Registry. }\end{array}$} \\
\hline
\end{tabular}
institutions are grossly underutilizing the data available, in particular from the public registry.

\section{A Quick STRess Test}

\section{At the time of the 2005 FSAP, credit and exchange rate risks were the main} sources of potential instability for banks. Stress tests suggested that the main risks faced by banks were credit risks derived from a slowdown of economic activity, and exchange rate risks; while interest rate risk was more limited. In 2005, a depreciation of 20 percent and a slowdown in economic activity (to zero percent growth in real GDP) would reduce the capital adequacy ratio of the system from 20 to $17-18$ percent. $^{3}$

\section{The system appears more resilient} nowadays. The system is still more sensitive to shocks to the exchange rate and to the economic activity than to the interest rate; however, the negative effects are somewhat more limited. For example, the same exchange rate shock would reduce the CAR from 21 to 19 percent. The higher resilience may be the result of lower dollarization, and improvements in the maturity profile. ${ }^{4}$ Also, as mentioned above, another positive factor may be that banks have been applying a better risk-assessment

\begin{tabular}{|c|c|c|c|c|}
\hline \multicolumn{5}{|c|}{ Paraguay: Stress Trests on Capital Adequacy Ratios (CAR) } \\
\hline \multirow[b]{2}{*}{ Shocks } & \multicolumn{2}{|c|}{ December 2004} & \multicolumn{2}{|c|}{ September 2006} \\
\hline & $\begin{array}{c}\% \text { Change } \\
\text { in CAR }\end{array}$ & $\begin{array}{l}\text { CAR After } \\
\text { Shock \% }\end{array}$ & $\begin{array}{l}\text { \% Change } \\
\text { in CAR }\end{array}$ & $\begin{array}{l}\text { CAR After } \\
\text { Shock \% }\end{array}$ \\
\hline \multicolumn{5}{|l|}{ Economic Growth } \\
\hline Growth at $3 \%$ & -3.4 & 19.6 & -3.4 & 19.9 \\
\hline Growth at $0 \%$ & -9.4 & 18.4 & -8.5 & 18.9 \\
\hline \multicolumn{5}{|l|}{ Exchange Rate } \\
\hline Devalues $10 \%$ & -7.4 & 18.8 & -4.9 & 19.6 \\
\hline Devalues $20 \%$ & -14.8 & 17.3 & -9.7 & 18.6 \\
\hline \multicolumn{5}{|l|}{ Interest Rate } \\
\hline Up by 500 points & -6.4 & 19.0 & -2.9 & 20.0 \\
\hline Up by 1000 points & -7.9 & 18.7 & -7.3 & 19.1 \\
\hline Memorandum item: & & & & \\
\hline Initial CAR & 20.3 & $\ldots$ & 20.6 & $\ldots$ \\
\hline
\end{tabular}
framework.

17. Extreme scenario. An extreme scenario, which assumes negative real GDP growth of 3 percent; a depreciation of 40 percent; and an increase in interest rates of 20 percentage points would reduce the CAR from 21 to about 7 percent, well below the regulatory minimum.

\footnotetext{
${ }^{3}$ See "Paraguay FSAP: Stress Testing of Financial System Soundness" for a description of the methodology.

${ }^{4}$ Since end-2004 the maturity gap has declined from 35 days to almost zero.
} 


\section{ApPendix 5. Paraguay- Debt Sustainability Analysis}

1. Following the rapid decline in Paraguay's debt-to-GDP ratio over the past five years, it is projected to decline further under the baseline debt sustainability scenario. Paraguay's economic stabilization following the crisis in 2002 was accompanied by an impressive reduction of the public debt burden from $71 \frac{3}{4}$ percent of GDP to $271 / 2$ percent of GDP at end-2006. Going forward, economic growth would average close to 5 percent a year over the medium term with the overall position of the combined public sector in balance. Under these assumptions, Paraguay's public sector debt stock would decline further to about 22 percent of GDP by 2012.

2. Given that 80 percent of total external debt is public, in the baseline scenario the projected drop in public debt largely determines the path of Paraguay's total external debt. Private sector external debt is projected to increase slightly as direct investments by foreign companies are also accompanied by some debt creating flows. Nevertheless, total external debt is projected to decline from 333/4 percent of GDP at end-2006 to 29 percent by 2012 .

3. Paraguay's external and public sector debt ratios are robust to alternative assumptions about underlying macroeconomic variables. Sensitivity tests based on 10-year historical standard deviations to form alternative medium-term assumptions for real GDP growth and interest rates show that Paraguay's debt dynamics are only moderately vulnerable to such changes. For example, a 1/1/4 percent decline on average of annual growth over the medium term would imply an increase in the debt-to-GDP ratio of 2 percent of external debt and 8 percent of public debt by 2012 .

4. By contrast, given the high foreign currency share of Paraguay's debt the projected debt path is rather sensitive to exchange rate changes. Specifically, under a one time 30 percent depreciation of the guaraní in 2008, the external debt-to-GDP ratio would shift by 11 percentage points above the baseline projections in the medium term. Non-interest current account shocks (such as in the terms of trade) would have a moderate adverse impact on external indebtedness.

\section{A similar pattern is observed under a 10 percent of GDP shock to contingent}

liabilities of the public sector. The public debt-to-GDP ratio would rise sharply in the short run and, while declining over the medium term, would remain 10 percentage points above the debt levels projected under the baseline scenario. 


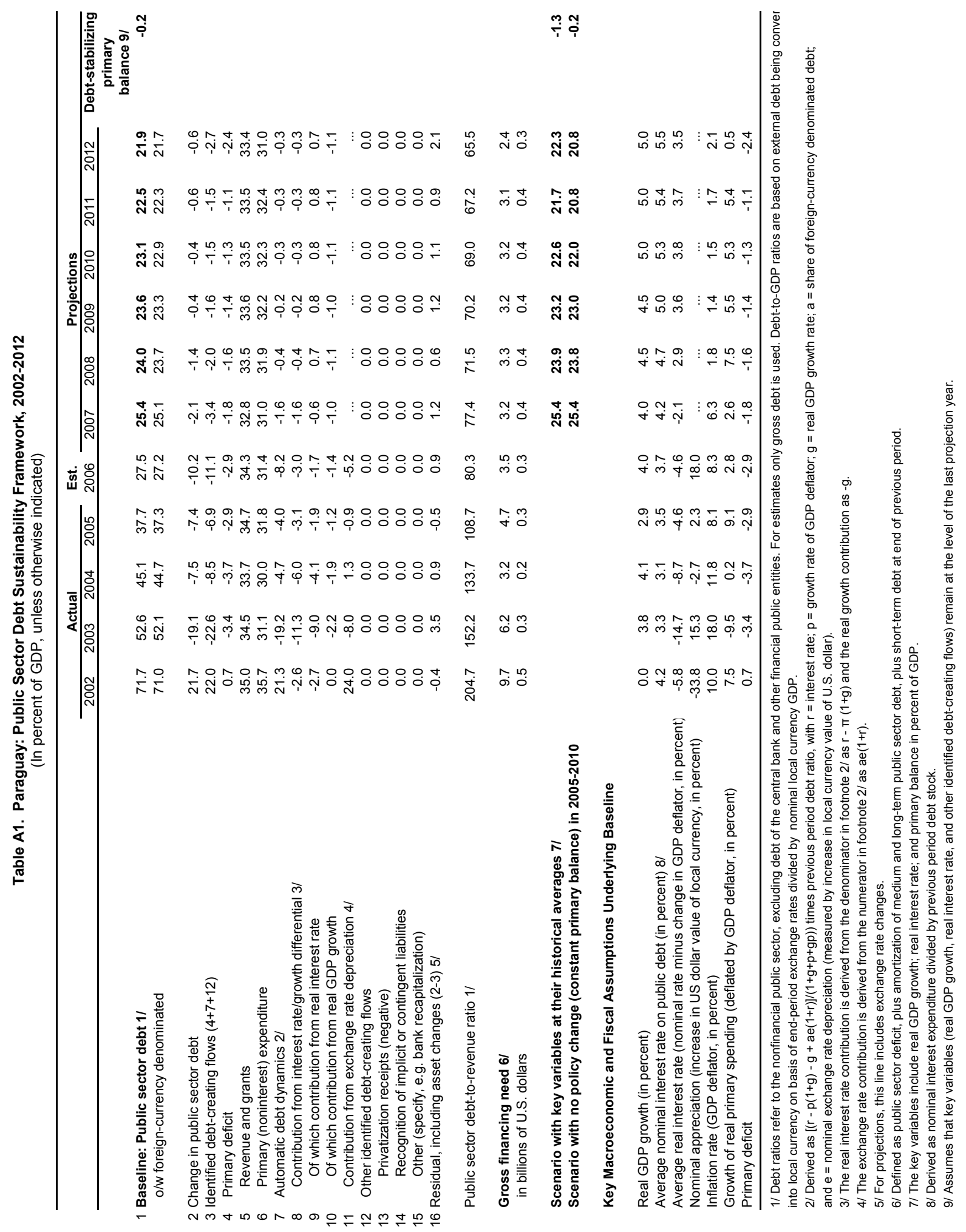




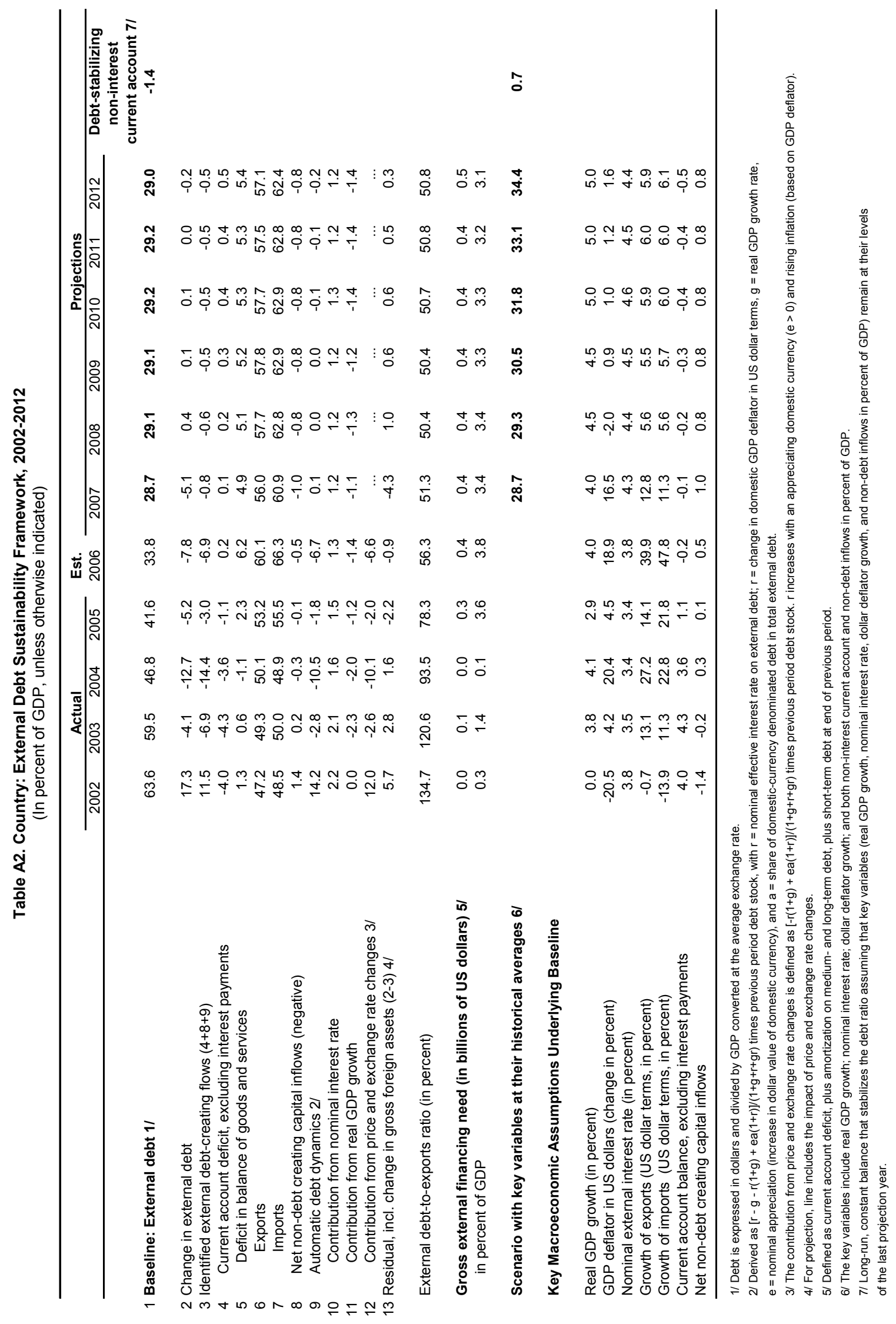


Figure A1. Paraguay: Public Debt Sustainability: Bound Tests 1/ (Public debt in percent of GDP)
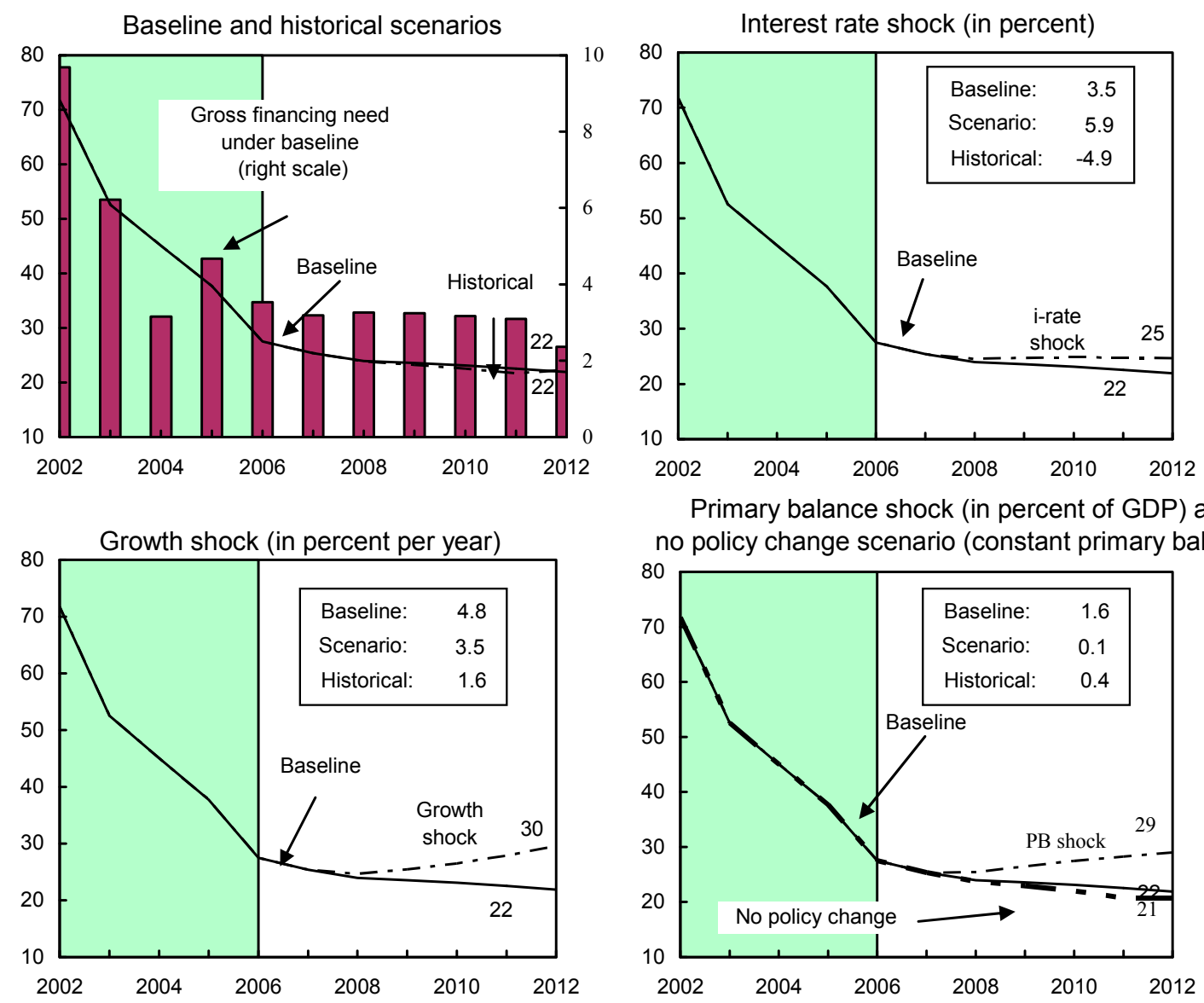

Primary balance shock (in percent of GDP) and no policy change scenario (constant primary balance)

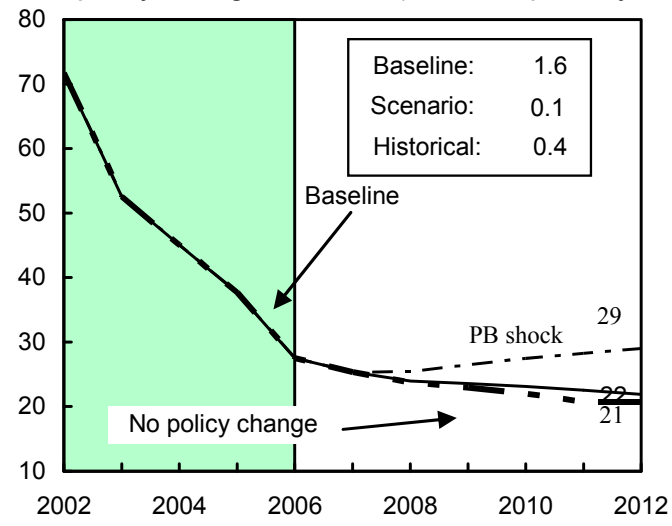

Combined shock 2/

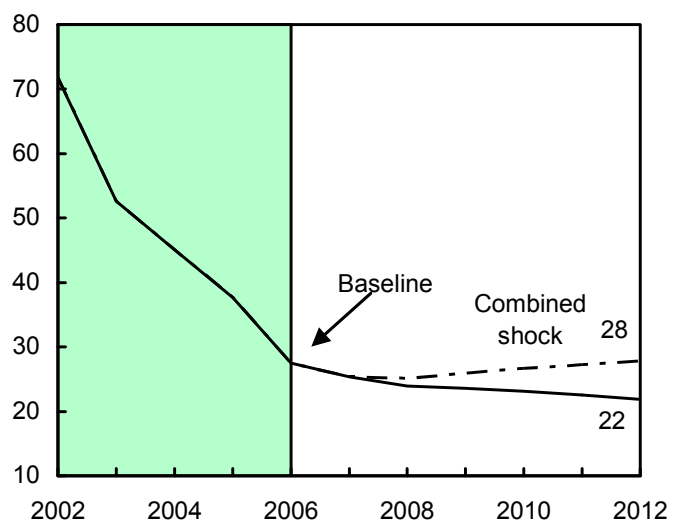

Real depreciation and contingent liabilities shocks 3/

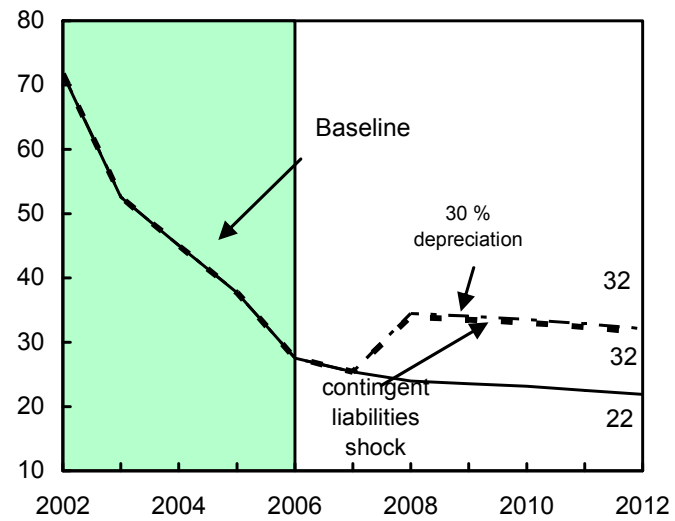

Sources: International Monetary Fund, country desk data, and staff estimates.

1/ Shaded areas represent actual data. Individual shocks are permanent one-half standard deviation shocks. Figures in the boxes represent average projections for the respective variables in the baseline and scenario being presented. Ten-year historical average for the variable is also shown.

2/ Permanent 1/4 standard deviation shocks applied to real interest rate, growth rate, and primary balance.

$3 /$ One-time real depreciation of 30 percent and 10 percent of GDP shock to contingent liabilities occur in 2008, with real depreciation defined as nominal depreciation (measured by percentage fall in dollar value of local currency) minus domestic inflation (based on GDP deflator). 
Figure A2. Paraguay: External Debt Sustainability: Bound Tests 1/ (External debt in percent of GDP)
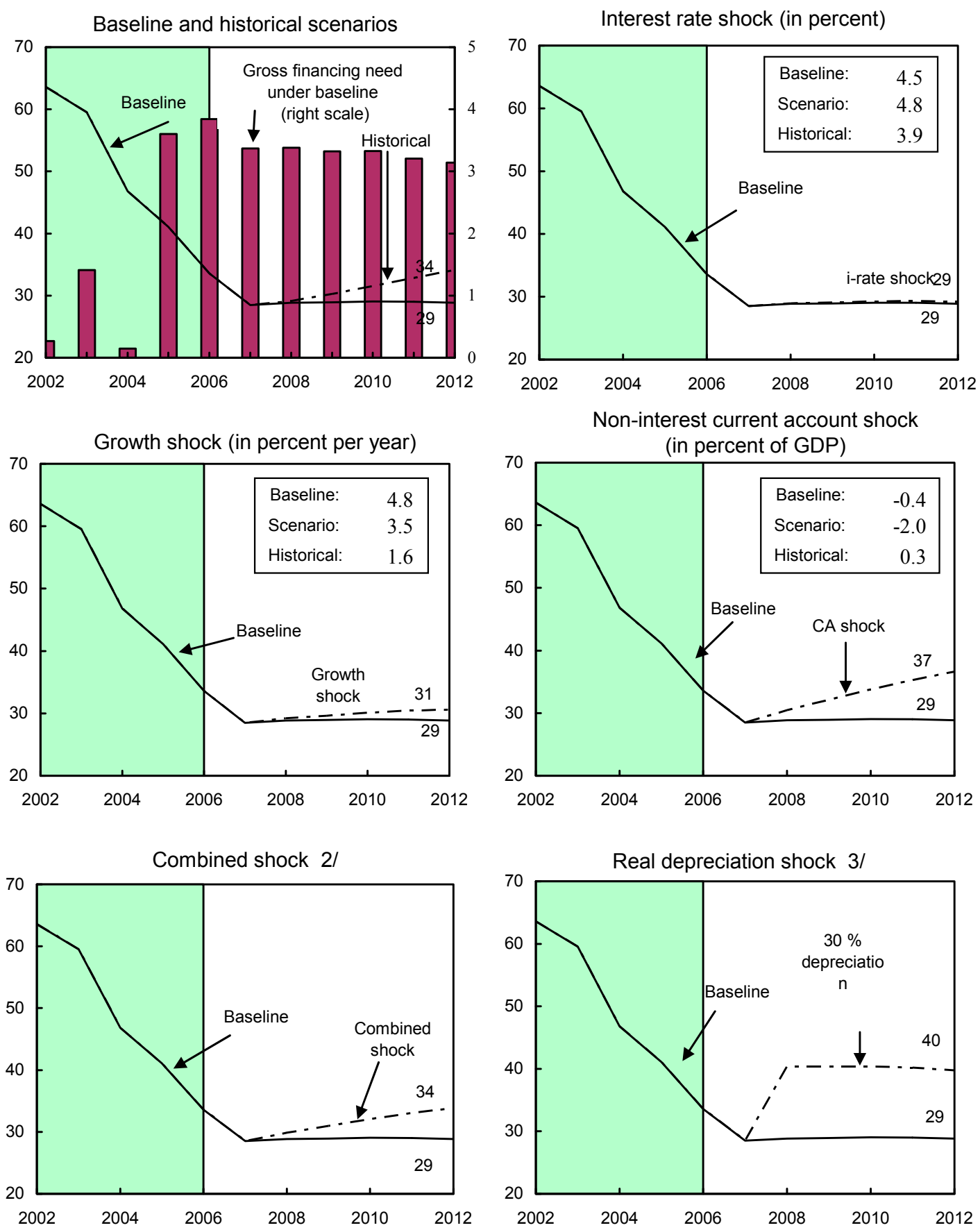

Sources: International Monetary Fund, Country desk data, and staff estimates.

$1 /$ Shaded areas represent actual data. Individual shocks are permanent one-half standard deviation shocks. Figures in the boxes represent average projections for the respective variables in the baseline and scenario being presented. Ten-year historical average for the variable is also shown.

2/ Permanent 1/4 standard deviation shocks applied to real interest rate, growth rate, and current account balance.

3/ One-time real depreciation of 30 percent occurs in 2008. 


\section{Appendix 6. Paraguay-Technical Assistance Program}

1. The technical assistance (TA) program for Paraguay has been designed in close collaboration with functional departments to support the main objectives of the SBA program. Accordingly, the Fund TA strategy will concentrate on supporting reforms in the following policy pillars of the program: (i) public sector reform; (ii) financial sector reform; (iii) a pro-growth reform agenda; and (iv) a social safety net. Fund TA in the area of statistics will support Paraguay's objective of meeting international statistical standards. In all these areas, technical assistance has been planned to support the authorities' efforts preceding the adoption of key structural measures.

2. Public sector reform. This is needed to address remaining fiscal vulnerabilities and rigidities, including institutionalizing the improvement in revenue collection, improving budgetary planning and expenditure control.

3. Financial sector reform. This key reform area includes strengthening the functioning of the commercial banks, the Central Bank, public banks, and financial cooperatives to reduce vulnerabilities in the system.

4. Pro-growth reform agenda. In the first year, the program will focus on restructuring public enterprises and in steps to improve investment climate. The World Bank and IDB are assisting the authorities in these efforts.

5. Social safety net. This reform pillar is needed to protect the most vulnerable segments of society and to alleviate poverty. Following the successful introduction of this program to 8,800 families living under extreme poverty in 2006 , the challenge for 2007 is to strengthen the monitoring mechanisms and the required provision of health and education services while at the same time increasing the number of families receiving these transfers. The IDB is expected to provide TA for this purpose.

6. Statistics. The Report on the Observance of Standards and Codes (ROSC 2006) mission found that there is a need for improvements in almost all sectoral statistics. To address most of these weaknesses, TA would need to be programmed.

7. Schedule. The following Table presents detailed TA needs and the planned schedules for TA provision. 


\section{Paraguay: Technical Assistance to Support Structural Reforms}

\begin{tabular}{|c|c|c|}
\hline Area & Task & Dates \\
\hline \multirow[t]{5}{*}{$\begin{array}{l}\text { Public sector } \\
\text { reforms }\end{array}$} & $\begin{array}{l}\text { Strengthening tax administration. Following the design of a } \\
\text { draft tax procedures code in December 2006, the Ministry of } \\
\text { Finance will prepare the implementing regulations for such tax } \\
\text { procedures code (structural benchmark for end-September 2007). }\end{array}$ & $\begin{array}{l}\text { FAD, second and fourth } \\
\text { quarter of } 2007 .\end{array}$ \\
\hline & $\begin{array}{l}\text { Customs administration. Implementation of a modern } \\
\text { organizational structure, enhancement of computerized clearance } \\
\text { system, and transfer of collections to banking system. }\end{array}$ & $\begin{array}{l}\text { Peripatetic FAD advisor, } \\
\text { starting in March } 2007 .\end{array}$ \\
\hline & $\begin{array}{l}\text { Current expenditure management. Following the design of an } \\
\text { action plan to develop effective commitment control systems for } \\
\text { the public sector in June 2006, the Ministry of Finance will } \\
\text { establish an expenditure control system at the commitment level } \\
\text { for the Executive Branch (structural benchmark for end-December } \\
\text { 2007). }\end{array}$ & $\begin{array}{l}\text { FAD, third quarter of } \\
2007 \text { (to be approved). }\end{array}$ \\
\hline & $\begin{array}{l}\text { Capital expenditure management. The Ministry of Finance will } \\
\text { design a public sector investment system to improve prioritization, } \\
\text { efficiency, maximize investment return, and ensure that programs } \\
\text { reflect the government priorities (structural benchmark for end- } \\
\text { December 2007) }\end{array}$ & $\begin{array}{l}\text { IDB, third quarter of } \\
2007 .\end{array}$ \\
\hline & $\begin{array}{l}\text { Pension reforms. The Ministry of Finance will develop an action } \\
\text { plan for a pension reform aimed at ensuring its long-term } \\
\text { solvency, appropriately endorsed by the Economic Cabinet } \\
\text { (structural benchmark for end-September 2007). }\end{array}$ & $\begin{array}{l}\text { World Bank, second } \\
\text { quarter of } 2007 .\end{array}$ \\
\hline \multirow[t]{3}{*}{$\begin{array}{l}\text { Financial Sector } \\
\text { Reform }\end{array}$} & $\begin{array}{l}\text { Strengthening financial position of the central bank. The } \\
\text { authorities will prepare a plan to strengthen the financial position } \\
\text { of the Central Bank (structural benchmark for end-June 2007) and } \\
\text { submit to Congress the legislation necessary for its } \\
\text { implementation (structural benchmark for end-September 2007). }\end{array}$ & $\begin{array}{l}\text { MCM will provide TA } \\
\text { from headquarters, } \\
\text { starting in first quarter of } \\
2007 .\end{array}$ \\
\hline & $\begin{array}{l}\text { Strengthening regulations and supervisory framework of the } \\
\text { banking system. A new ambitious plan to strengthen financial } \\
\text { sector reform to increase coverage of Basel Core Principles of } \\
\text { banking supervision (structural benchmark for end-June 2007). }\end{array}$ & $\begin{array}{l}\text { MCM, second quarter of } \\
2007 .\end{array}$ \\
\hline & $\begin{array}{l}\text { Financial cooperatives' prudential regulations. To reduce } \\
\text { regulatory and supervisory differences between financial } \\
\text { institutions, and reduce vulnerabilities to the financial system, } \\
\text { INCOOP will develop an effective supervisory and regulatory } \\
\text { framework for financial cooperatives (structural benchmark for } \\
\text { end-September 2007). }\end{array}$ & $\begin{array}{l}\text { IDB, second quarter of } \\
2007 .\end{array}$ \\
\hline
\end{tabular}




\begin{tabular}{|c|c|c|}
\hline Area & Task & Dates \\
\hline \multirow[t]{4}{*}{$\begin{array}{l}\text { Financial Sector } \\
\text { Reform }\end{array}$} & $\begin{array}{l}\text { Payment system reforms. The Central Bank will implement the } \\
\text { regulatory framework addressing weaknesses in the payment } \\
\text { system, and in consultation with the government, will prepare a } \\
\text { draft payments system law approved by the economic cabinet } \\
\text { (structural benchmark for end-September 2007). }\end{array}$ & $\begin{array}{l}\text { MCM, third quarter of } \\
2007 .\end{array}$ \\
\hline & $\begin{array}{l}\text { Capital markets development. The Ministry of Finance, in } \\
\text { coordination with the Central Bank, will design a strategy for the } \\
\text { development of capital markets by end-December } 2007 \text { (structural } \\
\text { benchmark). }\end{array}$ & $\begin{array}{l}\text { MCM, second quarter of } \\
2007 .\end{array}$ \\
\hline & $\begin{array}{l}\text { AML/CFT and economic laws. The authorities are intending to } \\
\text { strengthen Paraguay's regulatory system for fighting financial } \\
\text { crime and abuse, and enhancing economic laws (e.g., creditor } \\
\text { rights). }\end{array}$ & $\begin{array}{l}\text { LEG, from second } \\
\text { quarter of } 2007\end{array}$ \\
\hline & $\begin{array}{l}\text { Strengthen and restructure the National Development Bank } \\
\text { (BNF) to reduce vulnerabilities in the system. Audited and } \\
\text { inspected CAR for BNF of } 10 \text { percent in December } 2006 \\
\text { (performance criterion for end-March 2007). }\end{array}$ & $\begin{array}{l}\text { MCM to review audit, } \\
\text { second quarter of } 2007 .\end{array}$ \\
\hline \multirow[t]{2}{*}{$\begin{array}{l}\text { Pro-Growth } \\
\text { Reforms }\end{array}$} & $\begin{array}{l}\text { Improve business climate. Following the design of a master plan } \\
\text { to help promote the investment climate in September 2006, the } \\
\text { Ministry of Industry will implement such plan (structural } \\
\text { benchmark for end-September 2007). }\end{array}$ & $\begin{array}{l}\text { IDB and World Bank, } \\
\text { from first quarter of } \\
2007 .\end{array}$ \\
\hline & $\begin{array}{l}\text { Restructuring public enterprises. Following the design of } \\
\text { results-oriented management contracts with ANDE, COPACO, } \\
\text { ESSAP, INC, and PETROPAR, there will be need to assess these } \\
\text { contracts (structural benchmark for end-December 2007). }\end{array}$ & $\begin{array}{l}\text { World Bank and IDB, } \\
\text { from third quarter of } \\
2007 .\end{array}$ \\
\hline Social Safety Net & $\begin{array}{l}\text { Protect the most vulnerable segment of the population and } \\
\text { alleviate poverty. The Ministry of Social Action will aim at } \\
\text { widening the coverage of the social assistance program to } 15,000 \\
\text { families (structural benchmark for end-December 2007). }\end{array}$ & $\begin{array}{l}\text { IDB, from first quarter of } \\
2007 .\end{array}$ \\
\hline \multirow[t]{2}{*}{ Statistics } & $\begin{array}{l}\text { Monetary and financial. Expand coverage of monetary statistics } \\
\text { to include deposit-taking cooperatives. }\end{array}$ & $\begin{array}{l}\text { STA follow-up mission, } \\
\text { (to be programmed). }\end{array}$ \\
\hline & $\begin{array}{l}\text { Follow-up to the } \mathbf{2 0 0 6} \text { data ROSC mission. Evaluate } \\
\text { implementation of major recommendations of the } 2006 \text { data } \\
\text { ROSC mission including: (i) improving the methodological } \\
\text { quality of national accounts and government finance statistics; } \\
\text { (ii) establish regular mechanisms for enhancing intersectoral data } \\
\text { consistency, (iii) strengthen data sources across all data sets, } \\
\text { including the conduct of surveys and census, and (iv) adopt } \\
\text { advance release calendar for all statistics. }\end{array}$ & STA TA to be requested. \\
\hline
\end{tabular}




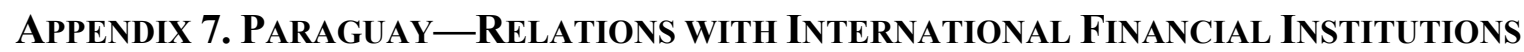

The full annexes are available as a separate document. They can be viewed in CyberDocs on the Fund's intranet and on the secure extranet for Executive Directors and member officials.

\section{Fund Relations}

Paraguay has no current outstanding debt to the Fund. The authorities have treated as precautionary the previous SBA (which covered December 2003 to November 2005), and the current SBA (which will cover May 2006 to August 2008). Paraguay's exchange rate regime is a managed float, the exchange rate is determined in the inter-bank foreign exchange market, with occasional Central Bank interventions to smooth out seasonal fluctuations. The Central Bank is implementing proposed measures to address the vulnerabilities identified in the Safeguards Assessment completed in October 2006. The last article IV consultation was concluded by the Executive Board on July 30, 2004.

\section{Relations with the World Bank Group ${ }^{1}$}

The Country Assistance Strategy (CAS) was approved in December 2003. The Bank's involvement aims at restoring confidence in the economy and to support reforms in financial sector, rural development, health and education. As of December 2006, the Bank's loan commitments amount to US\$169 million, of which US\$124 million remain undisbursed. In addition, the Bank is also involved in technical cooperation projects for US\$5 million.

\section{Relations with the Inter-American Development Bank ${ }^{2}$}

A review of the IDB's Country Strategy was approved in November 2006. The main focus of the IDB's activities for 2007-08 will be support to economic growth and poverty alleviation. As of December 31, 2006, the IDB's active loan portfolio amounts to US\$739 million, of which US\$445 million is undisbursed, in part because of delays in Congress. The IDB is also involved in technical cooperation operations for US\$22 million.

\section{Statistical Issues}

While data provision is broadly adequate for surveillance and program purposes, it is necessary to improve the timeliness and accuracy of macroeconomic statistics. Paraguay is a participant of the General Data Dissemination System since 2001. A ROSC data module was completed in June 2006 and identified a number of shortcomings in the coverage and methodological soundness of national accounts and government statistics. Money, banking, and balance of payments statistics are broadly reliable, but the other depository corporations survey should be expanded to include also the largest credit unions.

\footnotetext{
${ }^{1}$ Adapted from text prepared by the staff of the World Bank.

${ }^{2}$ Adapted from text prepared by the staff of the IDB.
} 
AnNex 1. Paraguay-Fund Relations

(As of May 31, 2007)

I. Membership Status: Joined December 28, 1945; Article VIII

II. General Resources Account:

Quota

Fund holdings of currency

Reserve position in Fund

III. SDR Department:

Net cumulative allocation

Holdings

\section{In millions \\ of SDRs}

99.90

78.43

21.48

In millions

of SDRs

13.70

92.58
In percent

of Quota

100.00

78.51

21.50

Percent of

Allocation

100.00

675.90

IV. Outstanding Purchases and Loans: None

V. Latest Financial Arrangements:

$\begin{array}{lcccr}\text { Type } & \text { Approval } & \begin{array}{c}\text { Expiration } \\ \text { Date }\end{array} & \begin{array}{c}\text { Amount Approved } \\ \text { (SDR Million) }\end{array} & \begin{array}{r}\text { Amount Drawn } \\ \text { (SDR Million) }\end{array} \\ \text { Stand-By } & \text { May 31, 2006 } & \text { Aug 31, 2008 } & 65.00 & 0.00 \\ \text { Stand-By } & \text { Dec 15, 2003 } & \text { Nov 30, 2005 } & 50.00 & 0.00\end{array}$

\section{Projected Payments to Fund}

(SDR Million; based on existing use of resources and present holdings of SDRs):

Principal

\begin{tabular}{lcccc}
\multicolumn{5}{c}{ Forthcoming } \\
\hline$\underline{2006}$ & $\underline{2007}$ & $\underline{2008}$ & $\underline{2009}$ & $\underline{2010}$
\end{tabular}

Charges/Interest

0.00

0.00

0.00

0.00

Total

0.00

0.00

0.00

0.00

VII. Exchange Rate Arrangement: The currency of Paraguay is the Paraguayan guaraní. The exchange rate regime is a managed float. The exchange rate is determined in the interbank foreign exchange market, but the central bank intervenes in the foreign exchange and monetary markets to smooth out exchange rate fluctuations in real effective terms. The U.S. dollar is the principal intervention currency. On April 30, 2007, the average interbank rate for the U.S. dollar was G5,115=US\$1. Paraguay has accepted the obligations of Article VIII, Sections 2(a), 3 and 4 of the Fund's Articles of Agreement. Staff is considering whether 
the application of the income tax regime and the new Law of Administrative Reorganization and Financial Adequacy (Ley No. 2421/04) may give rise to exchange restrictions subject to Fund jurisdiction.

VIII. Article IV Consultation: The Executive Board concluded the 2004 Article IV consultation on July 30, 2004; the document is IMF Country Report No. 05/59.

\section{Technical Assistance:}

\begin{tabular}{|c|c|c|}
\hline Department & Purpose & Date of Delivery \\
\hline MAE & Policy Advisory to the Central Bank & March 1994-2004 \\
\hline FAD & Tax Policy & February 1999 \\
\hline FAD & Tax Administration & March 1999 \\
\hline STA & Monetary Statistics & February 2000 \\
\hline STA & Balance of Payments Statistics & June 2000 \\
\hline STA & Multisector, GDDS accession & February 2001 \\
\hline MAE & Currency Operations & March-September 2002 \\
\hline FAD & Customs Administration & May 2002 \\
\hline MAE & Financial Sector Surveillance & July 2002 \\
\hline FAD & ROSC & August 2002 \\
\hline STA & Multisector, follow-up & September 2002 \\
\hline MAE & Banking Supervision & September-November 2002 \\
\hline MAE & Central Bank Operations & November 2002 \\
\hline TRE & Safeguards Assessment & January 2003 \\
\hline MFD & Banking Supervision & January 2003-April 2004 \\
\hline MFD & Currency Handling and Reform & February 2002-April 2004 \\
\hline MFD & Payment System & July 2003 \\
\hline FAD & Customs and Tax Administration & December 2003 \\
\hline MFD & $\begin{array}{l}\text { Reorganization of the Central Bank and } \\
\text { Monetary Operations }\end{array}$ & January 2004 \\
\hline FAD & Customs Administration Advisor & July 2004-May 2005 \\
\hline
\end{tabular}




$\begin{array}{lll}\text { Department } & \text { Purpose } & \text { Date of Delivery } \\ \text { MFD } & \text { Monetary Operations and Monetary Policy } & \text { October 2004 } \\ & \text { Formulation } & \\ \text { MFD } & \text { Public Banking Restructuring } & \text { February 2005 } \\ \text { FAD } & \text { Customs and Tax Administration } & \text { February 2005 } \\ \text { MFD and WB } & \text { FSAP Mission } & \text { April 2005 and } \\ & & \text { July 2005 } \\ \text { FAD } & \text { Update of ROSC } & \text { September 2005 } \\ \text { STA } & \text { ROSC } & \text { January 25-February 8, } \\ & & 2006 \\ \text { MFD } & \text { Central Bank Recapitalization } & \text { March 7-16, 2006 } \\ \text { MFD } & \text { Peripatetic Banking Expert } & \text { October 2005, February and } \\ & & \text { August 2006. } \\ \text { FAD } & \text { Public Financial Management } & \text { March 13-24, 2006 } \\ \text { FIN } & \text { Safeguards Assessment } & \text { March 20-28, 2006 } \\ \text { STA } & \text { Consumer Price Index } & \text { April 24-May 5, 2006 } \\ \text { FAD and LEG } & \text { Tax Procedure Code } & \text { May 16-26, 2006 } \\ \text { LEG } & \text { Money Laundering } & \text { July 2006 } \\ \text { STA } & \text { Monetary and Financial Statistics } & \text { August 30-September 12, } \\ & & 2006 \\ \text { MCM } & \text { Payments System } & \text { October 2006 } \\ & & \end{array}$

X. Safeguards Assessment: Under the Fund's safeguards assessment policy, Central Bank of Paraguay (CBP) is subject to a full safeguard assessment in respect to the arrangement approved on May 31, 2006. A safeguards assessment of the CBP was completed in October 2006. The report states that while the CBP has made some progress in strengthening the safeguards framework since the 2003 safeguards assessment, vulnerabilities remain in certain areas such as financial reporting and program data reporting to the Fund.

XI. Resident Representative: Mr. Luis H. Duran-Downing has been appointed as senior resident representative since May 2005. 


\section{Annex 2. Paraguay-World Bank Relations ${ }^{1}$}

(As of June 6, 2007)

The Country Assistance Strategy (CAS) was approved on December 16, 2003, aiming at restoring confidence in the economy and to support reforms in areas, such as the financial sector, rural development, health, and education. At the moment the portfolio of the Bank consist of three operations, of which two are projects under implementation:

- $\quad$ Pilot Community Development (\$9m, approved in FY00); and

- $\quad$ Secondary Education Reform (\$24m, approved in FY02).

And one project awaiting Parliament approval:

- $\quad$ Road Maintenance Project (\$74m, approved on August 24, 2006)

The three World Bank-financed projects presently under implementation or awaiting ratification by parliament have a total value of US\$107 million in commitments, of which US\$90 million remain undisbursed as of June 6, 2007.

In addition to loans, the Bank has mobilized grants for the institutional strengthening of Congress $(\$ 0.4 \mathrm{~m})$ and the Ministry of Finance $(\$ 0.3 \mathrm{~m})$; to improve management of indigenous lands $(\$ 1.7 \mathrm{~m})$; to support social development $(\$ 0.9 \mathrm{~m})$; and to improve biodiversity and forestry $(\$ 0.3 \mathrm{~m}$ from the Institutional Development Fund, and $\$ 0.3 \mathrm{~m}$ and $\$ 0.9 \mathrm{~m}$ from the Global Environment Fund).

On the analytical, in FY07 the Bank has recently completed a Land Tax Study, and is preparing an Integrated Fiduciary Framework (jointly with the Interamerican Development Bank) and Education Attainment Assessment.

Projects under preparation include an additional financing for the Pilot Community Development Project, a Sustainable Rural Investment project, a Modernization of the Water Sector project, a Private Sector Development project, and a Forestry Project.

\footnotetext{
${ }^{1}$ Prepared by the staff of the World Bank.
} 


\title{
Financial Relations With The World Bank
}

(In millions of U.S. dollars)

I. IBRD/IDA Active Operations (as of June 6, 2007)

\author{
Committed \\ (Net of Cancellations)
}

Disbursed Undisbursed

Active loans

Community development

9.0

24.0

74.0

6.7

2.3

Education Reform

10.2

13.8

Road Maintenance*

107.0

16.9

74.0

Total active loans

\section{0}

$1,046.3$

Total IBRD/IDA

602.0

Repaid

252.8

Total outstanding

234.3

$\mathrm{O} / \mathrm{w}$ IDA

18.5

II. IFC Operations (as of June 6, 2007)

\begin{tabular}{lccr} 
& Loans & Equity & Total \\
\cline { 2 - 4 } & & & \\
Commitments & 15.0 & 0.0 & 15.0 \\
Held by IFC & 15.0 & 0.0 & 15.0 \\
Undisbursed & 0.0 & 0.0 & 0.0
\end{tabular}

III. IBRD/IDA Loan Transactions (calendar year) ${ }^{2}$

\begin{tabular}{lrrrrrrrrr} 
& 1998 & 1999 & 2000 & 2001 & 2002 & 2003 & 2004 & 2005 & 2006 \\
\hline Disbursements & 37.7 & 42.1 & 46.6 & 26.8 & 13.5 & 42.3 & 16.2 & 16.7 & 31.9 \\
Repayments & 24.6 & 24.6 & 20.2 & 15.3 & 16.8 & 21.0 & 34.8 & 26.6 & 27.5 \\
Net lending & 13.1 & 17.5 & 26.4 & 11.5 & -3.3 & 21.3 & -18.6 & -9.9 & 4.4 \\
\hline
\end{tabular}

\footnotetext{
${ }^{2}$ As of June 6, 2006.

* Not yet effective.
} 


\section{Annex 3. Paraguay-Inter-American Development Bank Relations ${ }^{1}$}

(As of May 31, 2007)

\section{Portfolio}

1. As of May 31, 2007, the active loan portfolio amounts to US\$743.6 million, with an undisbursed balance of US\$436.2 million. In addition, there are 67 active Technical Cooperation operations (regular TCs, MIF, and Small Projects) for US\$25.3 million, of which US\$13.3 million are undisbursed. Loan approvals in 2006 reached a new record level of US\$251.4 million.

\section{Strategy}

- A review of IDB's Country Strategy with Paraguay was approved in November, 2006. The main focus of IDB's actions for 2007-2008 will be the support of economic growth and poverty alleviation.

\section{Pipeline}

2. The lending program for 2007 includes the following operations:
a. Program to Support the Economic Census of Paraguay, US\$5.0 million
b. Program to Support Paraguayan Exports - REDIEX, US\$10 million
c. Guarantee of a Bond Issuance for the Development Financial Agency US\$25.0 million
d. "Escuela Viva II" and Professional Technical Education Program, US $\$ 45.0$ million.
e. Modernization of Fiscal Administration II, US\$9.0 million
f. Customs support, US\$5.0 million

\footnotetext{
${ }^{1}$ Prepared by the staff of the IDB.
} 


\section{AnNeX 4. Paraguay: Statistical Issues}

While data provision is broadly adequate for program purposes, there is a need to improve the timeliness and accurate reporting of statistics. Paraguay became a GDDS participant in September 2001 with the publication of its metadata on the Fund's Dissemination Standards Bulletin Board (DSBB). A data ROSC mission visited Paraguay in January-February 2006; the authorities' response to the report and the mission's recommendations are published on the Fund's website.

\section{A. Real Sector}

A new national accounts series - broadly consistent with the guidelines of the $1993 \mathrm{SNA}$ was released in 2005. It was prepared with the assistance of an expert financed by the IDB and comprises a more complete coverage of industries, an input-output matrix, and expanded data sources for the compilation of the new base year (1994). However, no comprehensive regular program for data collection of economic censuses and surveys exists (an industrial survey was conducted in 2002) and source data for nonfinancial services, household consumption, and changes in inventories are insufficient. Major areas of concern include: (i) the 1994 reference year is becoming obsolete; (ii) excessive use is made of fixed coefficients for value added and household consumption; (iii) changes in inventories are obtained residually; (iv) informal activities are not monitored; and (v) supply and use tables have been compiled only until 1997 while the periodicity of annual GDP meets GDDS recommendations, timeliness does not because data are disseminated with a lag of 11 months.

Both the consumer (CPI) and producer price indices (PPI) are reported on a regular and timely basis. The geographic coverage of the CPI is limited to Asunción (the capital) and expenditure weights are representative of the consumption patterns of urban households. The CPI has a base weight period of 1992, and the PPI of December 1995. The household budget survey 2005-2006, for which information is now being gathered, will be used as the basis for updating the CPI basket and weights and for developing the index in accordance with the classification and valuation systems established in 1993 SNA. The PPI basket (150 items) is still not fully representative of current national output; electricity, water, gas, and services are not covered by the PPI.

Since the introduction of a regular household survey in 1998, the coverage and quality of employment and unemployment statistics have improved significantly. However, frequencies remain at the annual level, and the publication lag is close to one year. Wage indices are updated twice a year.

The data ROSC mission found that the resources are insufficient for real sector statistics and constrain further development, particularly the full adoption of the 1993 SNA. 


\section{B. Fiscal Sector}

Paraguay's GFS are broadly consistent with the recommendations of the Manual on Government Finance Statistics 1986 (GFSM 1986). The authorities have not yet prepared a plan to migrate to the Government Finance Statistics Manual 2001 (GFSM 2001). Monthly data are available for the central administration (budgetary central government). Data on the operations of the local governments are not included in the GFS. The asset position of the social security system is available on a daily basis. Statistics on the central administration include data of the Postal Service Directorate (a nonfinancial public corporation) and the statistics of the nonfinancial public sector include data of financial public corporations (four employer social insurance schemes). These social insurance schemes are treated as financial corporations in the monetary and financial accounts. Data on medium- and long-term external debt are reliable and available on a monthly basis. Domestic debt data are available on request, but need to be fully integrated with the external debt database. Deficiencies remain in the registration of short-term supplier and commercial credit of the public sector. Moreover, there is a discrepancy in the fiscal data reported by the monetary and fiscal authorities. Measures are being taken to make reporting more transparent.

Annual data covering only budgetary central government through 2005 have been reported for publication in the 2006 edition of the GFS Yearbook. However, since 1994 no outstanding debt data and no breakdowns for expenditure by function data have been provided for publication in the GFS Yearbook. Monthly and quarterly data are not reported for publication in IFS. The resumption of reporting of quarterly and monthly data for the IFS is highly recommended.

\section{Money and Banking Sectors}

Money and banking statistics are broadly reliable because of the adoption of a new accounting plan for commercial banks and finance companies in 1995. Following the work on methodologies initiated in the 2000 STA mission, Paraguay completed the establishment of a unified compilation and reporting system for the whole range of monetary data. This new system intends to harmonize monetary data for use within the CBP, for reporting to STA for publication in IFS, and for operational and monitoring purposes. A revision of the classification criteria has led also to a marked reduction in the discrepancies of interbank positions. However, the lack of coverage of the credit cooperatives remains a matter of concern, since they account for around 25 percent of deposits and loans of the banking sector.

The superintendency of banks publishes a detailed and informative report on the soundness of the financial system. The authorities of Paraguay commenced submission of monetary statistics based on standardized report forms. 


\section{External Sector}

Quarterly and annual data on balance of payments and the international investment position (IIP) are available from 2001 onwards on the central bank website, and are reported to STA. Annual IIP data have been compiled and disseminated for the period 1995-2005 (quarterly data for the period Q12001-Q12006). The classification of the balance of payments and the IIP follows the recommendations of the Balance of Payments Manual, 5th edition. Improvements have been made in the quality of the data on capital flows, especially in the coverage of foreign direct investment, and in the recording of external debt transactions in the balance of payments and in the IIP. The central bank now produces a highly informative bulletin with balance of payments statistics. Special studies by the central bank have improved the estimation methods for remittances of Paraguayans abroad and unregistered trade transactions, but serious deficiencies remain.

Also, deficiencies remain in the area of private capital outflows, which are difficult to register due to Paraguay's open capital account. Major recommendations of the 2006 data ROSC mission include the need to: (i) design and conduct sample surveys to capture data for items currently excluded from balance of payments statistics or items not appropriately covered (e.g., some services, direct and portfolio investment abroad, real estate); (ii) review and update the statistical techniques to estimate unrecorded trade; (iii) prepare periodical reports to inform management of the CBP of the quality of survey's data (response, coverage, response errors); and (iv) initiate a process of quarterly reconciliation of flows and stocks of medium- and long-term external public debt with the MOF.

A follow up technical assistance mission on balance of payments statistics visited the $\mathrm{BCP}$ in November 2006. The main objective of the mission was to assist the BCP in implementing recommendations of the ROSC mission. In particular, the follow up mission focused on: (1) assessing the surveys used to capture data on services, direct investment, nonfinancial private sector portfolio investment, and other investment; (2) reviewing and updating the statistical techniques used to calculate unrecorded trade; (3) reassessing the treatment of the binational hydroelectric energy enterprises in the external sector accounts; and (4) reviewing and preparing a preliminary template for reporting data on international reserves and foreign currency liquidity. 
86

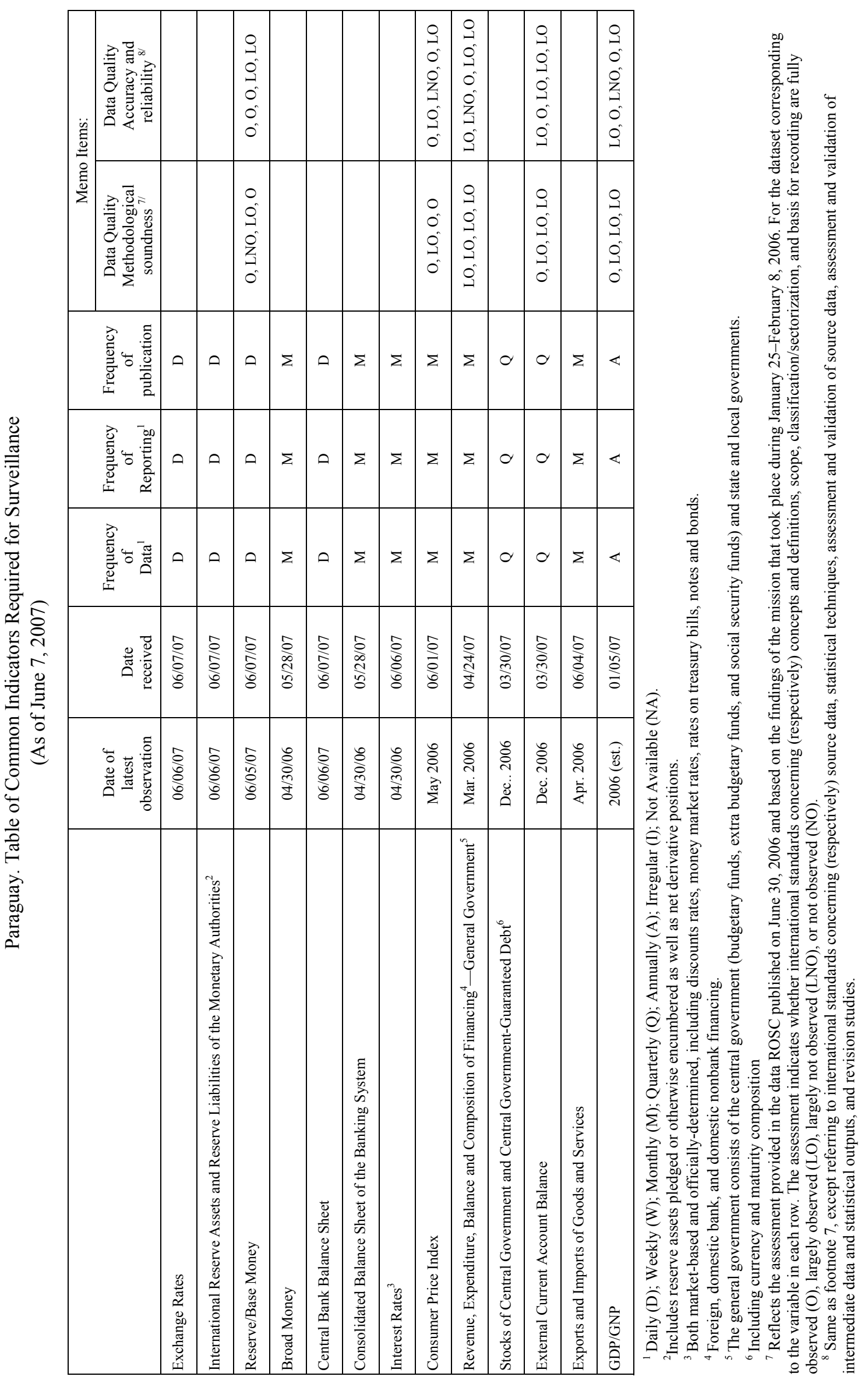


Annex 5. Paraguay-Work Program

Mission
Second and Third SBA Review and 2007 Article IV
Consultation

Consultation

Board Meeting

June 29, 2007

Fourth SBA Review

Mission

Jul 25-Aug 8, 2007

Board Meeting

September 14, 2007

Fifth SBA Review

Mission

Oct 24-Nov 7, 2007

Board Meeting

December 14, 2007

Memorandum items:

Approval of SBA

May 31, 2006

First SBA Review

September 29, 2006 
Press Release No. 07/150

International Monetary Fund

FOR IMMEDIATE RELEASE

Washington, D.C. 20431 USA

July 2, 2007

\section{IMF Executive Board Completes Second and Third Reviews under Paraguay's Stand-By Arrangement}

The Executive Board of the International Monetary Fund (IMF) completed on June 29, 2007, the second and third reviews of Paraguay's economic performance under a 27-month StandBy Arrangement in the amount equivalent to SDR 65 million (about US\$98.4 million). This will make SDR 43 million (about US\$65 million) available to Paraguay immediately. However, the Paraguayan authorities intend to continue treating the arrangement as precautionary. The arrangement was approved May 31, 2006 (see Press Release No. 06/117).

The main objectives of the program are to raise growth on a sustainable basis and to address widespread poverty. The program is centered around five reform areas: strengthening macroeconomic management, reinforcing fiscal institutions, tackling financial weaknesses, developing a pro-growth policy agenda, and designing an effective poverty reduction policy.

The Executive Board also concluded the Article IV Consultation with Paraguay.

Following the Board discussion on the second and third reviews, Takatoshi Kato, Deputy Managing Director and Acting Chair, said:

"Paraguay's economic performance over the past four years has been commendably strong, reversing decades of declining living standards. Since 2003, growth has rebounded to almost twice its long-term average, and extreme poverty has been reduced by almost one-third. The consolidated public debt-to-GDP ratio has been reduced by one half, inflation has been contained, the guarani has strengthened significantly, and international reserves have reached a historical peak. This progress is the result in large part of the government's determined efforts to establish fiscal and monetary discipline and entrench structural reforms.

"Performance under the Fund-supported program has been good. In particular, fiscal discipline was maintained despite rising expenditure pressures toward the end of 2006. Following supply shocks during the fourth quarter of 2006, inflation increased significantly, but there has been a substantial reduction in inflation since the beginning of this year. The 
outlook for economic activity in 2007 remains robust, with real GDP growth projected at 4-5 percent. However, there have been some delays in implementing financial sector reforms. In their medium-term strategy, the authorities are committed to entrenching macroeconomic stability, intensifying reforms to establish the conditions for sustained growth, and addressing remaining vulnerabilities in the financial sector. The authorities' policies will be aimed at creating an enabling environment for private sector-led growth and achieving a meaningful reduction in poverty.

"Going forward, there is a need for the authorities to implement without delay their new plan to strengthen the financial system. The current high profits and declining level of nonperforming loans in the financial system suggest that now would be a good opportunity for the authorities to improve the financial sector's regulatory and supervisory frameworks and the central bank's financial position.

"The Fund, through policy advice and technical assistance, will continue supporting the authorities in their efforts to address these challenges," Mr. Kato said. 


\section{Statement by Javier Silva-Ruete, Executive Director for Paraguay and Luis Enrique Salgueiro, Senior Advisor to Executive Director June 29, 2007}

1. Our Paraguayan authorities would like to thank the IMF staff for a well-written and comprehensive report, which clearly highlights and evidences the authorities' aim to pursue their macroeconomic objectives. They would also like to express their firm commitment to consolidating the stabilization efforts made so far and their intention to carry out their remaining goals in macroeconomic sustainability, as well as the structural reform agenda in order to ensure sustainable growth.

\section{Recent Economic Developments}

2. After the approval of the previous Stand-By Arrangement in 2003, the Paraguayan economy has shown significant economic progress, which has been broadly satisfactory and paved the way for further macroeconomic achievements. In particular, we concur with the staff's view that macroeconomic outcomes have been underpinned by a disciplined and coordinated fiscal and monetary policy. Consequently, the most important results were a near doubling of the long-term average real GDP growth after the 2002 financial crisis and the reduced level of extreme poverty. In fact, the estimated GDP growth was around 4 percent in 2006, which was better than projected and mainly driven by a significant increase in services, manufacturing, the agricultural sector — which is recovering after severe drought—, beef exports, and private investment in telecommunications.

3. Despite higher volatility in 2006 , a prudent monetary policy allowed core inflation to fall from 10 percent in 2005 to 7 percent in 2006, in line with the objective under the program. Headline inflation increased from 10 percent in 2005 to $12^{1 / 2}$ percent in 2006 as a result of supply shocks, namely stricter sanitary control in imported fruits and vegetables and increased beef exports which pushed up domestic prices, leading to a 12-month rate of 7 percent in May 2007. Although the large foreign exchange inflows - and consequently the necessary placements of Central Bank bills (LRM) to sterilize the foreign exchange excess in 2006 and the first five months of 2007-forced increases in the value of the currency, the Central Bank was skillful in putting a stop to the rapid appreciation, while also containing currency growth. In addition, the large foreign exchange inflow from royalties associated with the two bi-national hydroelectric plants strengthened the external position and took the Central Bank to a peak of international reserves, to US\$ 2.1 billion by end-May 2007.

4. On the fiscal front, prudent policies adopted in recent years reflected a stronger financial level, as a result of improved tax collections and controlled current expenditure. These were possible thanks to the implementation of a disciplined financial plan which resulted in a primary surplus of $1 \frac{1}{2}$ percent of GDP in 2006. In this regard, the authorities have prepared a tax procedure code which was approved by the economic cabinet in December 2006. The financial plan not only put financial issues in order, but also helped to 
regularize payments, eliminate arrears, and - its most important achievement - decrease the public debt-to-GDP ratio from around 70 percent in 2002 to an estimated $271 / 2$ percent in 2006. Public enterprises have adhered to this effort by signing a results-oriented management contract aimed to improve public services and financial ratios.

5. In the context of improved and sustained macroeconomic stability, the financial system, although in a smaller proportion, is recovering by restarting lending operations to the private sector, which grew by 18 percent in 2006, as dollarization fell from 65 percent of assets and liabilities in 2002 to almost 50 percent in 2006. Similarly, the banking system has lengthened the maturity of assets and liabilities and strengthened their position, reaching a capital adequacy ratio (CAR) of 20 percent, which is over the established minimum of 10 percent. The National Development Bank (BNF) has also regained its solvency over a short period, reaching a CAR under the IMF standard of $81 / 2$ percent in June 2006 (against a 5 percent target) and $18 \frac{1}{2}$ percent in December 2006 (against a 10 percent target) thanks to higher asset recovery and undistributed profits.

6. Regarding social reforms, the government has also reached significant achievements, such as decreasing the overall poverty index from almost 50 percent of the population in 2002 to 40 percent in 2005 . Social investments have also contributed to progress in education, with illiteracy rates declining from 10 percent in 1995 to 4 percent in 2005 .

\section{Fiscal Policy}

7. The fiscal authorities are committed to maintaining macroeconomic stability as a way to increase growth and reduce poverty. Along these lines, they are implementing several measures aimed to strengthen fiscal sustainability. In the short term, they are putting in practice a financial plan approved in March 2007 aimed to achieve a broader fiscal balance for 2007 by restraining current expenditure, while giving further opportunity for capital spending.

8. In the medium term, the authorities are cognizant of the need to improve fiscal policy flexibility and fiscal institutions, as well as promoting fiscal sustainability to facilitate their goal of achieving long-term growth and poverty alleviation through better social spending and infrastructure investment. In this regard, an agreement has been reached and several reforms are on track, such as enhancing the institutional framework of tax and customs administration to consolidate recent revenue gains. In fact, the strategy pursued by the government is to gradually increase the tax base and enhance administrative tax efficiency to enhance the tax-to-GDP ratio. In addition, strengthening public financial management to improve expenditure efficiency and control, reducing budget rigidities to allow further flexibility, rationalizing the civil service to improve service delivery; and reforming the pension regime to increase coverage and secure financial, complement the strategy.

9. In line with the identified weaknesses, the authorities have already drafted a tax procedures code and the implementing regulations are being prepared. In the same vein, in 
order to address current rigidities, improve control, rationalize expenditure and budgetary processes, and incorporate macroeconomic constraints, the Ministry of Finance will design an expenditure control system at the Central Government level, which will improve efficiency and quality in spending, as well as strengthening public financial management. Consistent with this purpose, the reduction in the number of accounts to a single one is currently in process, for which further assistance from the IMF is being requested. In this regard, in order to increase efficiency and priorities in capital expenditure, a public sector investment system will be designed with assistance from the IADB. Likewise, to complement the measures adopted in the past, an action plan aimed to ensure long-term solvency in pension systems will be developed.

10. In the same vein, public enterprises are following a management program based on results, and scheduled ratios by contract will be published by the Public Enterprises Supervising Council. This program plays an important role not only to contribute to providing better services, but also to set a productivity benchmark for the economy as a whole.

11. Turning to the funds budgeted in social investments, the government increased the budget by $12^{3 / 4}$ percent by May 2007, which currently represents 46.7 percent of total public spending. In addition, there was an increase of 18.3 percent in the health sector, and also an increase of 8.2 percent in education. Given the important role that public investment and poverty alleviation programs play in the government agenda, and as long as macroeconomic conditions allow absorption, higher-than-targeted levels of capital and targeted social expenditures will be supported.

12. As mentioned previously, one important achievement was the decrease in the public debt-to-GDP ratio, which reached $713 / 4$ percent in 2002 , mainly because of the large fiscal imbalances at that time and a depreciated currency which increased the burden of the debt. After an adequate fiscal adjustment effort, payments and arrears were regularized and the public debt burden was reduced to GDP to $271 / 2$ percent in 2006 . The government has stated that additional debt would be considered only in very favourable conditions.

13. With the objective to preserve stability in an intensive and important electoral moment for democratic consolidation, the fiscal and monetary authorities have launched an accord to which all socio-economic sectors are committed to contributing to guarantee a smooth transition and deliver to the next government (2008) a country with stronger institutions, less poverty, and a more stable economy in a context of a sustainable growth. A low and controlled inflation is a public good that affects the whole population. Therefore, coordination between fiscal and monetary policy will be the key purpose of this agreement.

\section{Monetary Policy}

14. The monetary authorities' key objective is to reach a core inflation of 5 percent by limiting currency growth to 12 percent, while maintaining control on net domestic assets 
around 20 percent by placements of LRM and holding an accumulation of 33 percent of currency in international reserves. Although core inflation was 7 percent at end-2006 and the 12-month rate of inflation fell to around 6 percent in April 2007, which is very auspicious, the monetary authorities think that it would be more prudent to establish a range between $2 \frac{1}{2}$ and $7 \frac{1}{2}$ percent for 2007 . Consistent with this objective and with an expected growth rate of 4-5 percent, as well as a moderate strengthening in real money demand, the Central Bank will maintain a reasonable level of growth of monetary aggregates.

15. During the first five months of 2007, Paraguay has experienced large inflows of foreign exchange, mainly from the royalties of the two bi-national hydroelectric plants, which has forced the Central Bank to make large purchases of foreign exchange in order to avoid a sudden appreciation of the currency - which in turn forced an increase in its placements of LRM to sterilize liquidity excess. Although the monetary authorities have significantly reduced LRM interest rates to discourage further inflows, there is still interest in these instruments, which indeed could facilitate the control of currency expansion by the Central Bank in the near future, as monetary costs would be lower.

16. Regarding the latter, it is important to mention that the monetary authorities are addressing the negative income position of the Central Bank and are currently designing a strategy to strengthen the financial position in coordination with the Ministry of Finance. Although this structural reform has taken longer than envisaged, the authorities would like to reiterate their commitment and the Ministry of Finance will prepare a legislation to send to Congress with the legal and budgetary strategy by September 2007. The resulting law will strengthen the Central Bank's financial position and guarantee improved monetary policy.

17. Although external vulnerabilities remain, the authorities are confident that the balance of payments will be kept under control, since against the current account deficit, the capital and financial account surplus in terms of GDP has more than doubled in 2006 and is projected to continue in this line. At the same time, the expected level of net international reserves is still strong, while the coverage remains around three months of imports. It is also expected that exports will continue to perform well, thanks to gains in productivity, namely beef and crops, especially soy, which is recovering after the drought.

\section{Financial and Structural Reforms}

18. Turning to the financial sector, the BNF has recovered as CAR surpassed the expected conditionality. In order to consolidate the BNF's financial position gained so far, the authorities intend to limit future political interference with the banks' lending policies and are developing a medium-term business strategy aimed to reduce operating costs, increase asset recovery, improve credit and risk management practices, and enhance internal controls.

19. Having missed the structural benchmark on implementing regulatory measures, the authorities have proposed three new supervision improvements. In this regard, the Central 
Bank will reach a consensus with the banking community on a new version of resolution $8 / 03$ to upgrade credit requirements, loan classification and provisioning. With assistance from the IMF, the Central Bank will design an ambitious plan to address weaknesses in the regulatory and supervisory frameworks of the banking system, which will aim to increase observance to around 80 percent of the Basel Core Principles of Banking Supervision. In addition, prudential regulations will be strengthened in critical supervising areas, such as capital requirements calculation, better rules for provisioning, streamlining administrative sanctions proceedings, rationalizing rules on open net foreign exchange positions and the public reporting on the financial position of banks.

20. An important and increasing portion of the financial system corresponds to cooperatives. Therefore, to reduce vulnerabilities and regulatory differences with the rest of the financial institutions, the supervisory institution INCOOP will develop an effective supervisory and regulatory framework for financial issues and will also strengthen the monitoring framework by compiling monetary statistics and its incorporation within the Central Bank's monetary statistics.

21. In order to facilitate transactions and mobilize financial resources, as well as improve the management of monetary policy and liquidity in the financial system, the Central Bank will prepare a draft payments system law to be approved by the economic cabinet by endSeptember 2007. In addition, although capital markets are in the early stages and with the intention to promote domestic savings and improve its allocation into productive investment projects, the Ministry of Finance, in coordination with the Central Bank, will design a strategy for the development of capital markets, which will consider legal and institutional demands.

22. Extreme poverty alleviation represents the authorities' main concern. In this vein, a cash transfer program to help families in extreme poverty has been implemented, which has reached over 8,800 families, more than its first objective of 7,000 families. This program primarily provides health and education services and the Ministry of Social Action, responsible for this coverage, intends to broaden it to 15,000 families by December 2007 .

23. The authorities are committed to moving forward with structural reforms with the aim of improving the business climate and promoting investment and growth. In this regard, the government agrees with the staff that an improvement in the investment climate will lead to a higher level of foreign and domestic investment; therefore, the Ministry of Industry would be implementing a master plan created to promote investment by September of this year.

\section{Closing Remarks}

24. Our authorities would like to thank the IMF for their support in consecutive programs and for their invaluable efforts and insightful advice. These programs have allowed Paraguay to set a firm commitment to crucial reforms. Most importantly, a solid and coordinated economic policy framework was (and still is) fundamental for economic recovery and 
poverty alleviation, while creating improved and favorable conditions through fiscal and monetary sectors to enhance productivity. At this stage, Paraguay is still facing important challenges that need to be addressed. However, the authorities are confident that cooperation with the Fund will be crucial to fulfill these endeavors. 
Public Information Notice (PIN) No. 08/71

FOR IMMEDIATE RELEASE

June 17, 2008
International Monetary Fund $70019^{\text {th }}$ Street, NW

Washington, D. C. 20431 USA

\section{IMF Concludes 2007 Article IV Consultation with Paraguay}

On June 29, 2007, the Executive Board of the International Monetary Fund (IMF) concluded the Article IV consultation with Paraguay. ${ }^{1}$

\section{Background}

After a decade of stagnation and instability, and a quarter of a century of declining living standards, Paraguay has experienced lately some of the best macroeconomic outcomes in recent history. Following the 2002 financial crisis and the implementation of economic reforms supported by the IMF under a Stand-By Arrangement approved in 2003 and renewed in 2006, growth has rebounded to almost twice its long-term average, per capita income increased to its highest level in 8 years, and the number of households living in extreme poverty was reduced by almost one third.

The economy is coming out of a long period of stagnation, as real GDP remained at about the same level during 1996-2002. The expansion that began in 2003 continued in 2006 with real GDP growth rising to about 4 percent, and prospects for strong growth in 2007 are good. On the supply side, growth was led by strong performances in services, stock farming and

\footnotetext{
${ }^{1}$ Under Article IV of the IMF's Articles of Agreement, the IMF holds bilateral discussions with members, usually every year. A staff team visits the country, collects economic and financial information, and discusses with officials the country's economic developments and policies. On return to headquarters, the staff prepares a report, which forms the basis for discussion by the Executive Board. At the conclusion of the discussion, the Managing Director, as Chairman of the Board, summarizes the views of Executive Directors, and this summary is transmitted to the country's authorities. This PIN summarizes the views of the Executive Board as expressed during the June 29, 2007 Executive Board discussion based on the staff report.
}

Washington, D.C. 20431 • Telephone 202-623-7100 • Fax 202-623-6772 • www.imf.org 
manufacturing. At the same time agricultural output began to recover as the effects of the previous years' drought began to taper off. On the demand side, growth was driven by a dynamic export sector, particularly beef, and a surge in private investment, especially in telecommunications.

Efforts to reduce inflation continued in 2006 with mixed results. While underlying inflation (excluding fruits and vegetables) was reduced from 10 percent in 2005 to 7 percent, headline inflation increased to $12 \frac{1}{2}$ percent. This increase reflected stricter application of sanitary controls on imports of vegetables, which reduced supplies and raised vegetable prices by almost 100 percent, and Paraguay's increased access to beef markets abroad, which pushed domestic beef prices up by over 30 percent. Supply shocks unwound in the first five months of 2007 , and the price level actually fell by about 1 percent. For the year as a whole inflation is expected to decline to 5 percent.

Public finances have improved considerably in the last few years, mainly on account of higher tax collections-supported by the 2004 tax reform-and efforts to rein in current spending. Public finances recorded a small surplus in 2006 ( 0.1 percent of GDP). Tax collections continued to be buoyant and current expenditures remained under control through the implementation of a strict financial plan, the freezing new positions (other than for social sectors), and the under-execution of capital expenditures.

The external position has been favorable in recent years, supported by a benign international and regional environment, and a reflow of previous capital flight. This allowed the Central Bank to triple its level of reserves over the last four years, to US $\$ 1.7$ billion by end-2006, and a 35 percent strengthening of the guarani against the U.S. dollar over the same period. During 2006, the external position improved significantly despite a deterioration of the current account-due to a surge in import demand—as the capital account continued improving. The external position strengthened further during the first part of 2007 and the level of reserves exceeded US $\$ 2.0$ billion at end-May.

\section{Executive Board Assessment}

Executive Directors agreed with the thrust of the staff appraisal. They commended the Paraguayan authorities for their continued implementation of sound macroeconomic policies, which have contributed to a rebound of economic growth and an increase in per capita income after a long period of stagnation. Prudent fiscal policies have put public debt on a sustainable path, and the build-up of international reserves in the context of a strengthened currency has enhanced Paraguay's resilience to external shocks. Directors encouraged the authorities to intensify reforms, especially in the financial sector, in order to entrench macroeconomic stability and establish the conditions for sustained growth and poverty reduction. 
Directors commended the authorities for their intention to achieve overall fiscal balance in 2007 and to implement the necessary budget cuts. Looking ahead, they stressed the need to maintain fiscal discipline in the face of intensifying pressures during the upcoming pre-electoral period. Directors underscored the importance of locking in last year's improvements in tax and customs administration and modernizing the tax code. They also saw a need for wage restraint and public sector rationalization to make room for more public investment. A strengthening of the budgetary framework would reduce the need to resort to financial plans, and would be a more effective and transparent means of expenditure control.

Directors supported the authorities' tight monetary policy stance, and encouraged them to persevere with their efforts to further reduce inflation. They considered that the Central Bank of Paraguay had struck a reasonable balance between accommodating currency appreciation and accumulating international reserves in the context of the country's floating exchange rate regime. Given the recent volatility of inflation rates, it will, however, be important to monitor the situation closely, and to respond promptly to any signs of underlying inflationary pressures or potential monetary imbalances. Directors encouraged early progress on steps to strengthen the financial position of the central bank.

Directors welcomed the improved soundness of Paraguay's banking system and strengthened confidence in the financial sector, as well as the decline in dollarization. Noting the setbacks that had occurred in 2006, Directors welcomed the authorities' renewed commitment to reinvigorate the reform momentum in this important area, and encouraged them to persevere with measures to strengthen commercial bank loan classification and provisioning requirements. Other financial sector reform priorities in the period ahead should include the development of a medium-term business plan for the publicly-owned development bank BNF, the preparation of a draft for a new payment system law, the formulation of a strategy to develop domestic capital markets, and the development of an effective supervisory and regulatory framework for financial cooperatives. Directors welcomed the steps to enhance compliance with the Basel Core Principles of banking supervision, and implement according to plan the central bank's prudential regulations.

Directors commended the authorities for taking a multi-pronged approach to structural reform, which will remain key to enhancing productivity and achieving higher economic growth on a sustainable basis. They encouraged them to maintain their commitment to implement the ambitious structural reform agenda in 2007 and over the medium term.

Regarding public sector reform, Directors welcomed the authorities' plans to draft implementing regulations for the tax procedures code, develop an action plan for pension reform, design a public investment system, and establish an expenditure control system at the commitment level. Implementation of the authorities' plan to improve the business climate will enhance the prospects for high growth. Public enterprises will be strengthened and the monitoring of their performance improved through the introduction of results-oriented contracts 
for their management. Directors also looked forward to steps to buttress the social safety net by broadening the coverage of the conditional cash transfer program and strengthening program evaluation mechanisms.

Public Information Notices (PINs) form part of the IMF's efforts to promote transparency of the IMF's views and analysis of economic developments and policies. With the consent of the country (or countries) concerned, PINs are issued after Executive Board discussions of Article IV consultations with member countries, of its surveillance of developments at the regional level, of post-program monitoring, and of ex post assessments of member countries with longer-term program engagements. PINs are also issued after Executive Board discussions of The staff report (use the free Adobe Acrobat Reader to view this pdf file) for the 2008 Article IV Consultation with the Republic of Croatia is also available.general policy matters, unless otherwise decided by the Executive Board in a particular case. 


\begin{tabular}{|c|c|c|c|c|c|c|c|}
\hline \multicolumn{8}{|c|}{ Paraguay: Selected Economic Indicators } \\
\hline & 2002 & 2003 & 2004 & 2005 & \multicolumn{2}{|c|}{2006} & 2007 \\
\hline & & & & & Prog. & Est. & Proj \\
\hline \multicolumn{8}{|c|}{ Annual percent change; unless otherwise specified } \\
\hline \multicolumn{8}{|l|}{ National accounts and prices } \\
\hline GDP at current prices & 10.0 & 22.5 & 16.4 & 11.2 & 13.1 & 12.7 & 10.6 \\
\hline GDP at constant prices & 0.0 & 3.8 & 4.1 & 2.9 & 3.5 & 4.0 & 4.0 \\
\hline Per capita GDP (U.S. dollars, thousands) & 0.9 & 1.0 & 1.2 & 1.3 & 1.4 & 1.6 & 1.9 \\
\hline GDP deflator & 10.0 & 18.0 & 11.8 & 8.1 & 9.2 & 8.3 & 6.3 \\
\hline Consumer prices (end-of-period) & 14.5 & 93 & 2.8 & 9.9 & $2.5-7.5$ & 12.5 & $2.5-7.5$ \\
\hline \multicolumn{8}{|l|}{ Real effective exchange rate $2 /$} \\
\hline Average (depreciation -) & -11.1 & -6.7 & 3.7 & -6.5 & & 12.5 & \\
\hline End-of-period (depreciation -) & -11.5 & 8.0 & -8.4 & 4.6 & & 16.7 & \\
\hline \multicolumn{8}{|c|}{ In millions of U.S. dollars } \\
\hline \multicolumn{8}{|l|}{ External sector } \\
\hline Exports, f.o.b. (percentage change) & -1.6 & 16.8 & 32.0 & 14.9 & 7.8 & 45.8 & 13.3 \\
\hline Imports, c.i.f. (percentage change) & -14.6 & 14.4 & 27.0 & 22.5 & 5.4 & 50.4 & 10.2 \\
\hline Current account & 93 & 125 & 139 & -26 & -180 & -14.1 & -146 \\
\hline (in percent of GDP) & 1.8 & 2.3 & 2.0 & -0.4 & -2.2 & -1.5 & -1.3 \\
\hline Capital account & 53 & 178 & 38 & 348 & 226 & 320 & 257 \\
\hline Overall balance & -81 & 211 & 270 & 130 & 46 & 402 & 244 \\
\hline Terms of trade (percentage change) & 3.0 & 1.5 & 0.0 & -15.6 & 4.3 & -8.4 & 4.8 \\
\hline \multicolumn{8}{|c|}{ In percent of GDP } \\
\hline \multicolumn{8}{|l|}{ Savings-investment balance } \\
\hline Gross domestic investment & 18.7 & 19.9 & 20.8 & 19.6 & 23.8 & 21.4 & 22.8 \\
\hline Private sector & 12.2 & 14.8 & 16.1 & 14.6 & 18.8 & 16.6 & 17.2 \\
\hline Public sector & 6.4 & 5.1 & 4.7 & 5.0 & 5.0 & 4.8 & 5.6 \\
\hline & & & & & & & \\
\hline Gross national savings & 20.5 & 22.2 & 22.8 & 19.2 & 21.6 & 19.9 & 21.5 \\
\hline Private sector & 18.3 & 17.6 & 16.3 & 13.4 & 16.7 & 14.8 & 15.9 \\
\hline Public sector & 2.2 & 4.6 & 6.5 & 5.8 & 4.9 & 5.1 & 5.6 \\
\hline \multicolumn{8}{|l|}{ Public sector } \\
\hline Central government primary balance & -1.9 & 1.0 & 2.7 & 1.9 & 1.0 & 1.5 & 0.9 \\
\hline Central government overall balance & -2.5 & -0.3 & 2.0 & 0.6 & 0.0 & 0.1 & 0.0 \\
\hline Consolidated public sector primary balance $1 /$ & -1.9 & 2.5 & 3.2 & 2.8 & 1.7 & 3.1 & 1.9 \\
\hline Consolidated public sector overall balance $1 /$ & -3.8 & 0.0 & 1.8 & 0.9 & 0.0 & 0.4 & 0.0 \\
\hline Public sector debt (end-of-year) 2/ & 71.7 & 52.6 & 45.1 & 37.7 & 34.1 & 27.5 & 25.4 \\
\hline External & 62.7 & 47.6 & 40.9 & 34.3 & 31.5 & 25.1 & 23.1 \\
\hline Domestic & 9.0 & 5.0 & 4.2 & 3.4 & 2.6 & 2.4 & 2.3 \\
\hline Consolidated public sector debt $3 /$ & 74.0 & 55.6 & 48.8 & 42.7 & 38.3 & 33.9 & 32.8 \\
\hline \multicolumn{8}{|c|}{ Annual percent change } \\
\hline \multicolumn{8}{|l|}{ Money and credit } \\
\hline Monetary base & -1.0 & 57.7 & 17.6 & 4.3 & 6.0 & 13.0 & 11.1 \\
\hline M2 & -2.2 & 24.9 & 24.6 & 16.1 & 8.5 & 15.3 & 12.0 \\
\hline M5 3/ & -185 & 17.7 & 11.7 & 7.7 & 8.2 & 7.9 & 11.9 \\
\hline Credit to the private sector $4 /$ & -20.9 & -18.4 & 13.9 & 14.1 & 11.9 & 6.8 & 6.3 \\
\hline Velocity of M2 & 7.5 & 8.3 & 7.7 & 7.2 & 7.2 & 7.0 & 6.8 \\
\hline \multicolumn{8}{|l|}{6.8} \\
\hline \multicolumn{8}{|l|}{ Memorandum items: } \\
\hline International reserves (in millions of U.S. dollars) & 641 & 983 & 1,168 & 1,297 & 1,317 & 1,703 & 1.920 \\
\hline (In months of imports) & 2.8 & 3.5 & 3.4 & 2.5 & 3.6 & 3.0 & 3.2 \\
\hline GDP (in billions of guaranies) & 29,105 & 35,666 & 41,522 & 46,169 & 52,156 & 52,020 & 57,520 \\
\hline \multicolumn{8}{|c|}{ Sources: Paraguayan authorities; and Fund staff estimates. } \\
\hline \multicolumn{8}{|c|}{$\begin{array}{l}\text { 1/ Consolidated public sector, including the quasi-fiscal operations of the BCP. } \\
\text { 2/ Nonfinancial Public Sector. Based on end-of-period exchange rate conversion of U.S. dollar-denominated debt. } \\
\text { 3/ Includes Central Bank Bills (LRMs). } \\
\text { 4/ Foreign currency items are valued at a constant exchange rate. }\end{array}$} \\
\hline
\end{tabular}


